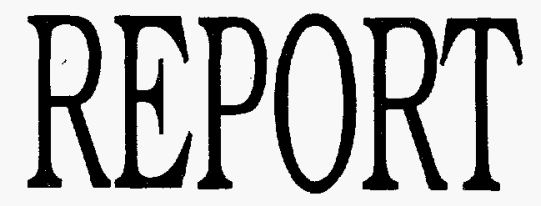

BCLDP-063095

\title{
BCLDP
}

\section{Site Environmental}

Report for Calendar

\section{Year 1994}

on Radiological

and Nonradiological

\section{Parameters}

To

U.S. Department of Energy

DOE Operations Office, Chicago

June 30, 1995

by: Safety, Health and Environmental Support 


\title{
Site Environmental Report for Calendar Year 1994
}

on

\section{Radiological and Nonradiological Parameters}

\author{
to
}

\section{United States Department of Energy DOE Field Office, Chicago}

\section{June 30, 1995}

$$
\text { by }
$$

Safety, Health and Environmental Support Battelle Columbus Laboratories Decommissioning Project
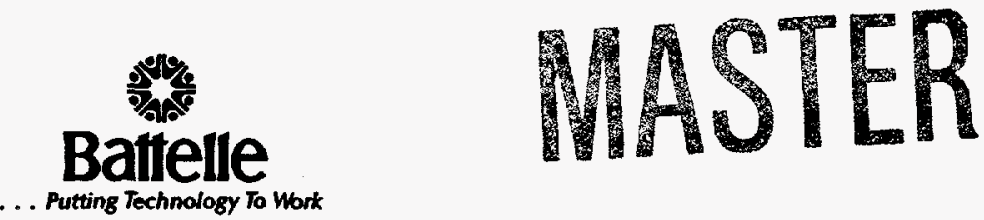


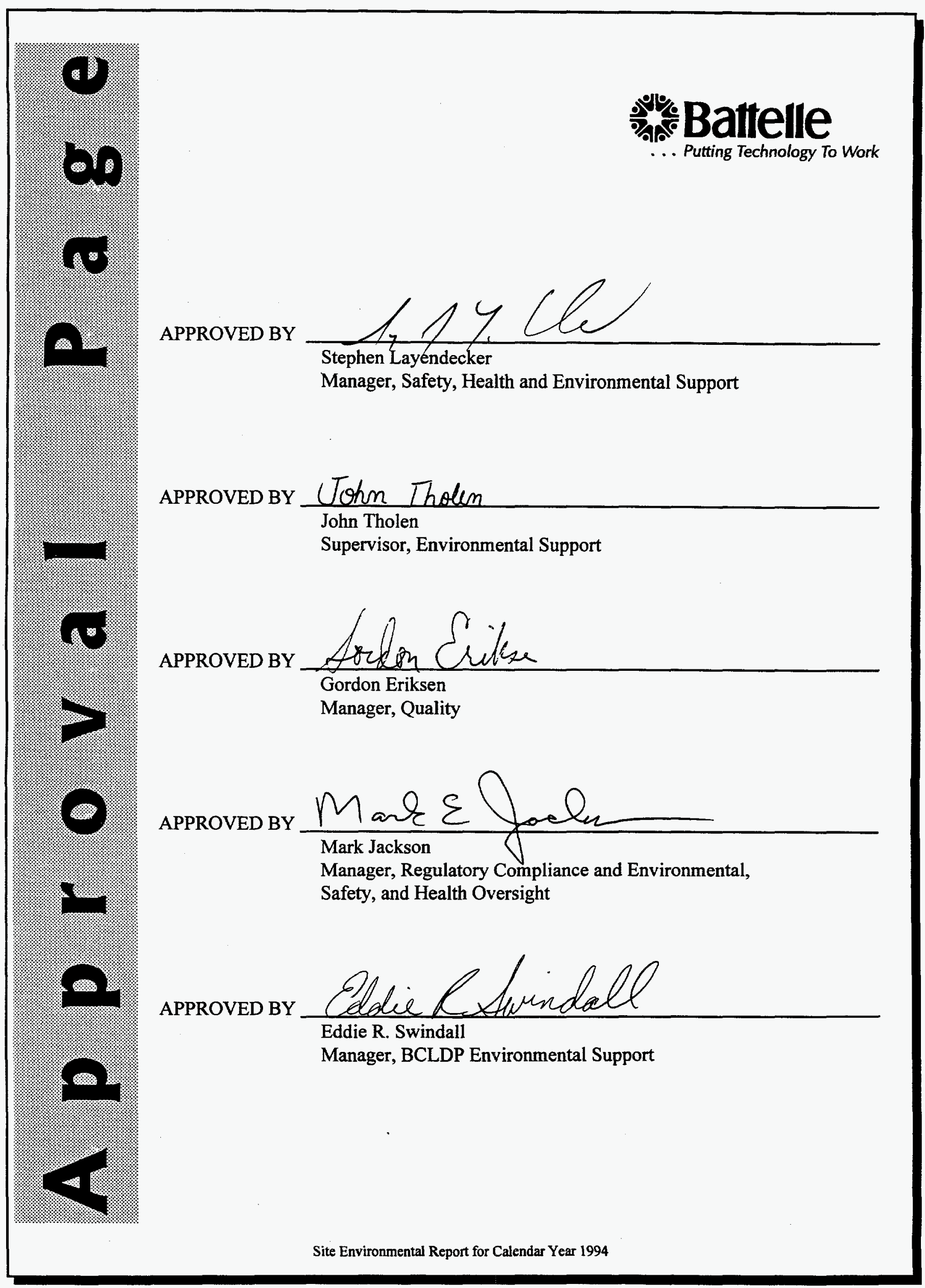




\section{DISCLAIMER}

Portions of this document may be illegible in electronic image products. Images are produced from the best available original document. 


\title{
FOREWORD
}

This report was prepared for the Battelle Columbus Laboratories Decommissioning Project $(B C L D P)$ by staff in the Safety, Health and Environmental Support Group for submission to the U.S. Department of Energy (DOE). The radiological monitoring data were supplied by environmental and operational health physics staff. Radioanalyses of environmental air, water, grass, soil, sediment, and field and garden crop samples were performed by the BCLDP Radioanalytical Laboratory except for certain plutonium, strontium, thorium, and uranium analyses performed by Quanterra Corporation in St. Louis, Missouri, and Ecotek, Inc., Atlanta,
Georgia. Thermoluminescence dosimeter analyses were performed by Landauer, Inc., Glenwood, Illinois and Siemens Medical Systems, Hoffman Estates, Illinois. Non-radiological analyses of environmental water samples were performed by Burgess \& Niple Laboratory, Columbus, Ohio, the Columbus Water and Chemical Testing Laboratory, Columbus, Ohio, and Kemron Environmental Services, Marietta, Ohio.

An environmental compliance summary is included for the calendar year (CY) 1994. The summary includes environmental statutes, regulations, and DOE Orders.

\section{DISCLAIMER}

\begin{abstract}
This report was prepared as an account of work sponsored by an agency of the United States Government. Neither the United States Government nor any agency thereof, nor any of their employees, makes any warranty, express or implied, or assumes any legal liability or responsibility for the accuracy, completeness, or usefulness of any information, apparatus, product, or process disclosed, or represents that its use would not infringe privately owned rights. Reference herein to any specific commercial product, process, or service by trade name, trademark, manufacturer, or otherwise does not necessarily constitute or imply its endorsement, recommendation, or favoring by the United States Government or any agency thereof. The views and opinions of authors expressed herein do not necessarily state or reflect those of the United States Government or any agency thereof.
\end{abstract}




\section{--THIS PAGE INTENTIONALLY LEFT BLANK--}




\section{Contents}

Foreword

Executive Summary

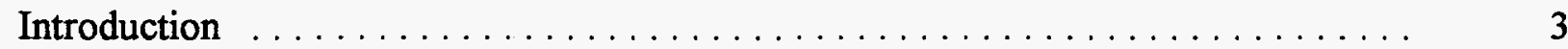

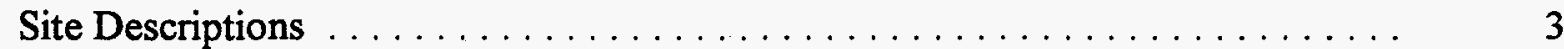

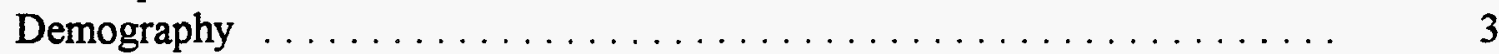

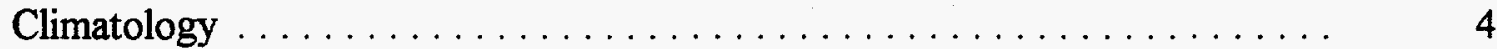

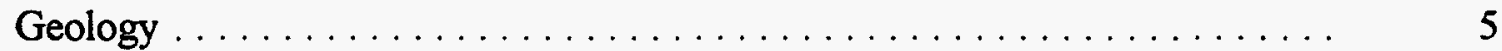

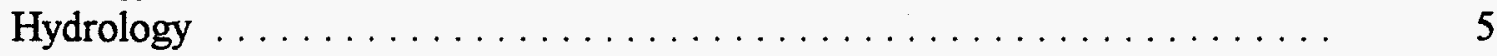

Background Radiological Characteristics .................... 6

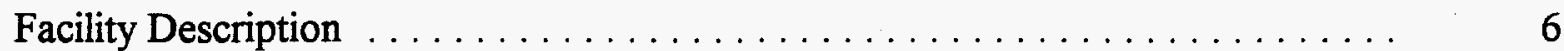

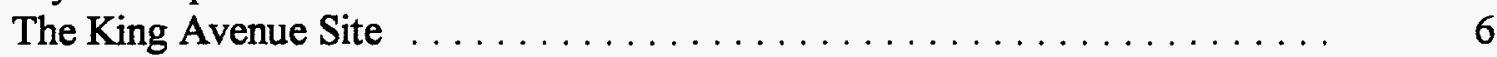

The West Jefferson Site $\ldots \ldots \ldots \ldots \ldots \ldots \ldots \ldots \ldots \ldots \ldots \ldots \ldots \ldots$

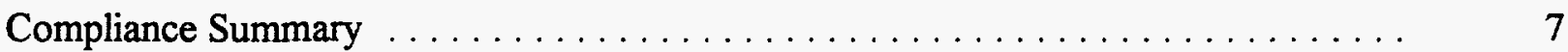

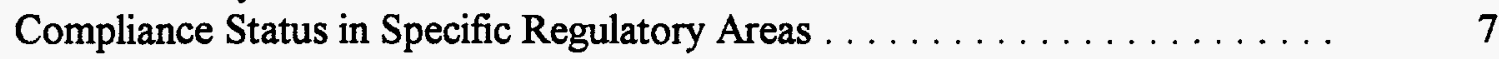

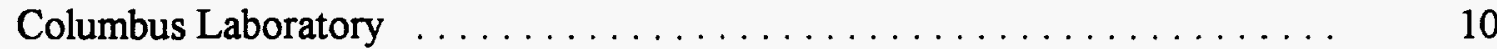

West Jefferson Laboratory . . . . . . . . . . . . . . . . . . . . . 10

Environmental Program Information $\ldots \ldots \ldots \ldots \ldots \ldots \ldots \ldots \ldots \ldots \ldots \ldots$

Environmental Radiological Monitoring $\ldots \ldots \ldots \ldots \ldots \ldots \ldots \ldots \ldots \ldots, 12$

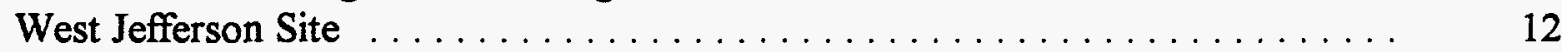

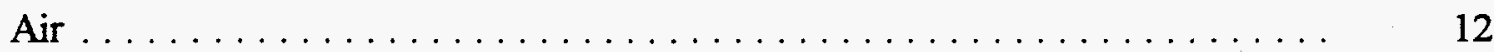

Water......................................... 13

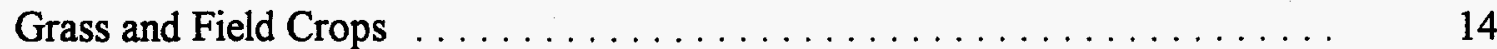

Garden Crops . . . . . . . . . . . . . . . . . . . . . . . . . . 14

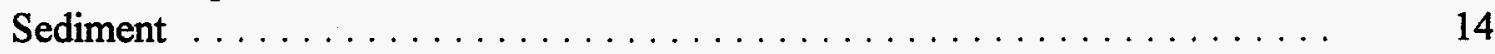

Soil ........................................ 14

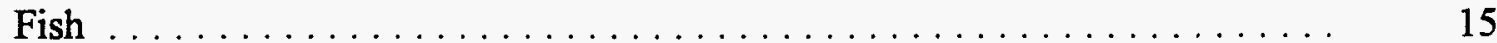

Background Radiation Levels . . . . . . . . . . . . . . . . . . . . . 15

Fence Post Dose Estimate $\ldots \ldots \ldots \ldots \ldots \ldots \ldots \ldots \ldots \ldots \ldots \ldots \ldots$

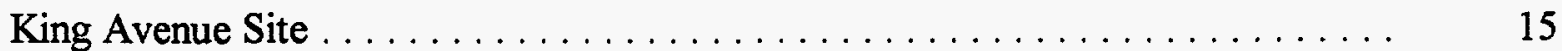

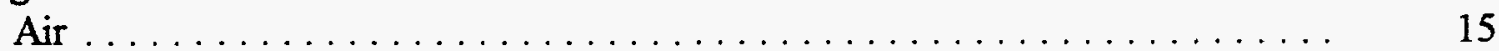

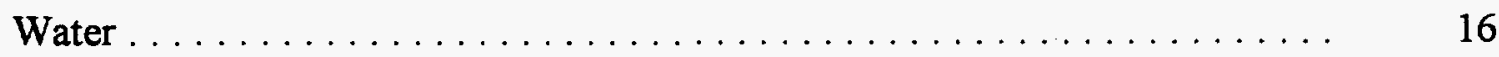

Soil ........................................ 16

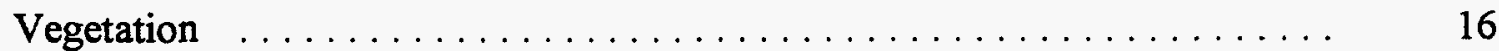

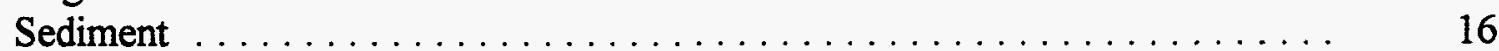

Water . . . . . . . . . . . . . . 17

Fish ...................................... 17

Direct Radiation Measurement . . . . . . . . . . . . . . . . . . . . . . . . . 17 


\section{Contents (Continued)}

Page

Environmental Nonradiological Program Information

Groundwater Monitoring and Protection Program $\ldots \ldots \ldots \ldots \ldots \ldots$

Evaluation of Dose to the Public

Estimated Dose to the Public from the King Avenue Site

Emissions During 1994

Estimated Dose to the Public from the West Jefferson Site

Emissions During 1994

Atmospheric Discharges

Liquid Discharges ...

Calculation of Atmospheric Dispersion Parameters

Computation of Dose Equivalent Rates to Nearby

Individuals and Population Groups

Quality Assurance

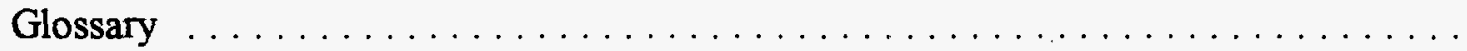

References

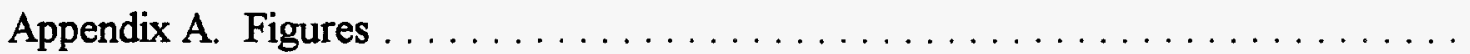

Appendix B. Tables

B-1

Appendix C. Environmental Report External Distribution List

C-1 


\section{Executive Summary}

B attelle Memorial Institute's nuclear research facilities are currently being maintained in a surveillance and maintenance (S\&M) mode with continual decontamination and decommissioning (D\&D) activities being conducted under Department of Energy (DOE) Contract W-7405-ENG-92. These activities are referred to under the Contract as the Battelle Columbus Laboratories Decommissioning Project (BCLDP). Operations referenced in this report are performed in support of S\&M and D\&D activities. Battelle's King Avenue facility is not considered in this report to the extent that the West Jefferson facility is. The source term at the King Avenue site is a small fraction of the source term at the West Jefferson site. The contamination found at the King Avenue site consists of small amounts of residual radioactive material in solid form, which became embedded or captured in nearby surfaces such as walls, floors, ceilings, drains, laboratory equipment and soils. This "fixed contamination" is the vast majority of material associated with the BCLDP at King Avenue. Minimum detectable quantities of isotopes suspected, but not identified in samples, are listed in the Annual Radionuclide Release Inventory for Battelle. Suspected isotopes are those expected to be found in the residual contamination left from previous nuclear fuel work.

No isotopes were present above minimum detectable levels (MDL) for liquid discharges to Big Darby Creek from the West Jefferson Nuclear Sciences Area or for air releases. Data obtained from downstream sampling locations were statistically indistinguishable from background levels. MDL values for specific isotopes not detected were used to determine the percentage of the respective DOE 5400.5 derived concentration guide (DCG) values for an individual radionuclide released to an unrestricted area.

Radionuclide emissions emanating from BCLDP operations conducted at the King Avenue and the West Jefferson sites were compliant with the Section 61.102 dose standard and exempt from the Section 61.104 reporting requirements cited in 40 CFR 61 Subpart I for calendar year (CY) 1994. Dose assessments were performed using both the COMPLY and the CAP88PC air dispersion modeling computer programs. Calculations derived from the COMPLY model assessed an Effective Dose Equivalent (EDE) to the public at the King Avenue site at $8.2 \times 10^{-3}$ mrem/year. A $7.40 \times 10^{-4} \mathrm{mrem} /$ year EDE was assessed to the public for radionuclide emanating from BCLDP operations located at the West Jefferson site. In comparison, the CAP88PC modeling computer program calculated an EDE to a critical receptor located adjacent to the West Jefferson site at $2.09 \mathrm{x}$ $10^{-3} \mathrm{mrem} /$ year. Insufficient data were available for dose assessments to be calculated using the CAP88PC model for radionuclide emissions emanating from the King Avenue site because the KA-3 Central Staging Area exhaust vents were dismantled early in CY 1994. Radioanalyses of air filters collected from the site perimeter Environmental Air (EA) samplers indicate that radionuclide concentrations were significantly below the maximum allowable concentration values cited in 10 CFR 20, Appendix B, Table 2, and the DCG values.

West Jefferson nuclear operations during 1994 caused no distinguishable impact on concentrations of airborme radionuclides or on external radiation doses measured adjacent to the West Jefferson Nuclear Sciences area and the Battelle site boundary. The whole body "fence-post" exposure during 1994 for external radiation at the site boundary was at background levels for Camp Ken Jockety, the Girl Scout camp located approximately $0.4 \mathrm{~km}$ (1,312 ft.) northeast of the West Jefferson North site boundary. An estimated dose of $120 \mathrm{mrem} / \mathrm{yr}$ was verified through the use of thermoluminescence dosimeters (TLDs) placed at fixed locations around the site boundary. This dose value is the same as the national average for total background radiation. A discussion of how the "fence-post" exposure was determined is presented in the section titled, Environmental Radiological Monitoring for the West Jefferson Site.

The values reported for uranium isotopes are recorded in units of Curie (Ci) and gram ( $\mathrm{g}$ ) as per requirements of DOE Order 5400.5, Radiation Protection of the Public and the Environment. Conversion factors for the calculations performed for the reported values were obtained from 10 CFR Part 20, Standard for Protection from Radiation. Off-site levels of radionuclides that could be attributed to the West Jefferson and King Avenue nuclear operations were 
indistinguishable from background levels at specific locations where air, water, and direct radiation measurements were performed.

Environmental monitoring continued in order to demonstrate compliance by Battelle with federal, state, and local regulations. Routine, nonradiological activities performed in association with the BCLDP include monitoring liquid effluents under the direction of the National Pollutant Discharge Elimination System (NPDES) Permit, 4IN00004*DD and monitoring the groundwater system for the West Jefferson North site. Groundwater wells are the source of potable water for the West Jefferson area and city water is the source of potable water for the King Avenue area.
In addition to routine monitoring of liquid and atmospheric emissions at the King Avenue and West Jefferson Nuclear Sciences Area, samples of various environmental media including air, water, grass, fish, field and garden crop, sediment, and soil were collected from the region surrounding the two sites and analyzed. The environmental sampling activities were performed in accordance with standard operating procedures established by Battelle's Environmental Monitoring Program.

$D \& D$ activities during the year involved site and building characterization at West Jefferson, and room and/or building characterization at King Avenue with actual decontamination and decommissioning primarily performed in Building 3 and Building 4 at the King Avenue site as well as in Buildings 1, 2, 5, 6, 7 , and A. Decontamination of Building 3 at King Avenue was completed in September 1994. 


\section{Introduction}

0 n April 16, 1943, Battelle Memorial Institute, a private non-profit organization, entered into Contract No. W-7405-ENG-92 with the Manhattan Engineering District to perform atomic energy research and development activities. Since that time, Battelle has continuously performed research and development work under the contract at its facilities for the United States Department of Energy (DOE) and its predecessor agencies. Surveillance and maintenance (S\&M) and decontamination and decommissioning (D\&D) activities performed for DOE under this contract, Memorandum of Understanding, dated August 14, 1986, were conducted at its King Avenue and West Jefferson facilities during CY 1994. Some Nuclear Regulatory Commission (NRC) licensed activities were also conducted at both sites, but are not addressed specifically in this report. This report makes no distinction between effluents that may result from contracted or licensed activities.

\section{Site Descriptions}

The relationship between the Battelle King Avenue site and the Nuclear Science Area at the West Jefferson site is illustrated in Figure $1^{*}$, which represents a regional map covering an $80-\mathrm{km}$ (50mile) radius.

The Battelle King Avenue facility is located at $39^{\circ} 59 \mathrm{~N}, 83^{\circ} 03^{\prime} \mathrm{W}$ in the western central portion of Columbus, Ohio. The 58.3-acre plot, accommodating 21 buildings, is bounded on the north by King Avenue, Battelle Boulevard and Perry Street to the east, by Third Avenue to the south, and the Olentangy River to the west. Figure 2 shows the property boundary of the Battelle King Avenue site. It indicates the location of Building 3, which housed facilities formerly used in uranium handling. During 1994, decontamination and decommissioning (D\&D) activities were also conducted in Buildings 1, 2, 4,5, 6,7 , and $\mathrm{A}$.

The West Jefferson site (Figure 3 ) is located at $39^{\circ} 58 \mathrm{~N}, 83^{\circ} 15^{\prime} \mathrm{W}$, approximately 15 statute miles west of the King Avenue facility. The West Jefferson site consists of a 1,000-acre tract that accommodates

*Figures are located in Appendix A of this document. the Engineering Area in the southeastern portion, the Middle Area in the east central portion, and the Nuclear Sciences Area in the northern portion. The northern boundary of the site lies approximately onehalf mile south of Interstate Highway 70 and extends from the Georgesville-Plain City Road eastward to the Big Darby Creek. The eastern boundary of the site roughly parallels the valley of the Big Darby Creek southward to the Conrail tracks, which constitute the southern boundary. The Georgesville-Plain City Road defines the western boundary of the site.

For this report, the focus of interest is the Nuclear Sciences Area at the West Jefferson site, which is indicated by the shaded area of Figure 3 . The Nuclear Sciences Area consists of a 10-acre fenced area enclosing a guardhouse, four buildings, and two other small structures on a flat bluff; Battelle Lake lies to the south and Big Darby Creek lies to the east. The eastern edge of the bluff drops rather abruptly from an average elevation of 910 feet to 870 feet mean sea level (MSL), then more gradually to the 860-foot elevation of the Big Darby Creek floodplain. Battelle property extends to the north, west, and south. Some land is leased to farmers, typically for raising field crops such as corn or soybeans. The site includes two narrow wooded strips, one along the northern portion of the fence around the Nuclear Sciences facility, and the other approximately 1,000 feet to the northeast from the center of the site: To the east, within the Big Darby floodplain and along the bluffs to the east of the Creek, the land is heavily vegetated with deciduous trees, shrubbery, and high grasses.

\section{Demography}

The King Avenue site is located east of State Route 315 and is bordered by Battelle Boulevard and Perry Street to the east, King Avenue to the north, Third Avenue to the south and the Olentangy River to the west. The area within two miles of the King Avenue site to the east and south consists of predominantly single-family urban residential neighborhoods. The Near Northside Historic District, listed on the National Register of Historic Places, encompasses these neighborhoods. A small portion of the King Avenue site is located within the Near Northside Historic District. No research buildings are included in this district, however, this portion does include land owned by Battelle from Fifth Avenue south to Third Avenue. 
The area to the east and north of the King Avenue site, north of Fifth Avenue, is within the city's University District. The Ohio State University, with a student enrollment of approximately 50,000 and a staff of approximately 29,000 , is adjacent to the King Avenue site on the north. The Olentangy River borders the west boundary of the King Avenue site. The area west of the Olentangy River consists mainly of small business and light industrial properties, with scattered residential patches. Table 1"*, Battelle King Avenue Site Population Within 50-Mile Radius, includes data on the population distribution within a 50-mile radius of the King Avenue facility, based on 1990 census data prepared by the Ohio Department of Development.

The area immediately adjacent to the West Jefferson site has a low population density. Table 2, Battelle West Jefferson Site Population Within 50-Mile Radius, gives the population distribution, by direction and distance, within 50 miles of the Battelle West Jefferson site. Camp Ken Jockety, a Girl Scout camp, is located on a bluff on the east side of the Big Darby Creek with the western boundary of the camp at a distance of 1,640 feet from the center of the West Jefferson site and a residence within the camp located approximately 3,300 feet from the center of the Battelle site. The residences nearest to the Nuclear Sciences Area are in Lake Darby Estates. This subdivision is located approximately 2,500 feet southeast of the site boundary on the eastern side of the Big Darby Creek, and consists of 965 single family units (Figure 3). A second subdivision, West Point, located east of Lake Darby Estates and Hubbard Road, has approximately 540 housing units.

The primary agricultural activity in the area is raising field crops such as corn and soybeans. Approximately 10 percent of the land area in agricultural use is devoted to pasturing beef cattle.

Two major highways, I-70 and I-270, are near the West Jefferson site. The junction of these highways, which lies near the eastern edge of the 10-mile perimeter around the Nuclear Sciences Area, has proven to be a popular area for commercial growth. It is estimated that the commercial population has shown an increase equivalent to that of the general population in this area, i.e., two and one-half times the 10-mile population distribution for 1965 .

\footnotetext{
${ }^{* *}$ Tables are located in Appendix B of this document.
}

\section{Climatology}

Climate for the West Jefferson and King Avenue sites is typical of the south-central Ohio region. Climatology of this region may be described as continental-temperate. As such, the region is subject to a wide seasonal range in temperature. Summers are quite warm; the mean temperature for the months of June, July, and August is $73.3 \mathrm{~F}$. Temperatures of $90 \mathrm{~F}$ or above are expected for about 15 days during these months. The mean for the months of December, January, and February is $31.2 \mathrm{~F}$. The number of days per year with temperatures below $32 \mathrm{~F}$ and below $0 \mathrm{~F}$ are 122 and 4 , respectively.

Precipitation is distributed fairly uniformly during the year, although 60 percent falls during the spring and summer seasons. The annual, average monthly rainfall is approximately 3.5 inches. The greatest recorded rainfall for any 24-hour period was 5.16 inches in July of 1992.

Changeable wind directions are characteristic of the region because of the incursion of maritime tropical air masses from the Gulf of Mexico and outbreaks of continental polar air masses from Canada. Warm air mass inversion is most common during the late spring and summer and frequently results in frontal showers and thundershowers. Tropical air mass thunderstorms are also common during the summer and are frequently accompanied by high winds. Additionally, it is not uncommon for hot air mass thunderstorm development to be sufficiently strong enough to spawn tornado activity. Cold fronts that invade the region, principally during the late fall, winter, and early spring, also bring showers and thunderstorms.

During the late spring, fast-moving cold fronts, with large temperature discontinuities ahead of and behind the frontal surface, travel through the region and are often accompanied by thunderstorms and frequently by tornado activity. Of the 567 tornadoes recorded within 144 miles of the Battelle facilities during the period 1950-1975, 163 have occurred in the month of April.

The regional climatological data gathered by the National Weather Service at Port Columbus, seven miles east-northeast of the King Avenue facility, are generally representative of the local climatic conditions at the Columbus site. Data from Port Columbus are used to prepare wind rose patterns and tables of average wind speed and direction. Detailed 
meteorological data for the Columbus, Ohio area are also included in the air model (CAP88-PC) used to prepare this Site Environmental Report.

\section{Geology}

The arrangement of geological strata underlying the West Jefferson and King Avenue areas consist of glacial till and outwash with formations of clay, sands, and gravel. The sands and gravel of the outwash are found in scattered, thin, discontinuous lenses within the till, which is composed of unstratified clay containing fragments of rock. The unglaciated basement formations in the West Jefferson area lie at depths ranging from approximately 80 to 100 feet below the surface. The formations consist of nearly horizontal beds of limestone, dolomite, and shale several hundreds of feet thick. Surface soils consist of patches and mixtures of Brookston silty clay loam, Crosby silt loam, Lewisburg silt loam, Celina silt loam, and Miamian silt loam. The greatest portion of surface soils is represented by the Brookston-Crosby Association with little more than traces representing the remaining types. These soil types exhibit relatively low permeability; and grade into till clay at depths of 55 to 60 inches where the impermeability of the nearsurface geology greatly impedes further percolation.

No recorded earthquakes have occurred within 50 miles of the area of interest, although in 1937 a strong quake was experienced at Anna, Ohio, located approximately 50 miles northwest of the West Jefferson site. The Columbus-West Jefferson areas are, however, considered to be in a nonseismic region. The Battelle facilities are in a Universal Building Code (UBC) Seismic Zone 1 low-risk area.

\section{Hydrology}

Two aquifers, or underground sources of water, are located in the West Jefferson site area. The shallow aquifer is located in the dense clay till and the deep or principal aquifer is located in the limestone bedrock underlying the till. Earlier wells in the site area ranged in depth from 10 to 40 feet, which placed them in the glacial deposits. Till is not very permeable and yields water slowly. The effective velocity of water moving through clay under a hydraulic gradient of one percent is reported to be less than 0.004 foot per day; for water moving through silt, sand, and loess under the same gradient, the rate is between 0.0042 and 0.065 foot per day. Water movement in the till at the Battelle site is estimated to be within the range of the former figure, since the hydraulic gradient of the water table in the area is only slightly greater than one percent.

The current supply wells at the Battelle West Jefferson facility lie below the surface of the bedrock. The north well is $\mathbf{1 3 0}$ feet deep, the centrally located well in the Middle area is 162 feet deep, and the South area well is 138 feet deep. Bedrock was encountered at approximately 103 feet below the surface while drilling these wells. The source of groundwater in the site area is local precipitation. Recharge to the shallow aquifer takes place relatively uniformly over the area. Contours of the water table, which are approximately 40 feet below the surface, are a subdued reflection of the surface topography. Groundwater moves downslope at right angles to the contours and follows a path similar to surface runoff. At the Nuclear Sciences Area surface runoff moves downslope into the lake, then through the controlled dam on the site into Big Darby Creek.

A man-made hydrologic feature of the site is the artificial lake. It covers an area of about 25 acres and was formed by damming Silver Ditch southeast of and down gradient from the Nuclear Sciences Area. The normal surface elevation of the lake is $\mathbf{8 8 8}$ feet above mean sea level (MSL).

Test borings drilled in 1970 for an addition to the Hot Cell Laboratory (discussed in the Facility Description section) reaffirmed the geology described above. Only isolated pockets of groundwater were encountered during boring and foundation-piling excavation operations. These pockets were readily pumped out and remained dry, which indicated that there is no interconnection between the groundwater pockets and the lake.

Flood water calculations for the lake measured during the January 1959 floods indicate a release rate for water that is about three times the inflow rate. It is concluded that the lake has not adversely affected the hydrology of the area.

Big Darby Creek accounts for the principal surface water flow. The Darbyville gauging station is the only continuous recording gauge on Big Darby Creek. It is located 40.46 river miles south of the West Jefferson facility. Normal flow, recorded at Darbyville, is 430 cubic feet per second (cfs). 


\section{Background Radiological Characteristics}

Radiation occurs from sources found in nature, as well as from man-made sources. The four primary sources of natural radiation are: cosmic radiation emitted from the sun and outer space; terrestrial radiation resulting from the decay of radioactive elements in the earth; the decay of naturally occurring elements in the human body and; radon and its daughter products resulting from the decay of uranium and thorium in rocks and soil.

In the United States, these natural sources of radiation produce an average dose of approximately $300 \mathrm{mrem}$ per year. ${ }^{(2)}$ Of this number, approximately 55 percent or $162 \mathrm{mrem} /$ year comes from radon. In 1966, the natural terrestrial background for the region surrounding Battelle was measured to be 60 mrem/year by an aircraft equipped with radiation instrumentation. ${ }^{(3)}$ This number is greater than the national average of approximately 29 mrem/year. ${ }^{(2)}$ The cosmic background for the State of Ohio is averaged to be $50 \mathrm{mrem} / \mathrm{year}$, compared to a U.S average of $29 \mathrm{mrem} / \mathrm{year} .{ }^{(2)}$ The estimate for internal emitters within the body is considered to be approximately $40 \mathrm{mrem} / \mathrm{year}$ for the United States with only minor regional variations. ${ }^{(2)}$ As indicated in the section entitled Evaluation of Dose to the Public, the impact from Battelle's atmospheric discharges from operations is significantly less than $1 \mathrm{mrem} /$ year.

\section{Facility Description}

The center of D\&D activities at the Battelle King Avenue site during 1994 was the former U-235 handling facility, located on the first floor of Building 3. It was the nuclear materials management point for all transactions involving nuclear material at the King Avenue site. Figure 4 shows the location of Building 3 at the King Avenue site building complex.

At the West Jefferson Nuclear Sciences Area, the major S\&M operations are the result of research and development (R\&D) on the properties of irradiated materials. This work was performed in the Hot Cell Laboratory (JN-1) and involved examination and testing of irradiated reactor fuel, nuclear pressure vessel material, and fuel cladding material. Only residual fuel contamination and small contained sources remain onsite. Nuclear support and S\&M activities are conducted in the Administrative Building (JN-2) and the retired Battelle Research Reactor
(JN-3). Figure 5 shows the locations of these nuclear facilities in the Nuclear Sciences Area building complex.

The D\&D activities that occurred during the year involved site and building characterization at West Jefferson, room and/or building characterization at King Avenue, and the actual D\&D of Buildings 3 and 4 , and to some extent Buildings 1, 2, 5, 6, 7 and $A$ at the King Avenue site.

\section{The King Avenue Site}

The former U-235 handling facility is located in Building 3 of the King Avenue site. This facility was constructed in the mid-1950s. It served until the late 1960s as an exclusion area specifically designed for the control and storage of unirradiated enriched uranium utilized on various government and industrial R\&D programs. Building 3 was also used for several other BCLDP activities, including waste storage and characterization. Access to the U-235 area was limited and entry doors to the area were locked. A vault was used for the temporary storage of limited quantities of unirradiated enriched uranium. The U-235 area also served as a receipt and shipping, sampling, and measurement area for shipments of source materials and small quantities of unirradiated uranium that had been used on programs performed at the King Avenue site. Decontamination of Building 3, including the U-235 area, was completed in September 1994.

\section{The West Jefferson Site}

Figure 5 shows the location of the four principal buildings at the West Jefferson Nuclear Sciences Area: the Hot Cell Laboratory (JN-1); the Administrative Building (JN-2); a retired Research Reactor ( $\mathrm{NN}-3$ ); and the Hazardous Material Research Facility (Decommissioned Plutonium Laboratory) (JN4). Each of these facilities is described in the following paragraphs.

\section{Hot Cell Laboratory, $J N-1$}

The Hot Cell Laboratory contains approximately 22,000 square feet of space. It was considered to be one of the most completely equipped installations available to the nuclear community. The Hot Cell Laboratory was capable of providing research and technical assistance in the following areas: 
- Power reactor fuel performance evaluations

- Pressure vessel irradiation surveillance, and capsule examinations and evaluations

- Postirradiation examinations of nuclear materials and components

- Radiation source encapsulation

- Physical and mechanical property studies of irradiated materials and structures.

The Hot Cell Laboratory consists of a large, highenergy cell with connected fuel handling pool, five smaller cells, and supporting facilities. The highenergy cell and pool are capable of handling complete power reactor fuel assemblies. The smaller cells consist of the high-level and low-level cells, the two mechanical test cells, and a segmented alpha gamma cell. The supporting facilities include areas for cask handling, solid and liquid-waste disposal, contamination control, equipment decontamination, and other miscellaneous operations. All of these operations have contributed to the need for S\&M activities while awaiting decommissioning.

\section{Administrative Building, $J N-2$}

This Administrative Building was designed and constructed for use as a critical assembly laboratory. It was used for critical experiments from 1957 through 1963. Since the cessation of critical experiments, the facility has been used for several nuclear-related projects, including direct conversion concepts, irradiation experiment assembly, and special nuclear materials (SNM) handling. The operating license was terminated by Battelle in 1970 when project work was ended. These activities have made it necessary to maintain this area on the S\&M schedule.

Offices and small laboratories are used by nuclear supporting services staff including the Environmental Monitoring, Quality Assurance, Instrument Maintenance, and a Radioanalytical Laboratory for the assay of routine health physics and environmental sampling activities. The bulding also housed a vault used for storage of SNM through May of 1994. The remaining SNM were moved to another location during May and the vault was cleared for alternative uses.

\section{Retired Battelle Research Reactor, $I N-3$}

The Battelle Research Reactor began operation on October 29, 1956. Operations were terminated on December 31, 1974, and dismantling was initiated. The dismantling was completed without incident during 1975 and Battelle's license was changed to a possession only status. Storage of waste awaiting shipment for burial is the principal licensed activity conducted in $\mathrm{NN}-3$ at this time.

\section{Decommissioned Plutonium Laboratory, $J N-4$}

Building JN-4 was built in 1960 to house activities for plutonium research and processing. These activities were terminated in 1978 and the laboratory portion was dismantled in 1985. A hazardous materials research facility which now operates in $\mathrm{N}-4$ involves only nonradioactive materials.

\section{Compliance Summary}

$\mathbf{T}$ he BCLDP strives to maintain a state of compliance with applicable environmental statutes, regulations and DOE orders. No fines, penalties, or administrative orders were imposed on BCLDP during 1994 or the first quarter (January 1 through March 31) of 1995 . No lawsuits by regulatory agencies or citizen suits were brought against Battelle, and there were no EPA-cited BCLDP compliance issues in 1994 or the first quarter of 1995. There were no unresolved BCLDP compliance issues during 1993 that needed to be addressed in 1994. If there are any unresolved compliance issues in 1994, they will be addressed in the 1995 Site Environmental Report.

\section{Compliance Status in Specific Regulatory Areas}

\section{Comprehensive Environmental Response, Compensation and Liability Act (CERCLA)}

No violations have occurred and no enforcement actions under CERCLA were taken in connection with the BCLDP. There were no releases of hazardous substances that required notification under CERCLA. 
Resource Conservation and Recovery Act (RCRA)

No violations have occurred and no enforcement actions under RCRA were taken in connection with the BCLDP. RCRA compliance is the responsibility of Battelle's Hazardous Waste Operations Group. DOE has liability only for radioactive issues; and thus only for those hazardous wastes which have collateral radioactivity. Battelle's permitted storage facilities are utilized by BCLDP as necessary to maintain costeffective packaging and shipping operations. Hazardous waste operations for Battelle are currently conducted under an Ohio Hazardous Waste Facility Installation and Operation Permit.

The Ohio EPA did not issue, as planned in 1994, a renewed RCRA Hazardous Waste Facility Installation and Operation Permit allowing continued waste operations until the waste management building is renovated to meet the Part B requirements. Due to operational changes and reengineering of programs, along with concern expressed by members of the public, the Ohio Hazardous Waste Facility Installation and Operation Permit renewal application and the Hazardous Waste Facility Installation and Operation Permit were withdrawn by Battelle on January 13, 1995. The closure plan in the Part B application was modified to include only the interim status storage areas on the current permit. The plan was submitted to the Ohio EPA, and comments sent to Battelle on March 29, 1995. The revised closure plan, incorporating Ohio EPA's comments, has been submitted.

The RCRA Hazardous and Solid Waste Amendments of 1984 (HSWA) permit (a.k.a. corrective action permit) was verbally withdrawn by the US EPA.

\section{Federal Facility Compliance Act (FFCA)}

The draft BCLDP Site Treatment Plan was submitted to the Ohio EPA in August 1994. The plan presented current estimates of the types and amounts of mixed waste that may result throughout the BCLDP project. In addition, the plan discussed several options to the current mixed waste treatment method, including sending specific mixed wastes to an off-site treatment facility or combining BCLDP mixed wastes with similar waste streams at larger DOE facilities in Ohio.

\section{National Environmental Policy Act (NEPA)}

Activities performed for the BCLDP during 1994 were consistent with the existing Environmental Assessment and Finding of No Significant Impact (FONSI) issued by the EPA in 1990.

\section{Clean Air Act (CAA)}

Requirements under the CAA, including the National Emissions Standards for Hazardous Air Pollutants (NESHAPS), were met and no citations were issued. Battelle submitted a letter of correspondence on March 28, 1995 to the US EPA Region 5 stating that compliance with the dose standard provisions were demonstrated by use of the COMPLY air dispersion model. Calculated emissions were significantly less than 10 percent of the dose standard for both radioactive materials and radioiodines and therefore, Battelle was both compliant with Subpart I and was exempt from the reporting requirements of $40 \mathrm{CFR}$ 61.104(a).

Battelle responded to the Ohio EPA on questions concerning a verified complaint filed by a member of a concerned citizens' group. This complaint alleged violations of NESHAPS for radionuclides. After reviewing the Battelle data, the Ohio EPA dismissed the complaint stating that no violations were observed.

\section{Clean Water Act (CWA)}

The CWA is administered in Ohio by the Ohio EPA. Battelle was issued a Notice of Violation (NOV) on the north/middle areas discharge point from a selfreported violation due to a minor exceedance of the total suspended solids limit in September. There was no impact on the environment from the exceedance and there were no enforcement repercussions.

\section{Safe Drinking Water Act (SDWA)}

The SDWA is administered in Ohio by the Ohio EPA. No violations have occurred and no enforcement actions were taken under this act in connection with the BCLDP.

\section{Toxic Substances Control Act (TSCA)}

No violations have been cited by the Ohio EPA and no enforcement actions were taken under TSCA in connection with the BCLDP. PCB wastes were properly handled and the Ohio EPA was notified that 
65 gallons of low-level radioactive PCB waste remain onsite due to lack of treatment and disposal facilities options.

\section{Superfund Amendments and Reauthorization Act (SARA) Title III}

The SARA Title III is not applicable to the BCLDP; however, Battelle voluntarily participates in the group locally responsible for implementing SARA Title III.

\section{Federal Insecticide, Fungicide, and Rodenticide Act (FIFRA)}

The FIFRA is not applicable. Pesticides are not used in BCLDP activities.

\section{Endangered Species Act (ESA)}

No endangered species have been identified in the areas around Battelle's King Avenue facility. At the West Jefferson Site, the following species have been identified:

\section{Federal and Ohio Lists}

- Clubshell (Pleurobema clava)

- Northern riffleshell (Epioblasma torulosa rangiana)

\section{Ohio List}

- Rabbitsfoot (Quadrula cyclindrica cylindrica)

\section{Ohio Special Interest Species}

- Wavy-rayed lampmussel (Lampsilis fasciola)

- Round pig-toe (Pleurobema sintoxia)

\section{Federal Wild and Scenic Rivers Act}

The Big Darby Creek was designated as a component of the National Wild and Scenic River System on March 10, 1994. At the present time, the BCLDP activities are not subject to the requirements under this act because they do not affect the free-flowing nature of the Big Darby Creek. There may be additional state or local requirements imposed in the future.

\section{National Historic Preservation Act (NHPA)}

Several lots located on the east and southeast portions of the Battelle King Avenue site, as well as one small apartment building located on the south- central portion of the site, are considered to be within the boundaries of the Near Northside Historic District. These areas are subject to provisions in 36 CFR 636 and 36 CFR 800. BCLDP activities did not take place within the historic district.

\section{Executive Order 11988 "Floodplain Management"}

Portions of the West Jefferson site are located in the 100-year floodplain for the Big Darby Creek, however, the $\mathrm{JN}-1, \mathrm{~N}-2$, and $\mathrm{JN}-3$ buildings are not located in the floodplain. Several buildings on the King Avenue site are located in the 100-year floodplain of the Olentangy River. The Battelle facilities are separated from the river by a levee, the crest of which is above the 100-year flood level. Battelle has submitted a Conditional Letter of Map Revision (CLOMR) application to the Federal Emergency Management Agency (FEMA) outlining Battelle's proposed actions to enable FEMA to certify the adequacy of the levee and thereby to reclassify the location of the facilities as not being in the floodplain. Battelle has received the approved CLOMR and plans to complete the actions proposed in the CLOMR by mid-1995 and address any concerns that the City of Columbus and the Ohio Department of Natural Resources may have. A Letter of Map Revision (LOMR) application will be submitted by Battelle and receipt of the approved LOMR by the end of 1995. Since BCLDP activities during 1994 incurred no adverse impacts associated with the occupancy, modification, or development of these floodplains, this order has no applicability to the project.

\section{Executive Order 11990 "Protection of Wetlands"}

This Executive Order 11990 is not applicable. Wetlands have not been identified at the BCLDP sites.

\section{Environmental Permits}

A permit application and discretionary exemption for an emergency generator for the West Jefferson site Decontamination and Decommissioning (D\&D) operations was submitted to the Ohio EPA on June 17, 1994. A Permit to Install for an emergency generator at the West Jefferson north area ( $\mathrm{N}-6$ ) was issued in 1994.

\section{List of Environmental Permits}

The following is a list of active environmental permits for Battelle Columbus Operations that are associated with the BCLDP. 


\section{Columbus Laboratory}

a. Air (PTO: Permit to Operate)

1. Building 3 - Beryllium lab hood, PTO \#0125040520/P001 was withdrawn by Battelle in 1994 since the source has been decommissioned and no longer exists.

2. Building 5 - Beryllium machine shop, PTO \#0125040520/P002 was withdrawn by Battelle in 1994 because the shop is no longer operational and a permit is no longer required.

b. Water

NPDES permit \#4IN00012*DD for King Avenue is not associated with BCLDP operations. NPDES Storm Water General Permit For Industrial Activity \#OHR000113 is required for the hazardous waste storage pad.

\section{c. Hazardous Waste}

1. Ohio Hazardous Waste Facility Installation and Operation Permit \#01-25-0572 was withdrawn by Battelle on January 13, 1995. It is still in effect until closure is completed and approved by the Ohio EPA. This is expected by late 1995 .

2. US EPA interim status - Part $A$ and PCB notification OHD007901598.

The Part A notification was withdrawn on January 13, 1995 along with the Ohio waste permit. Battelle maintains interim status until closure is completed and approved by the Ohio EPA. This is expected by late 1995 . The PCB notification will remain in effect.

3. Public Utilities Commission of Ohio (PUCO) Hazardous Waste Transporter Registration - 310-HW, Annual Stamp No. 005531. PUCO has replaced this registration with a Uniform Program Registration for State Hazardous Materials Transportation Programs which includes US DOT and Ohio PUCO registration for transportation of hazardous materials and hazardous wastes. Due to the onerous permit requirements, the hazardous waste portion of the permit was not renewed and subsequently expired on January 31, 1995.
4. Public Utilities Commission of Ohio (PUCO) Hazardous Materials Carrier Registration, Ohio Motor Carrier (OMC\#) 018903. The hazardous materials portion was renewed on September 30, 1994. Due to the large number of permits requested, $P U C O$ has sent a Notice of Filing letter authorizing Battelle to operate under the registration which expired on December 31, 1994.

5. U.S. DOT Hazardous Materials Certificate of Registration, No. 062194 $679008 \mathrm{C}$. This registration has been renewed and is valid until June 30, 1995. Ohio, in a pilot uniform program, is registering hazardous materials transportation for the US DOT. PUCO plans to send out the new registrations before the June 30th expiration date.

6. Tennessee Delivery License No. T-OH004-L95.

\section{West Jefferson Laboratory}

a. $\underline{\text { Air }}$

1. Building JN-1 Boilers $-0149000074 /$ $\mathrm{B} 001$, is on registration status with Ohio EPA.

2. Building JN-2 Boiler-0149000077/ $\mathrm{B} 002$, is on registration status with Ohio EPA.

3. Building JN-3 Boiler-0149000074/ $\mathrm{B} 003$, is on registration status with Ohio EPA.

4. $\mathrm{N}-1$ underground storage tank-PTI $0149000077 / \mathrm{T} 001$, is on registration status with Ohio EPA.

5. Building $\mathrm{JN}-6$ Emergency generator 0149000077/B012, Permit to Install was issued in 1994

b. Water

1. NPDES Permit 4IN00004*DD

2. Ohio EPA License to Operate or Maintain a Public Water System, PWSID: 4930212

\section{c. Hazardous Waste}

1. Hazardous waste generator identification number - OHT400013892

2. Tennessee Delivery License No. T-OH007-L95 


\section{Environmental Program Information}

$\mathbf{T}$ The Battelle Columbus Laboratories Decommissioning Project (BCLDP) has an environmental program that consists of an environmental monitoring program, environmental compliance awareness and evaluation activities, and programs for waste minimization and pollution prevention.

There is a Waste Minimization and Pollution Prevention Plan for the BCLDP. The plan addresses only the minimization of radioactive waste, because the program involves only D\&D of existing contaminated (or radioactive) facilities. No other operations or activities generate significant quantities of waste (other than paper, which is recycled) that could be effectively minimized. The BCLDP Waste Management Manager is responsible for the annual review and updating of the Waste Minimization and Pollution Prevention Plan. Waste minimization is also included in the Waste Quality Assurance (QA) Plan, Low-Level Waste (LLW) Certification Plan, Transuranic (TRU) Waste Certification Plan, and D\&D Work Plans.

A program for training employees in pollution prevention awareness is in place. The BCLDP Program Manager has issued a copy of DOE's Environmental Policy Statement, and specific instructions for compliance, to all persons involved in BCLDP operations. Pollution prevention training and awareness are addressed in the Waste Minimization and Pollution Prevention Plan, and pollution prevention is also included in the support/commitment and policy statements of this plan.

The BCLDP Emergency Management Plan and associated procedures support an effective emergency preparedness program that: (1) has clearly defined command and control authorities, and (2) is compatible with other Battelle Columbus emergency management programs. The Safety, Health and Environmental Support (SH\&ES) Manager for the BCLDP is delegated the responsibility and the authority from the Office of the Battelle Chief Executive Officer (CEO), through the Program Manager for the BCLDP, to maintain the emergency response capability for all BCLDP areas.

Emergency Operations Centers (EOCs) equipped with telephones, area maps, status boards, and other

supplies are located at both the King Avenue and West Jefferson sites. Communications capabilities and notification pathways are well organized internally to facilitate notification of off-site responders and authorities, as well as Battelle senior management. Battelle is committed to using its expertise to support and protect off-site responders and the environment from site hazards during an emergency.

General training on emergency procedures is provided to employees including management, subcontractor personnel, and off-site responders. Training includes briefings, mini-drills, table-top exercises, coached drills, and full-scale exercises. As part of the emergency preparedness program, the BCLDP sponsored an integrated emergency exercise at its West Jefferson facility on September 28, 1994. Personnel who participated in this emergency drill included The Ohio State University Medical Center, Jefferson Township Fire Department, and local law enforcement agencies.

The impact of operations on the health and safety of the public is evaluated routinely by an environmental monitoring program that has been in effect since 1955 . The basic objective of the environmental monitoring program is to evaluate the effectiveness of the waste management program including control of effluent releases at both sites. Concentrations of radioactive and nonradioactive wastes are controlled so that effluent levels are maintained as low as reasonably achievable and well within applicable standards. Effluents involving potentially polluting materials are contained within the operating facilities to the extent possible and are disposed of as packaged wastes by authorized services.

Environmental monitoring under the BCLDP is limited by the nature of the $S \& M$ and $D \& D$ activities. With few exceptions, only radiological monitoring is being performed routinely under S\&M. D\&D operations include radiological pre-characterization and characterization of facilities, equipment removal, decontamination of facilities, and disposal of waste. Nonradiological monitoring performed in connection with the BCLDP is presented in a separate section following the section pertaining to radiological monitoring. 
The BCLDP continued to implement a formal environmental oversight program during 1994. The oversight group consists of ES\&H staff at Battelle whose mission is to independently verify that the BCLDP programs for environmental compliance and environmental monitoring meet Federal, State, and local environmental requirements. The oversight group assists with compliance by providing technical support to evaluate the applicability of requirements and conduct independent assessments and surveillances of on-going activities.

\section{Environmental Radiological Monitoring}

\section{West Jefferson Site}

\section{A inventory of suspected radionuclide A effluents for air and water media is presented $\angle$ in Table 3, Annual Radionuclide} Inventory-West Jefferson Site. The inventory presented in Table 3 for air emissions is comprised of data compiled from each of the emission discharge points cited in the Effluent Information System/Onsite Discharge Information System (EIS/ODIS) reports submitted to the DOE, annually. The values for the inventoried isotopes for both air and water media were based on the MDL values calculated for each of the listed isotopes. Weekly samples were screened for possible elevated levels of radioactivity by counting for gross alpha and gross beta-gamma. Weekly samples were then composited into monthly and quarterly samples for isotopic analysis. For radionuclide concentrations that were too low to be measurable, the MDLs were assumed to be positive releases for purposes of calculating dose assessments. This assumption is a conservative measure performed in order to establish a release inventory and estimate maximum possible doses to the public.

\section{Air}

During CY 1994, upgraded isokinetic air sampling trains were designed by Battelle and installed into existing JN-1 stack ducts. Selection of the sampling ports and placement of the sample nozzle orifices of the sample trains were performed in accordance with technical guidance cited in ANSI13.1-1969 "Guide to Sampling Airborne Radioactive Materials in Nuclear Facilities". Testing and installation of the isokinetic sample trains was compliant with the BCLDP Quality Procedure "Design Control". Radionuclide emissions are collected and measured based upon the principals cited in 40 CFR 61, Appendix B, Method 114.

Stack air samplers continuously monitor the exhaust stack emissions from the major source contributors (i.e., JN-1, JN-2) to assess the effectiveness of the systems controlling airborne emissions. Radiological stack monitors ensure detection of an inadvertent release of radioactive materials and provide data for the prompt assessment of possible environmental impact (see Figure 5 for location). Representative particulate samples of the air effluent were collected from each exhaust stack on Type AE glass fiber filter paper. The air was sampled at an average volume of $1.5 \mathrm{cubic}$ feet/minute $(\mathrm{cfm})$. This volume was selected to facilitate statistical calculations for activity concentrations which are well below regulatory standards.

Table 4, Annual Average Radionuclide Concentrations from Stack Emissions-West Jefferson Site 1994 provides a summary of the average annual radionuclide concentrations and the corresponding release rates for stacks 001 through $004,012,013$ and 014 (see Figure 5). Radionuclide sources were removed from the JN-2 vault early in CY 1994. Therefore, stack emissions emanating from the $\mathrm{N} N-2$ SNM vault, stack 006, are not included in this report. Calculations were performed using CAP88PC air dispersion modeling in order to determine the annual average radionuclide concen-tration that would potentially exist at the West Jefferson site boundaries. These modeling results ascertained that the annual average concentration at the site boundaries was many orders of magnitude below those concentration guidelines specified in 10 CFR 20.1001-20.2401, Table 2 of Appendix B, as well as the Derived Concentration Guide (DCG) values specified in DOE Order 5400.5. The radionuclide concentrations values calculated for the north sector of the West Jefferson site are cited in Table 4 These radionuclide concentrations represent maximum values calculated using CAP88PC air dispersion modeling. Radionuclide concentrations calculated for other geographical sectors were substantially less than those 
values calculated for the north sector, as indicated in Table 4.

Stack air effluent samples were collected weekly and screened for gross alpha and gross beta-gamma radioactivity. These sample data were utilized to: (1) trend routine emissions from BCLDP activities and (2) ensure that preventative measures are implemented in order to detect a possible inadvertent release of radioactive materials to the environment. Subsequent monthly composites of these stack air effluent samples were compiled and analyzed for specific gamma emitting radionuclides. Additional radiochemical analyse were performed on a quarterly basis for alpha and beta emitting radionuclides. Gamma spectrometric analyses are performed using an intrinsic germanium detector coupled to a Nuclear Data Model ND66 multichannel analyzer.

Supplemental continuous air sampling was performed at four site perimeter locations during 1994 (Figure 6). These air sample filters were analyzed on a weekly basis for gross alpha and gross beta-gamma activities. Quarterly composite air samples from these four site boundary locations were analyzed for $\mathrm{Pu}-238, \mathrm{Pu}-239$, Sr-90, natural-U, and gamma-emitting radionuclides (Table 5, Summary of Site Boundary Air Sample Analyses, West Jefferson Site-1994). Collectively, these air sampling data are used to ascertain, by field measurements, that radionuclide emissions emanating as a result of BCLDP activities are compliant with Federal, State and Local regulatory statutes and pose no significant impact to human health or the environment.

\section{Water}

A sanitary sewage system, which is operated in accordance with State of Ohio regulations under NPDES Permit 4 IN00004*DD, handles the sanitary sewerage generated on the West Jefferson north site. The liquids are first treated in a 2,500-gallon septic tank and then released to a 2,160-sq. ft. contained sand and gravel filter bed (Figure 5). From the filter bed the effluent goes to a chlorinating system prior to release to Big Darby Creek.

A continuous water sampling system was used to sample sanitary liquid effluents from the Nuclear Sciences Area to Big Darby Creek after discharge from the chlorinating system. The effluent samples were analyzed weekly for gross alpha and beta activity in suspended and dissolved fractions. Any sample exceeding $3 \times 10^{-8} \mu \mathrm{Ci} / \mathrm{ml}$ received a supplementary gamma isotopic analysis and/or an alpha spectrometric analysis as appropriate. The weekly samples were held, composited, and subjected to gamma spectrometric analyses. Specific analyses for $\mathrm{Pu}-238$, $\mathrm{Pu}-239, \mathrm{Sr}-90$, and natural-U were performed on quarterly composites. The concentrations of gross alpha and gross beta activity in suspended and dissolved fractions as well as the concentrations of specific radionuclides identified in the sample are summarized in Table 6, Summary of Liquid Radioactive Emissions, West Jefferson Site-1994. In most cases, the activity in the samples was due to a mixture of nuclides.

The noncommunity drinking water supply at the West Jefferson site is exempt from radiological monitoring per Ohio EPA review. ${ }^{(6)}$ However, weekly drinking water samples were collected from a tap at the Nuclear Sciences Area to verify compliance with applicable water quality standards for radioactivity in drinking water. The weekly drinking water samples were composited and analyzed monthly for gross alpha and beta activity in suspended and dissolved fractions. Any sample exceeding $1.5 \times 10^{-5} \mu \mathrm{Ci} / \mathrm{ml}$ for gross alpha activity received a supplementary gamma isotopic analysis and/or an alpha spectrometric analysis as appropriate. In 1994, the average concentrations of gross alpha were $(4.08 \pm 5.30) \mathrm{x}$ $10^{-6} \mu \mathrm{Ci} / \mathrm{ml}$ (soluble) and $(0.27 \pm 0.66) \times 10^{-6} \mu \mathrm{Ci} / \mathrm{ml}$ (insoluble) for a total concentration of gross alpha of $(4.35 \pm 5.34) \times 10^{-6} \mu \mathrm{Ci} / \mathrm{ml}$. The average concentrations of gross beta were $(2.86 \pm 1.60) \times 10^{-6} \mu \mathrm{Ci} / \mathrm{ml}$ (soluble) and $(0.13 \pm 0.80) \times 10^{-6} \mu \mathrm{Ci} / \mathrm{ml}$ (insoluble) for a total concentration of gross beta of $(2.99 \pm 1.78)$ $x 10^{-6} \mu \mathrm{Ci} / \mathrm{ml}$. The values are listed in Table 7, Summary of Alpha/Beta Radiological Analyses of Drinking Water Samples, West Jefferson/King Avenue Sites-1994. The average total gross alpha activity represents about 29 percent of the EPA standard of $1.5 \times 10^{-5} \mu \mathrm{Ci} / \mathrm{ml}$ for gross alpha particulate activity in drinking water.

Supplementary water samples were collected weekly at sampling points located $18.3 \mathrm{~m}$ above and $18.3 \mathrm{~m}$ below the sanitary drain outfall at Big Darby Creek. Water samples were also collected weekly below the Battelle Lake dam and at the drain spillway at Big Darby Creek (Figure 6). The supplementary water samples were analyzed monthly for mixed alpha and beta activity. The average concentrations of total activity in the downstream water samples and below the dam water samples were less than $4.43 \times 10^{-9} \mu \mathrm{Ci}$ / 
$\mathrm{ml}$ for alpha and less than $6.39 \times 10^{-9} \mu \mathrm{Ci} / \mathrm{ml}$ for beta activity and showed no significant difference from the upstream control sample (Table 8, Summary of Radiological Analyses of Environmental Water Samples, West Jefferson Site-1994). These findings show that liquid effluent releases from the site to Big Darby Creek did not exceed background levels of radioactivity already present in Big Darby Creek.

\section{Grass and Field Crops}

Grass and field crop samples were collected from the surrounding area. The intent of this portion of the Environmental Monitoring Program is to determine whether there is uptake and concentration of radionuclides by plant or animal life. Where possible, sampling sites are chosen at maximum deposition locations predicted by meteorological studies. Grass and field crop (soybean or field corn) samples are collected at varying distances and directions within a 6-mile (9.6-km) radius of the Nuclear Sciences Area as shown in Figure 7. Sampling locations falling within the same sector are composited. The samples are analyzed for Pu-238, Pu-239, Sr-90, and natural-U. A qualitative analysis by gamma scan is also performed. The results of the grass and field crop analyses are summarized in Table 9, Summary of Radiological Analyses of Grass-West Jefferson-1994 and Table 10, Summary of Radiological Analyses of Field Crops, West Jefferson Site-1994. In both the grass and field crops, the levels of Pu-238, Pu-239, and Sr-90 were at or below the minimum detectable level or not statistically significant for each isotope.

\section{Garden Crops}

Two samples are collected annually to assess the possible impact on garden crops grown at the West Jefferson site. A composite sample of various vegetables from the Battelle employee garden area was compared to a composite of garden vegetables taken from an off-site location. Figure 7 shows the locations of the on-site and off-site garden plots. A gamma isotopic and $\mathrm{Pu}-238, \mathrm{Pu}-239, \mathrm{Sr}-90$, and natural-U analyses were performed. The results of the analyses are shown in Table 11, Summary of Radiological Analyses of Garden Crops, West Jefferson Site-1994. A comparison of sample locations shows that there were no statistically significant radionuclides detected in either sample location. Therefore, there is no impact to the on-site garden.

\section{Sediment}

Sediment samples were collected in June and October at five locations, at approximately $18.3 \mathrm{~m}$ above and $18.3 \mathrm{~m}$ below the point of sanitary effluent release to Big Darby Creek, at the storm sewer outfall leading to Battelle Lake, at the liquid effluent discharge point into Big Darby Creek, and at the dam spillway to Big Darby Creek (see Figure 6). The purpose of collecting sediment samples semi-annually is to estimate the inventory of certain radionuclides deposited in the Big Darby Creek and document it for future reference. The sediment samples were analyzed for $\mathrm{Pu}-238$, $\mathrm{Pu}-239, \mathrm{Sr}-90$, and natural-U. A quantitative gamma isotopic analysis was also performed and showed positive results of $2.86 \mathrm{pCi} / \mathrm{g}$ of U-238, $6.37 \mathrm{pCi} / \mathrm{g}$ of $\mathrm{Cs}-137$, and $8.55 \mathrm{pCi} / \mathrm{g}$ of Sr-90 at the storm sewer outfall (ED-1, near $\mathrm{N}-1$ on Figure 6). This area is contained on site, behind a security fence which precludes public exposure and is not considered to be a risk to the public. The area has been under study for remediation. Samples taken from other points indicate the levels are at or below upstream levels. The complete results of the sediment analyses are summarized in Table 12, Summary of Radiological Analyses of Sediment Samples, West Jefferson Site-1994.

\section{Soil}

Annual soil samples were collected from 20 locations at varying distances and directions within a 6-mile $(9.6-\mathrm{km})$ radius of the Nuclear Sciences Area. Locations (Figure 7) falling within the same sector are composited. The soil samples were collected to a depth of $10 \mathrm{~cm}$ using a 10-cm soil plugging tool. Each soil sample consisted of a composite of five "plugs" of soil collected at random from an area of approximately $1 \mathrm{~m}^{2}$. Prior to analysis, the composite samples were air dried and then blended in a pulverizing mill. The soil samples were analyzed for Pu-238, Pu-239, Sr-90, and natural-U. A qualitative analysis by a gamma spectrometry scan was also performed. The results of the analyses are summarized in Table 13, Summary of Soil Analyses-West Jefferson Site-1994.

Results for $\mathrm{Sr}-90, \mathrm{Pu}-238$, and $\mathrm{Pu}-239$ were at or below the minimum detectable level or not statistically significant from background for these isotopes. Gamma isotopic analyses of the soil samples showed detectable concentration of Cs-137 in ten of the twelve sectors. The Cs-137 is believed to be attributable to 
the settling out of the atmospheric releases from offsite, and not on-site activities. The natural- $U$ detected in all twelve sectors is attributed to the natural component in soil.

\section{Fish}

Fish were collected semi-annually from Battelle Lake and as available from Big Darby Creek, to determine if any radioactive material is entering the food chain. Fish collection in Big Darby Creek was limited to within a hundred yards of the liquid effluent outfall and the Battelle Lake spillway. The fish tissue was analyzed for gamma emitting isotopes, $\mathrm{Pu}-238, \mathrm{Pu}-$ $239, \mathrm{Sr}-90$, and natural-U. Fish were collected from Battelle Lake during June and November 1994 and from Big Darby Creek during September 1994. The results of the analyses were at or below minimum detectable levels for each isotope. Table 14, Summary of Fish Tissue Analyses-West Jefferson Site-1994, summarizes the 1994 data from the analyses.

\section{Background Radiation Levels}

The radiation exposure limit established for the general public by the Department of Energy is $100 \mathrm{mrem} / \mathrm{yr} .^{(7)}$ This value does not include the contribution from natural background radiation, which, in previous years, averaged approximately $130 \mathrm{mrem} /$ yr off site from all sources except radon. Figure 8 shows the location of the 16 dosimetry stations that continuously monitor the external radiation background levels at the West Jefferson site. The dosimetry stations are equipped with commercially available environmental TLD packets that are changed and evaluated each calendar quarter. Based on data provided by the 16 dosimeter stations, the 1994 annual average dose including background at the site boundary is $120 \pm 10 \mathrm{mrem}$. Therefore, there is no measurable contribution from the West Jefferson facilities to off-site public, external radiation doses. The results are summarized in Table 15, Integrated External Background Radiation Measurements at Recreation Area and Property Boundary Line, West Jefferson Site-1994.

\section{Fence Post Dose Estimate}

The "fence post" dose is the maximum measured cumulative dose of radiation possible to an individual having access to an uncontrolled area. It does not include ingestion and inhalation pathways. The "fence post" dose for 1994 was equal to the annual average
TLD background reading of 120 mrem measured at off-site background monitoring stations.

\section{King Avenue Site}

Relatively few radionuclide samples were collected from the Central Staging Area emission sources reported in the 1993 SER because these vents were dismantled early in CY 1994. Consequently, no quarterly radioanalytic data was available for submission in this report for these emission sources.

A comprehensive radionuclide inventory representing the quantity of radioactive materials available for release is maintained by the BCLDP Radiological Technical Support staff for the King Avenue site. These data are compiled annually in order to calculate an Effective Dose Equivalent (EDE), to perform a dose assessment for the public. The EDE is calculated using the COMPLY air dispersion modeling computer program. This air dispersion modeling methodology is used to demonstrate compliance with the dose standard cited in 40 CFR 61 Subpart I. The air dispersion modeling program calculates a dose assessment based on the quantity of radioactive materials that are available for release for the reporting period. Using this model, an EDE of $8.2 \times 10^{-3}$ mrem/year of radionuclide emissions from D\&D activities at the King Avenue site was calculated for members of the general public. These data indicate that the BCLDP remains compliant with the dose standard cited in Section 61.102, and is exempt from the reporting requirements cited in Section 61.104.

\section{Air}

The BCLDP maintains Environmental Air (EA) samplers which continuously monitor air effluents at the King Avenue site boundary. (see Figure 4). Analyses of these air samples are used to assess, by field measurement, the potential environmental impact posed to the neighboring community. The values obtained by field measurements substantiate the dose assessment calculated by the COMPLY air dispersion modeling program in order to assess the potential risks associated with radionuclide emissions emanating from BCLDP operations.

Early in CY 1994, the BCLDP installed three environmental air (EA) samplers, EA-16, EA-17 and EA-18, along with the EA-15 reported in the 1993 SER, which continuously monitor possible 
radionuclide emissions at locations surrounding the King Avenue site during CY 1994. Air samples collected from these continuous EA samplers were screened weekly for gross alpha and gross beta-gamma radioactivity. Analyses from these weekly air samples were reviewed in order to trend radionuclide emissions and assess any potential impact posed to the environment. Quarterly composites of these EA samples were analyzed for specific gamma emitting radionuclides. Additional radiochemical analysis were also performed for alpha and beta emitting isotopes on a quarterly basis. Radioanalytic results obtained for each of the sampling locations were below the minimal detectable limits (MDL) of the specific counting instrumentation. Table 16, Summary of Site Boundary Air Sample Analyses, King Avenue Site-1994, provides a summary of the radioanalytical data pertaining to the King Avenue site perimeter air sampling program. These data, substantiated by the results obtained from the COMPLY air dispersion modeling computer program, illustrate the nonsignificant impact from radionuclide emissions posed to the neighboring community as a result of activities conducted by the BCLDP.

\section{Water}

Wastewater discharges to the Columbus Municipal Waste Water Treatment Plant via the sewer system, were monitored at six locations. See Figure 4 for the locations. Sampling of liquid discharges from the Building 2 and Building 3 sumps to the municipal sewer system was performed on a weekly basis. This discharge consisted of the liquid wastes from the building laboratory drain systems. Monthly composites were then prepared from these weekly collections and received gross alpha and gross beta, and gamma isotopic analysis. In addition, Th-isotopic and natural-U analyses were performed on quarterly composites. Beginning in July, the Building 3 sump was closed during remediation and no longer sampled. These results are summarized in Table 17, Radiological Analyses of Liquid Discharges-King Avenue Site-1994. The aver-age concentrations at all discharge points were well below NRC standards as well as the DOE's DCG for the most restrictive beta activity in the uranium decay chain.

Soil

Nine soil samples were collected at various points around the King Avenue site (Figure 4). Sample KAES-09 was collected from The Ohio State
University Agriculture campus north of the Battelle site as a background reference. The same technique was used as that for soil collected for the West Jefferson off-site soil samples. The data from these collections are presented in Table 18, Radiological Analyses of Soil Samples-King Avenue Site-1994. There was evidence of natural- $U$ in the soil samples above detectable levels in all the on-site samples. There was also comparable levels of natural-U detected in the background sample. U-238 registered above a minimum detectable level in the King Avenue off-site location, but not at the on-site sample locations. There was also evidence of Cs-137 in the King Avenue site soils. It was also detected in the background sample at similar levels. The cesium is in the same range as that seen in West Jefferson off-site samples although no operations involving cesium are conducted at King Avenue. This suggests that the cesium is from fallout and not Battelle operations. Th-228, Th-230, and Th-232 were detected in the samples including the off-site King Avenue location. The presence of these radioisotopes in soil was not attributable to BCLDP operations.

\section{Vegetation}

Nine samples of vegetation were collected at points around the King Avenue site from the same locations as the soil samples, including the off-site background, reference location (Figure 4). Eight of these samples were collected on Battelle's property. The samples received gamma isotopic, thorium, and naturaluranium analysis. Th-228 was detected in the samples except for locations KAEV-04 and KAEV-09; Th-232 was detected in the samples except for locations KAEV-05 and KAEV-09; Th-230 was detected in all samples. The presence of these isotopes in vegetation was not attributed to BCLDP operations due to the regulating practices conducted at Battelle for constituents used in operations performed at Battelle. Natural-uranium was detected in the samples, including the off-site sector. Data from these analyses are presented in Table 19, Radiological Analyses of Vegetation Samples-King Avenue Site-1994.

\section{Sediment}

Sediment samples were collected in September at two locations in the Olentangy River, one near the storm sewer outfall at the low-head dam on the river, just north of Fifth Avenue, (KAED-1) and the other one south of the Ohio State University campus north of King Avenue (KAED-2) (see Figure 4). The purpose 
of collecting the sediment sample is to estimate the inventory of certain radionuclides in this waterway and document it for future reference. A quantitative gamma isotopic and natural uranium were performed. The complete results of the sediment analyses are summarized in Table 20, Radiological Analyses of Sediment Samples, King Avenue Site-1994. Th-228, Th-230, Th-232 and natural-U were detected in samples collected at both locations. In addition, Cs137 was detected slightly above MDA in both sample locations. The presence of these radioisotopes in both the upstream and downstream sediment location is not attributable to BCLDP Operations.

\section{Water}

The drinking water supply at the King Avenue site is exempt from radiological monitoring per Ohio EPA review $^{(6)}$. However, weekly drinking water samples were collected from a tap at the King Avenue Site in Building A to verify compliance with applicable water quality standards for radioactivity in drinking water. The weekly drinking water samples were composited and analyzed monthly for gross alpha and gross beta in suspended and dissolved fractions and gamma isotopic analysis. In 1994, the average concentrations of gross alpha was $(3.97 \pm 2.01) \times 10^{-6} \mu \mathrm{Ci} / \mathrm{ml}$ (soluble) and $(0.58 \pm 0.39) \times 10^{-6} \mu \mathrm{Ci} / \mathrm{ml}$ (insoluble). The total concentrations are $(4.55 \pm 2.05) \times 10^{-6}$ $\mu \mathrm{Ci} / \mathrm{ml}$ for gross alpha and $(5.88 \pm 0.98) \times 10^{-6}$ $\mu \mathrm{Ci} / \mathrm{ml}$ for gross beta. The total concentrations are listed in Table 7. The total gross alpha activity represents about 3 percent of the US EPA standard of $1.5 \times 10^{-5} \mu \mathrm{Ci} / \mathrm{ml}$ for gross alpha particulate activity in drinking water.
One annual river water sample was collected from the Olentangy River at a sampling point located north of the West Fifth Avenue bridge (Figure 4). The water sample was analyzed for mixed alpha and beta activity, gamma isotopic analysis, Th-228, Th-230, Th-232, and natural-U. The average concentration of total activity in the water sample was less than $(7.98 \pm$ $6.78) \times 10^{-9} \mu \mathrm{Ci} / \mathrm{ml}$ for alpha and less than $(7.85 \pm$ 2.20) $\times 10^{-9} \mu \mathrm{Ci} / \mathrm{ml}$ for beta activity (Table 21 , Radiological Analysis of Olentangy River Water Samples, King Avenue Site-1994). Natural-U and Th-232 were detected slightly above MDA in the river water samples.

\section{Fish}

An annual fish sample was collected from the Olentangy River during September at a location just north of the West Fifth Avenue bridge (see Figure 4). The sample included both bottom feeder and non-bottom feeder species. The fish tissue was analyzed for gamma isotopes, Th-228, Th-230, Th-232, and natural-U. The results of the analyses were below minimum detectable levels for both the bottom feeders and non-bottom feeders collected (see Table 22, Summary of Fish Tissue Analyses, King Avenue Site-1994).

\section{Direct Radiation Measurement}

Fifteen thermoluminescence dosimeters (TLDs) were exchanged and evaluated on a quarterly basis around the King Avenue property line for calendar year 1994 (see Figure 9). All readings were less than MDA $(0.030 \mathrm{rem})$ for 1994 . The results are summarized in Table 23, Integrated External Background Radiation Measurements at the Property Line, King Avenue Site-1994.

\section{Environmental Nonradiological Program Information}

1

The drinking water system at the West Jefferson site is monitored under Ohio Environmental Protection Agency (OEPA) regulations, which regulate all public water supplies. As a noncommunity water supply, Battelle was required to perform the following tests in 1994:

- Volatile organic compounds (VOCs) quarterly (exempted by Ohio EPA for 4 previous quarters of nondetection results)
- Total coliform for microbiological contamination-quarterly

- Synthetic organic chemicals (SOCs)quarterly (exempted by Ohio EPA for nondetection results for the first quarter)

- Nitrate-once during last half of the year

- Asbestos-once during last half of the year

- MCL inorganics—once during last half of the year

- Lead and Copper-twice during first and last half of the year. 
For the drinking water system, the only significant changes were:

- Addition of tests for organic chemicals, asbestos, and MCL inorganics

- Deletion of nitrite and VOC tests

- Reduction in the number of samples for lead and copper.

VOC sampling was not done at the north wellhouse due to an exemption received from the Ohio EPA based on four consecutive quarters of nondetection results. All tests for total coliform were negative. The SOC monitoring was done for the first quarter with no SOCs detected. Ohio EPA gave Battelle a susceptibility waiver with SOC monitoring not required for the remainder of CY 1994.

Nitrate was measured and found to be well below the established maximum contamination level (MCL) value of $10 \mathrm{mg} /$. Asbestos was tested and found to be well below the MCL of 7 million fibers/l where only fibers longer than 10 micrometers are counted. Lead and copper results were below the action levels requiring additional monitoring. The Ohio EPA advised Battelle that the number of lead and copper samples can be reduced from ten to five on an annual basis due to the low results.

Liquid effluents discharged from the West Jefferson Facility are subject to the restrictions on an NPDES permit. Battelle monitors and reports on a monthly basis to the Ohio EPA. Table 24, Non-Radiological Water Effluent Analyses, West Jefferson Site-1994, includes a list of parameters for which Battelle is presently required to analyze and report at the North site. The data provided for the North Sanitary Sewer were obtained in accordance with the NPDES Permit 4IN00004*DD issued by the Ohio EPA. All readings were within acceptable limits as specified in the permit for 1994, except for the total suspended solids level in September.

The values listed in Table 24 represent an average of the monthly data collected during the 12-month period starting January 1, 1994, and ending December 31, 1994. The table illustrates the actual performance against permit limits/restrictions. The results in the table are for discharge point 001 which includes the discharge from the West Jefferson North area (Figure 5).

\section{Groundwater Monitoring and Protection Program}

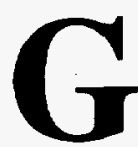

roundwater monitoring at the West Jefferson site included a total of 18 shallow and deep wells. These include three supply wells (JN and JM) at a depth of approximately 130 to 160 feet, three wells designed for chemical monitoring ( $\mathrm{C} 03$, $\mathrm{C} 09$, and C16) at a depth of approximately 30 to 35 feet, and 13 shallow wells at a depth of approximately 10 to 15 feet. The three wells designed for chemical sampling and 13 shallow wells were installed late in 1989. Figures 10 and 11 indicate the location of shallow and chemical monitoring wells. The supply wells are associated with facilities identified in Figures 6 and 10, but are off the scale of the map. Detailed chemical monitoring was performed and reported in Interim Report on Site Characterization, West Jefferson North Site, Stage 1 Sampling and Analysis: Chemical Sampling Summary Report, ${ }^{(10)}$ dated December 22, 1989. No contamination was found in groundwater samples collected at that time.
Detailed chemical analyses were performed on groundwater samples collected December 20, 1994, from the three chemical monitoring wells. Samples from all three wells were analyzed for eight heavy metals, 26 pesticide and PCB compounds, 35 VOCs, 65 semivolatile organic compounds, oil and grease, and $\mathrm{pH}$. The levels for compounds in the samples were below the levels of detection or quantification (Table 25, Nonradiological Analyses of Groundwater, West Jefferson Site-1994).

1,1,1-Trichlorethane detected at a concentration of $7 \mu \mathrm{g} / 1$ from well $\mathrm{Cl} 6$ during 1993 was not detected in 1994. Phenol detected in well $\mathrm{C} 03$ at 17 parts per billion in 1991 was not detected in 1992,1993 , or 1994. No chemical contamination had been found in any of the wells prior to 1991. Possible detection of this chemical will be tracked in subsequent sampling. 
Radiological groundwater monitoring was conducted in June and November. The average annual radiological monitoring results are presented in Table 26, Summary of Alpha/Beta Radiological Analyses of Groundwater, West Jefferson Site-1994, and Table 27, Summary of Radiological Analyses of Groundwater, West Jefferson Site-1994. The highest combined alpha and beta activity is shown to be in well 101, where radioactivity remains in a former remediated filter bed. These data are consistent with previous monitoring data collected since installation of the wells in 1989. This area has been recommended for further remediation in the Final Assessment of the Radiological Status of Battelle's Nuclear Sciences Area, dated January 1991. ${ }^{(11)}$

\section{Evaluation of Dose to the Public}

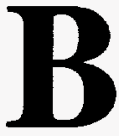
attelle's King Avenue site is not considered in this report to the same extent as is the West Jefferson site because the source term at the King Avenue site is a fraction of the source term at the West Jefferson site and the vast majority of radioactive material associated with the BCLDP at the King Avenue site is fixed contamination. Only nonsignificant amounts of loose contamination that are localized and contained, are present at the King Avenue site.

\section{Estimated Dose to the Public from the King Avenue Site Emissions During 1994}

Compliance with the emission standard cited in 40 CFR 61 Subpart I for the BCLDP operations at the King Avenue site was demonstrated through the use of the EPA computer code COMPLY (level 4). ${ }^{(12)}$ The COMPLY air dispersion modeling program was used to calculate an Effective Dose Equivalent (EDE) of 8.2 $\times 10^{-3} \mathrm{mrem} /$ year for BCLDP activities at the King Avenue site for CY 1994. The results indicate that radionuclide emissions emanating from the BCLDP operations at King Avenue remain compliant with the Section 61.102 dose standard and the BCLDP is exempt from the reporting requirements as cited under Section 61.104 for CY 1994.

A correspondence from Battelle to USEPA Region V submitted on March 28, 1995, addressed issues pertaining to compliance with the dose standard and the reporting requirement exemptions applicable to the BCLDP concerning the National Emissions Standards for Hazardous Air Pollutants (NESHAP) requirements for radionuclide emissions for CY 1994.

Radionuclide emissions that were cited in the 1993 Annual SER regarding the Building KA-3 Central Staging Areas are not presented in this report because these emission sources were dismantled early in $\mathrm{CY}$ 1994. Consequently an insufficient amount of radionuclide air samples were collected from these emission sources to allow for a dose assessment utilizing the CAP88PC air dispersion modeling computer program. $^{(13)}$

\section{Estimated Dose to the Public from the West Jefferson Site Emissions During 1994}

Dose assessments were calculated for radionuclide emissions emanating from the West Jefferson site for BCLDP operations using both the COMPLY (level 4) and the CAP88PC air dispersion models. Each of these models integrates an EDE to members of the general public by considering various environmental pathways and site specific meteorological data. Not only does each of the models demonstrate that radionuclide emissions occurring from BCLDP operations were many orders of magnitude below the US EPA dose standard of $10 \mathrm{mrem} / \mathrm{year}$, but each model predicted a unit of risk based upon either actual measurements from collected environmental field samples, or the quantity of radioactive materials that were utilized by the facility during a calendar year.

BCLDP utilized the COMPLY model because: (1) this model derives an EDE based upon the annual quantity of radioactive materials used by BCLDP without bias associated with the inherent limitation of radioanalytic counting statistics, and (2) it is an acceptable method acceptable used to demonstrate compliance with the dose standard cited in 40 CFR 61 Subpart I. Dose assessments performed using this model for CY 1994, indicate that BCLDP operations conducted at the West Jefferson site are not only compliant with the dose standard cited under Section 61.102, but also exempt 
from the reporting requirements cited under Section 61.104 , cited in the referenced correspondence to the US EPA Region V on March 28, 1995.

In comparison, the CAP88PC air dispersion model was selected to evaluate the potential risk posed to members of the general public because: (1) the calculated EDE derived from this model correlates to the field sample data collected, such as stack effluent samples, (2) site specific data, such as stack height, plume rise and local population distributions are utilized in order to better evaluate a unit of risk, and (3) because additional data such as, annual average radionuclide concentrations at various distances, exposure to critical organs and a collective EDE for person-rem/year can also be calculated.

In summary, both air dispersion models were used to calculate a unit of risk which demonstrated that radionuclide emissions emanating as a result of BCLDP operations remain compliant with applicable regulatory standards and pose no significant impact to human health and the environment.

\section{Atmospheric Discharges}

Calculated releases and ground level annual average concentrations at the site boundary during 1994 from the West Jefferson site are summarized in Tables 3, 4, and 5 . The downwind position from the facility where ground level radionuclide concentrations would be the greatest, is at the north site fence line which determines the perimeter for uncontrolled exposure. Table 4 shows that the total mixed fission and transuranic (TRU) product releases for 1994 totaled $28.83 \mu \mathrm{Ci}$, with an estimated maximum possible EDE to a nearby resident of $2.09 \times 10^{-3} \mathrm{mrem} / \mathrm{yr}$. The isotopic composition of the effluents assumed to be emitted from the seven stacks in $\mathrm{JN}-1$ and one stack of $\mathrm{JN}-2$ was used to evaluate the off-site dose to the public using the CAP88PC air dispersion modeling computer program.

The CAP88PC air dispersion modeling program estimated a $7.64 \times 10^{-3}$ person-rem/year collective population dose for the total population within $80 \mathrm{~km}$ of the West Jefferson site. The doses presented in this report are calculated rather than measured, and they represent an estimate of actual doses.

In comparison, the COMPLY air dispersion modeling computer program calculated an EDE to the public of
$7.40 \times 10^{-4} \mathrm{mrem} / \mathrm{year}$. The calculated EDE discrepancy between CAP88PC and COMPLY air dispersion is attributed to the limitations of the counting statistics used to derive the CAP88PC dose assessment versus the annual quantity of radioactive materials source term utilized by the COMPLY modeling computer program.

\section{Liquid Discharges}

Measured aqueous releases and effluent concentrations during 1994 for the West Jefferson site are summarized in Table 6. The concentration values apply to the water discharged into Big Darby Creek after passage through a treatment system consisting of a settling tank and enclosed surface sand filter. Based on a knowledge of the isotopic composition of radionuclide concentrations released to the surface sand filter, emissions should be due to very limited elution of contaminants from the surface sand filter that were delivered to the bed in the past few years. In order to be conservative, the release inventory values are based on the minimum detectable limits of isotopes listed in Table 6 . The actual release values would be lower.

Due to the shallow nature of Big Darby Creek at the West Jefferson site, there does not appear to be any significant pathway for exposure to boaters, swimmers or water skiers. In addition, water from Big Darby Creek below the outfall is not used for drinking prior to its confluence with the Scioto River according to the U.S. Geological Survey (USGS); therefore, the dose contribution from this source is negligible.

\section{Calculation of Atmospheric Dispersion Parameters}

Meteorological data from the Columbus area were used to compute the dispersion parameters for the West Jefferson and King Avenue sites (see Table 28, Arithmetic Average Wind Speeds and Frequency). The CAP88PC, programmed for localized applications, was used to generate detailed $X / Q$ values. $V$ alues of $X / Q$ represent potential releases of radionuclides (measured in Curies) in relation to wind speed (measured in seconds) at designated distances. Thus, $X / Q$ values were developed for a series of concentric rings extending from the site boundary out to a distance of $80 \mathrm{~km}$ (50 miles). The rings were broken down into sixteen sections corresponding to the 
normal wind rose pattern. The minimum $X / Q$ values for the radionuclides considered are presented in Table 29, Minimum X/Q Dispersion Values at the West Jefferson Site from $J N-1$ and $J N-2$ Stacks.

\section{Computation of Dose Equivalent Rates to Nearby Individuals and Population Groups}

The annual radiation dose from particulate radionuclides assumed to be discharged into the atmosphere was computed for a person continuously immersed in an infinite hemispherical cloud containing the radionuclides. Stack release data (see Table 4) are used to estimate the nearby individual and population group concentrations using actual dispersion conditions, if known. If the conditions are unknown, data representative of a worst case scenario were used. The radionuclide composition and concentration of the atmospheric emissions were used to compute critical organ doses assuming that the more sensitive biological form (soluble or insoluble) of the radionuclide was present. The dose estimates obtained for a nearby individual assume a full-time resident at Camp Ken Jockety, which is adjacent to the West Jefferson site.

The EDE rate for a nearby individual was computed using the CAP88PC air dispersion model. Using this model the EDE at the camp was calculated at $2.09 \mathrm{x}$ $10^{-3} \mathrm{mrem} / \mathrm{year}$, with the highest organ dose being $1.34 \times 10^{-2}$ mrem to the lungs. In comparison, exposure of persons to natural background radiation in the area would be approximately $120 \mathrm{mrem} / \mathrm{year}$ as measured by TLD stations.

For the total population within $80 \mathrm{~km}$ of the West Jefferson site, the estimated collective population dose (EDE) is $7.64 \times 10^{-3}$ person-rem/year.

\section{Quality Assurance}

$O$ everal methods are used to assure that the data collected each year are representative of actual concentrations in the environment. Extensive environmental data are collected to eliminate an unrealistic reliance on only a few results. Newly collected data are compared with historical data for each environmental medium to assure that current values are consistent with previous results. This allows for timely investigation of any unusual results. Samples are collected using identical methods near to and far from the nuclear site, as well as upstream and downstream on Big Darby Creek, to provide for identification of any net differences that may be attributable to the West Jefferson nuclear operations. These procedures, in conjunction with a program to demonstrate the accuracy of radiochemical analyses, assure that the data accurately represent environmental conditions.

With minor exceptions, all of the routine radioanalyses for the Battelle environmental surveillance program are performed at the radiochemistry facility located at the West Jefferson nuclear site. Two outside laboratories (Ecotek, located in Atlanta, Georgia; and Quanterra, located in St. Louis, Missouri) were chosen as a backup service for overflow samples, and performed certain plutonium, thorium, uranium, and strontium analyses. Both laboratories maintain internal quality assurance programs that involve routine calibration of counting instruments, source and background counts, routine yield determinations of radiochemical procedures, and replicate analyses to check precision. The accuracy of radionuclide determination is assured through the use of standards traceable to the National Institute of Standards and Technology (NIST).

Assurance of the dose calculation quality is provided in the following ways. Since doses are similar from year to year, a comparison is made against past calculated doses and any differences are validated. All computed doses are double checked by the originator and by an independent third party, who also checks all input data and assumptions used in calculation. Information necessary to perform all of the calculations is fully documented.

The Battelle Radioanalytical Laboratory (RAL) participates in the semi-annual DOE Environmental Measurements Laboratory (EML) program. This program is designed to monitor a laboratory's performance by submitting samples of known isotopes and quantified activities for analysis. EML submits four types of samples in different matrices for analysis. These matrices consist of water, soil, and vegetation. 
The matrices in 1994 for gamma isotopic analyses were within the EML's activity boundaries.

The RAL reported Sr-90 in water for the second half of the year less than 10 percent from acceptable values. However, a computational error was found and the actual value was within the reported mean from EML. Therefore, all Quality Assurance samples submitted by EML were within acceptable boundaries as reported in Table 30, DOE-EML Quality Assessment Program Results for the Battelle Radioanalytical Laboratory. 


\section{Glossary}

alpha particle. A positively charged particle emitted from the nucleus of an atom having the same charge and mass as that of a helium nucleus ( 2 protons, 2 neutrons).

atom. Smallest particle of an element capable of entering into a chemical reaction.

beta particle. A negatively charged particle emitted from the nucleus of an atom having a mass and charge equal to that of an electron.

contamination. The deposition of unwanted radioactive or hazardous material on the surfaces of structures, areas, or objects.

cosmic radiation. Radiation of many types with very high energies, originating outside the earth's atmosphere. Cosmic radiation is one source contributing to natural background radiation.

curie (Ci). The traditional unit for measurement of radioactivity based on the rate of radioactive disintegration. One curie is defined as $3.7 \times 10^{10}$ (37 billion) disintegrations per second. Several fractions and multiples of the curie are in common usage.

millicurie ( $\mathrm{mCi}$ ). $10^{-3} \mathrm{Ci}$, one-thousandth of a curie; $3.7 \times 10^{7}$ disintegrations per second.

microcurie $(\mu \mathrm{Ci}) \cdot 10^{-6} \mathrm{Ci}$, one-millionth of a curie; $3.7 \times 10^{4}$ disintegrations per second.

picocurie (pCi). $10^{-12} \mathrm{Ci}$, one-trillionth of a curie; $3.7 \times 10^{-2}$ disintegrations per second.

decay, radioactive. The spontaneous transformation of one radionuclide into a different radioactive or nonradioactive nuclide, or into a different energy state of the same radionuclide.

Derived Concentration Guide (DCG). Secondary radioactivity in air and water concentration guides used for comparison to measured radioactivity concentrations. Calculation of DCG assumes that the exposed individual inhales 8,400 cubic meters of air per year or ingests 730 liters of water per year at the specified radioactivity DCG with a resulting radiation dose of 0.1 rem (100 mrem) EDE. dose, absorbed. The amount of energy deposited by radiation in a given mass of material. The unit of absorbed dose is the rad.

dose equivalent. A modification to absorbed dose that expresses the biological effects of all types of radiation (e.g., alpha, beta, gamma) on a common scale. The unit of dose equivalent is the rem or the sievert $(1$ sievert $=100 \mathrm{rem})$.

exposure. A measure of the ionization produced in air by $x$-ray or gamma radiation. The special unit of exposure is the roentgen (R).

gamma-ray. High-energy, short-wavelength electromagnetic radiation emitted from the nucleus of an atom. Gamma radiation frequently accompanies the emission of alpha or beta particles. Gamma rays are identical to x-rays except for the source of the emission.

half-life, radioactive. The time required for a given amount of a radionuclide to lose half of its activity by radioactive decay. Each radionuclide has a unique half-life.

isotopes. Various forms of a chemical element having the same number of protons in their nuclei and differing in the number of neutrons. An element may have many isotopes; some may be radioactive and some may be non-radioactive.

minimum detectable activity/concentration/level (MDA/MDC/MDL). The smallest amount of activity/ concentration of a radioelement that can be distinguished in a sample by a given measurement system in a pre-selected counting time at a given confidence level.

natural radiation. Radiation arising from cosmic sources and from naturally occurring radionuclides (such as radon) present in the human environment.

outfall. The place where a storm sewer or effluent line discharges to the environment.

part per billion (ppb). Concentration unit approximately equivalent to micrograms per liter. 
part per million (ppm). Concentration unit approximately equivalent to milligrams per liter.

person-rem. The traditional unit of collective dose to a population group. For example, a dose of $1 \mathrm{rem}$ to 10 individuals results in a collective dose of 10 person-rem.

rad. A traditional unit of absorbed dose. The International System of Units (SI) unit of absorbed dose is the gray ( 1 gray $=100$ rads).

radioactivity. The spontaneous emission of radiation, generally alpha or beta particles, often accompanied by gamma rays, from the unstable nucleus of an atom.

radionuclide. An atom having an unstable ratio of neutrons to protons so that it will tend toward stability by undergoing radioactivity decay. A radioactive nuclide.

rem. The traditional unit of dose equivalent. Dose equivalent is frequently reported in units of millirem (mrem), which is one-thousandth of a rem. The International System of Units (SI) unit of dose equivalent is the sievert $(1$ sievert $=100 \mathrm{rem})$.

roentgen $(R)$. The traditional unit of exposure to $\mathrm{x}$ ray or gamma radiation based on the ionization in air caused by the radiation. One roentgen is equal to 2.58 x $10^{-4}$ coulombs per kilogram of air. A common expression of radiation exposure is the milliRoentgen $(\mathrm{lR}=1000 \mathrm{mR})$.

source term. The release rate of radioisotopes as it varies with time or the time until release becomes negligible (total source term). This can be an actual "measured" value or based on various assumptions. The units of this value are generally curies per unit time or total.

thermoluminescent dosimeter (TLD). A device used to measure external sources (i.e., outside the body) of penetrating radiation such as $\mathrm{X}$-rays or gamma rays.

uncontrolled area. An area to which access is not controlled for the purpose of protecting individuals from exposure to radiation and radioactive materials.

worldwide fallout. Radioactive debris from atmospheric weapons testing that is either airborne and cycling around the earth or has been deposited on the earth's surface.

$x / q$ value. Ratio of average air concentration to release rate at the source. 


\section{References}

(1) U.S. Bureau of the Census, 1990 Population Data. Prepared by Ohio Department of Development.

(2) Ionizing Radiation Exposure of the Population of the United States, National Council on Radiation Protection and Measurements, NCRP Report No. 93, 1987.

(3) Civil Effects Operations (LEX 59.4.23) Aeroradioactivity Surveys and A Real Geology of Parts of Ohio and Indiana (ARMS-1), May 1966.

(4) "Estimates of Ionizing Radiation Doses in the United States 1960-2000", U.S. Environmental Protection Agency, ORP/CSD 72-1.

(5) Environmental Assessment for Battelle Columbus Laboratories Decommissioning Project, Battelle, Columbus, Ohio, 1990.

(6) Letter to John Paulian from Karen H. Cooper, Ohio EPA-Division of Public Water Supply, dated September 20, 1983.

(7) Radiation Protection to the Public and the Environment, Operational and Environmental Safety Division, DOE Order 5400.5, U.S. Department of Energy, Washington, DC, February 1990.
(8) National Revised Primary Drinking Water Regulations, Chapter I Environmental Protection Agency, 40 CFR Part 141, July 1, 1990.

(9) Scioto River Basin Waste Load Allocation Report for the 303 (e) Continuing Planning Process for Water Quality Management.

(10) Interim Report on Site Characterization West Jefferson North Site Stage 1 Sampling and Analysis-Chemical Sampling Summary Report, Battelle Columbus Operations, M.J. Stenhouse and T. C. Beard, December 22, 1989.

(11) "Final Assessment of the Radiological Status of Battelle's Nuclear Sciences Area," Battelle Columbus Operations, M.J. Stenhouse, January 1991.

(12) User's Guide for the COMPLY Code, Version 2, United States Environmental Protection Agency, Office of Radiation and Indoor Air, Washington, DC, EPA 520/1-89003, October 1989.

(13) User's Guide for CAP88-PC, Version 1.0, United States Environmental Protection Agency, Office of Radiation and Indoor Air, Las Vegas Facility, EPA/402-B-92-001, March 1992. 


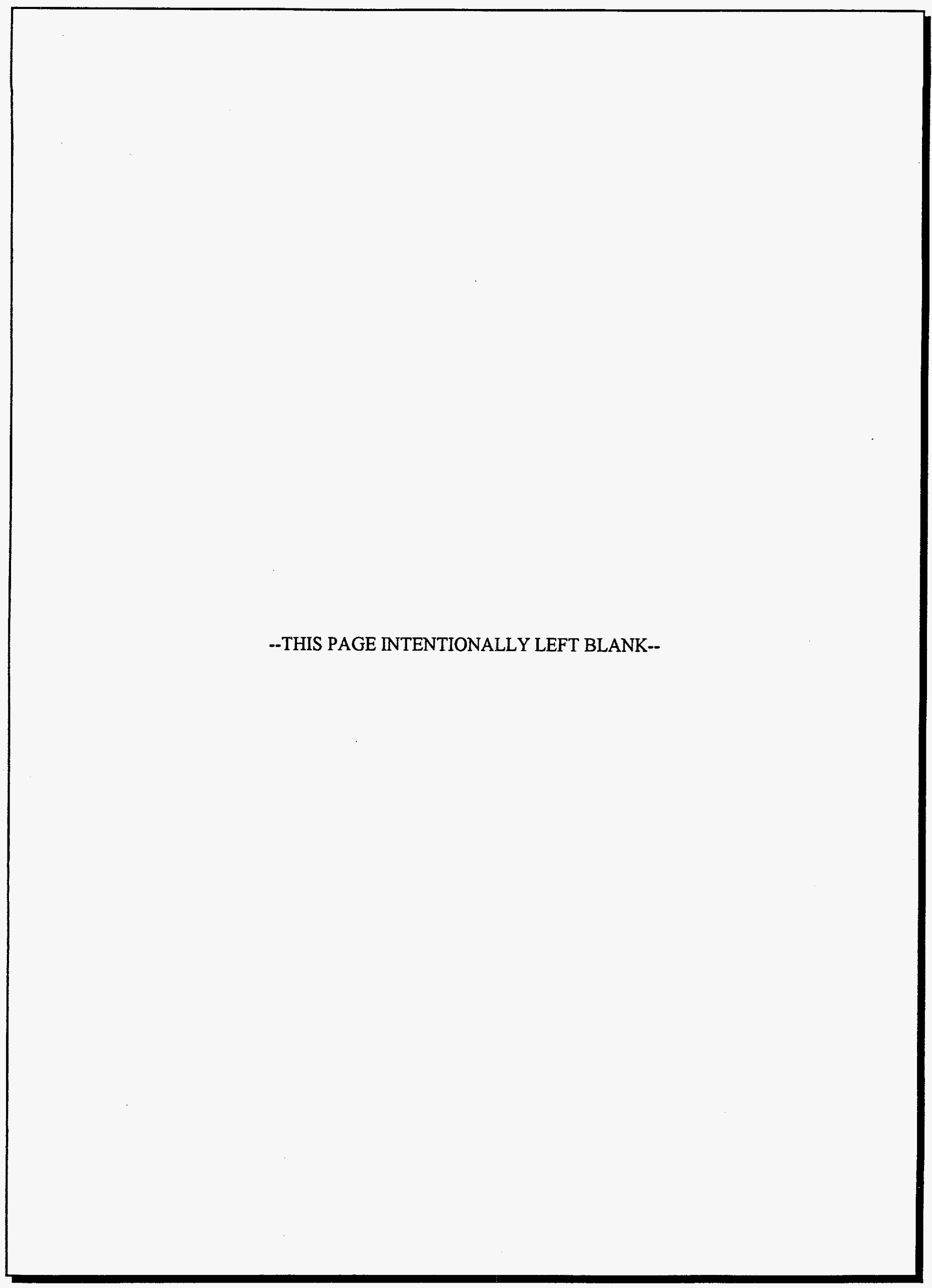


Appendix A

\section{Figures}




\section{--THIS PAGE INTENTIONALLY LEFT BLANK--}




\section{Contents}

\section{Appendix A. List of Figures}

Figure 1. Regional Map for King Avenue and West Jefferson Sites

Figure 2. Local Vicinity Map of King Avenue Site $\ldots \ldots \ldots \ldots \ldots \ldots \ldots \ldots \ldots \ldots$

Figure 3. Local Vicinity Map of Nuclear Sciences Area-West Jefferson Site . . . . . . A-3

Figure 4. Battelle King Avenue Laboratories $\ldots \ldots \ldots \ldots \ldots \ldots \ldots \ldots \ldots \ldots \ldots$

Figure 5. Nuclear Sciences Area-West Jefferson Site $\ldots \ldots \ldots \ldots \ldots \ldots \ldots \ldots$

Figure 6. Map of Site Boundary Air Sampling Locations, and Battelle Lake and Darby Creek Water and Sediment Sampling Locations

Figure 7. Map of Field Crop, Soil and Vegetation

Sampling Locations-West Jefferson Site

Figure 8. Map of TLD Locations Within 3/4-Mile Radius of the

Nuclear Sciences Area

Figure 9.

King Avenue Site TLD Locations

Figure 10. North Site Groundwater Monitoring Wells

Figure 11. Recommended Remedial Action for Remediated

Filter Bed Area (Shaded Area) 
--THIS PAGE INTENTIONALLY LEFT BLANK-- 


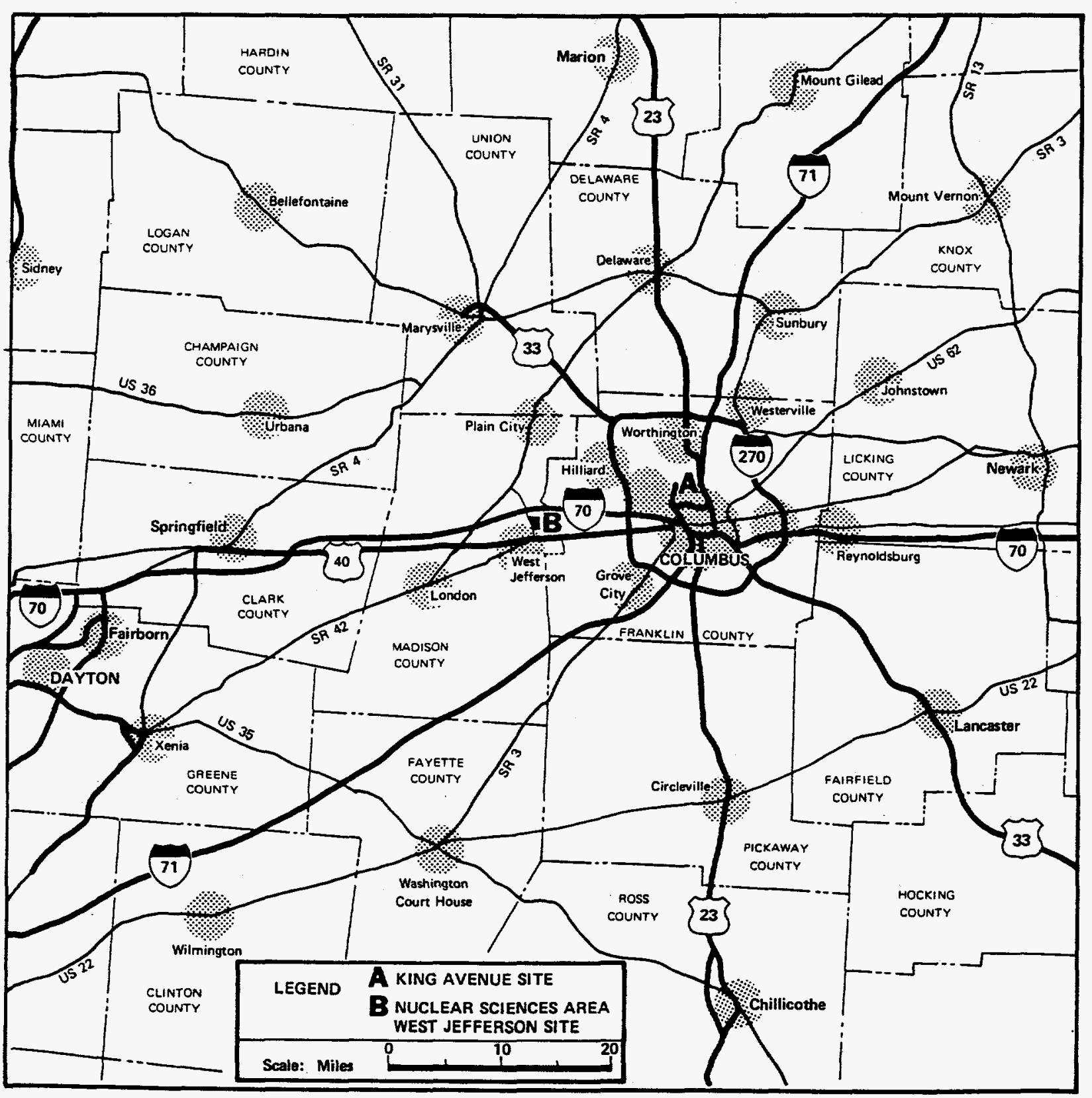

FIGURE 1. REGIONAL MAP FOR KING AVENUE AND WEST JEFFERSON SITES 


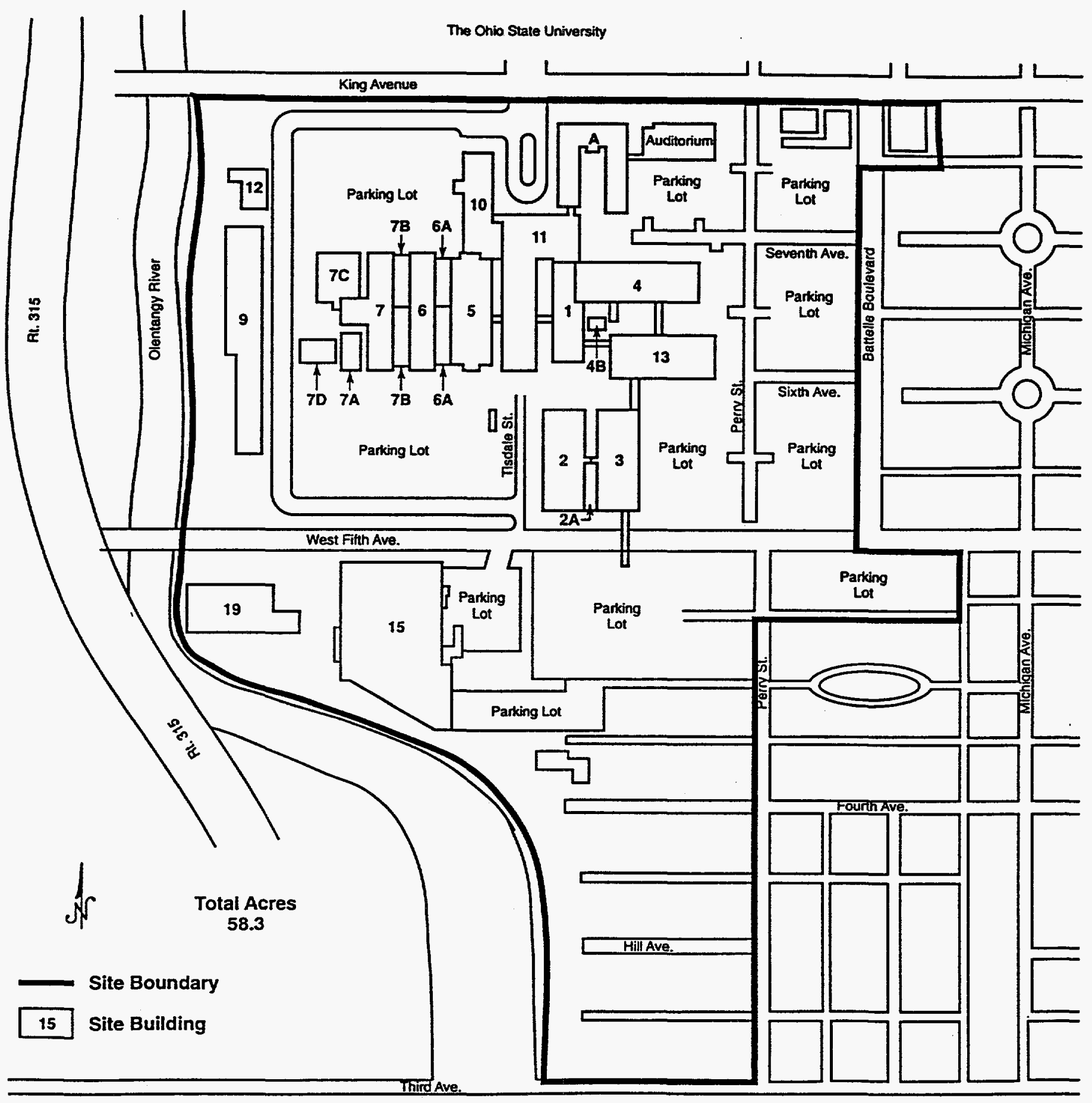

FIGURE 2. LOCAL VICINITY MAP OF KING AVENUE SITE 


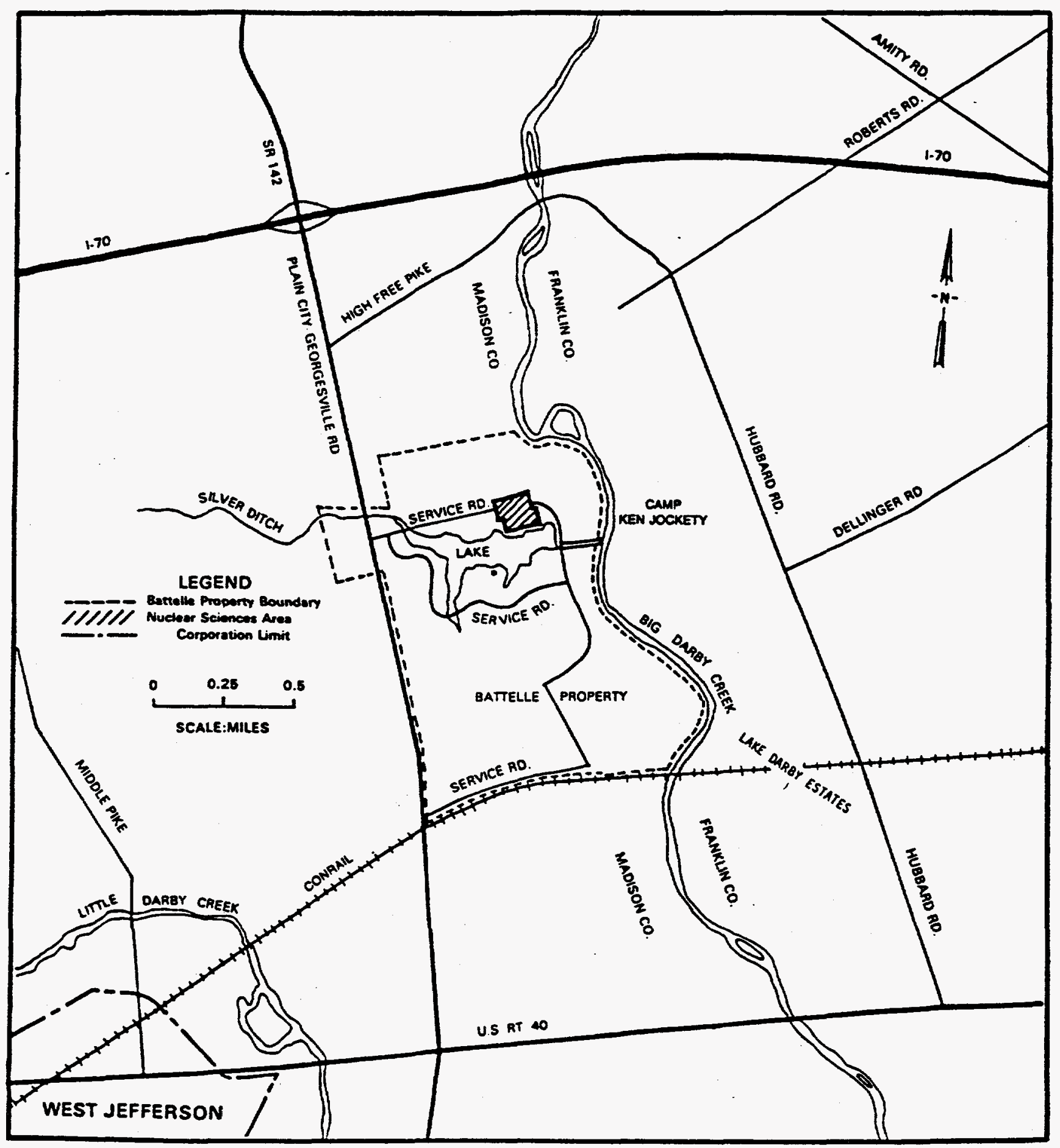

\section{FIGURE 3. LOCAL VICINITY MAP OF NUCLEAR SCIENCES AREA-WEST JEFFERSON SITE}




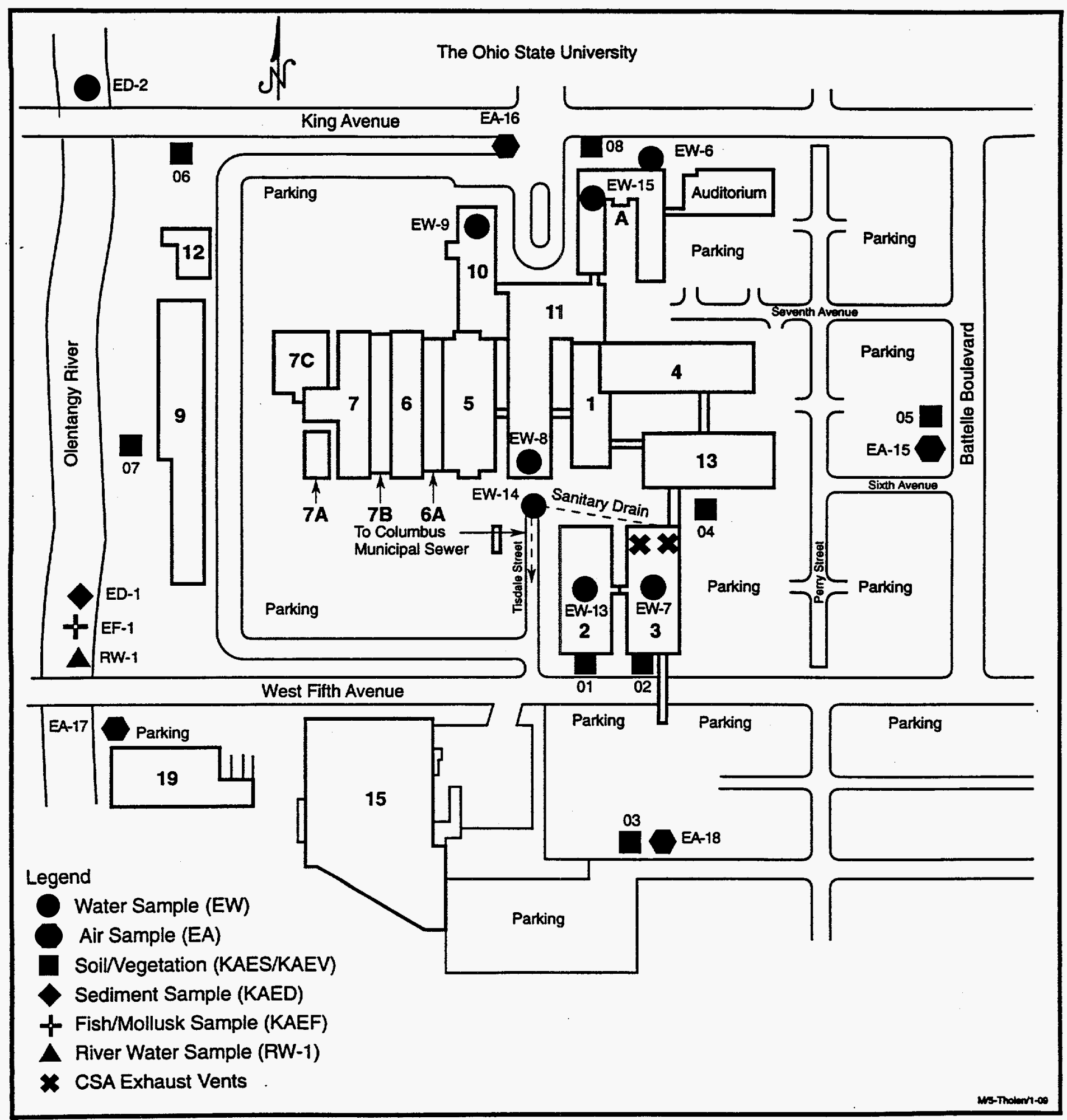

FIGURE 4. BATTELLE KING AVENUE LABORATORIES 


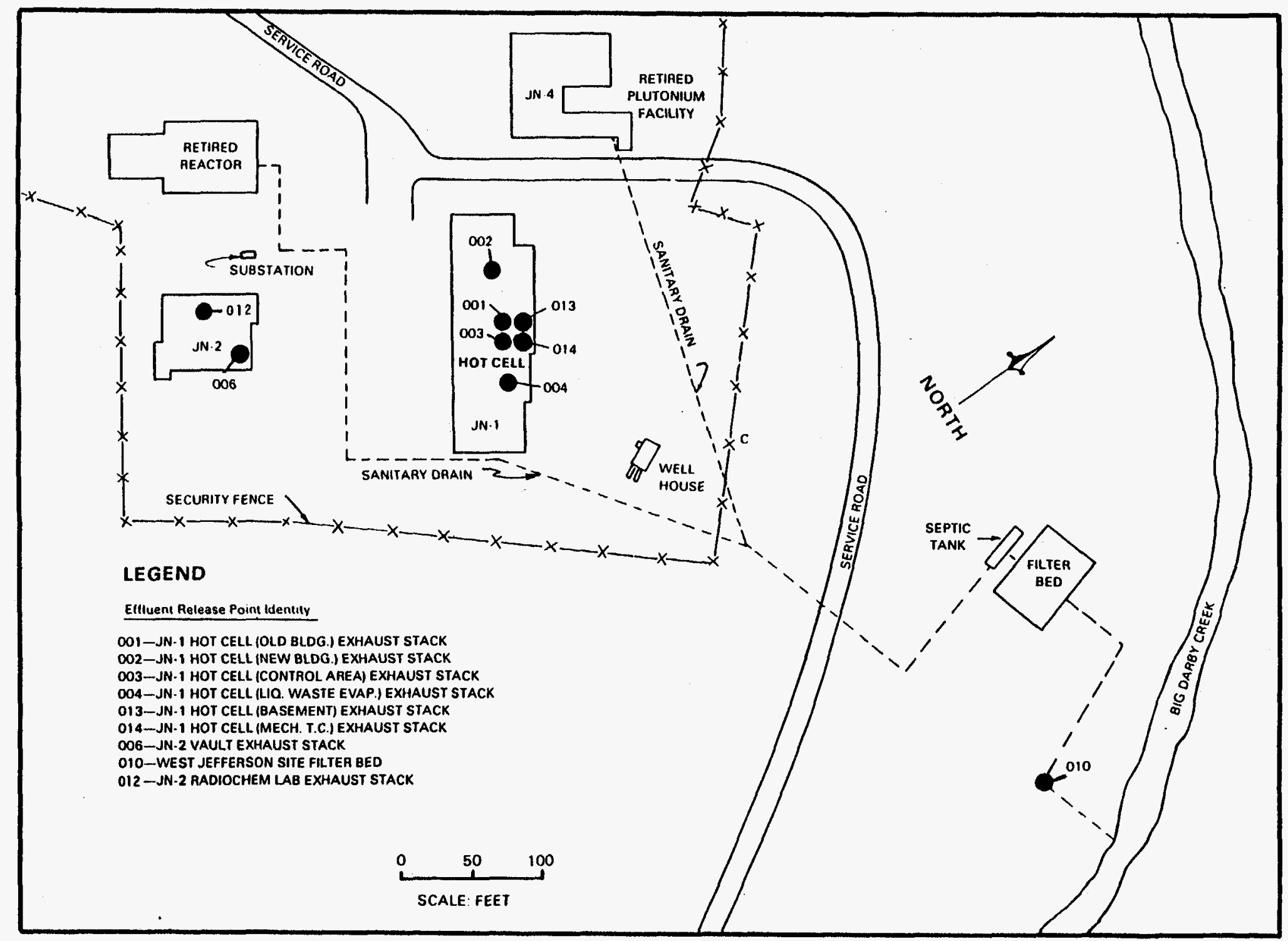




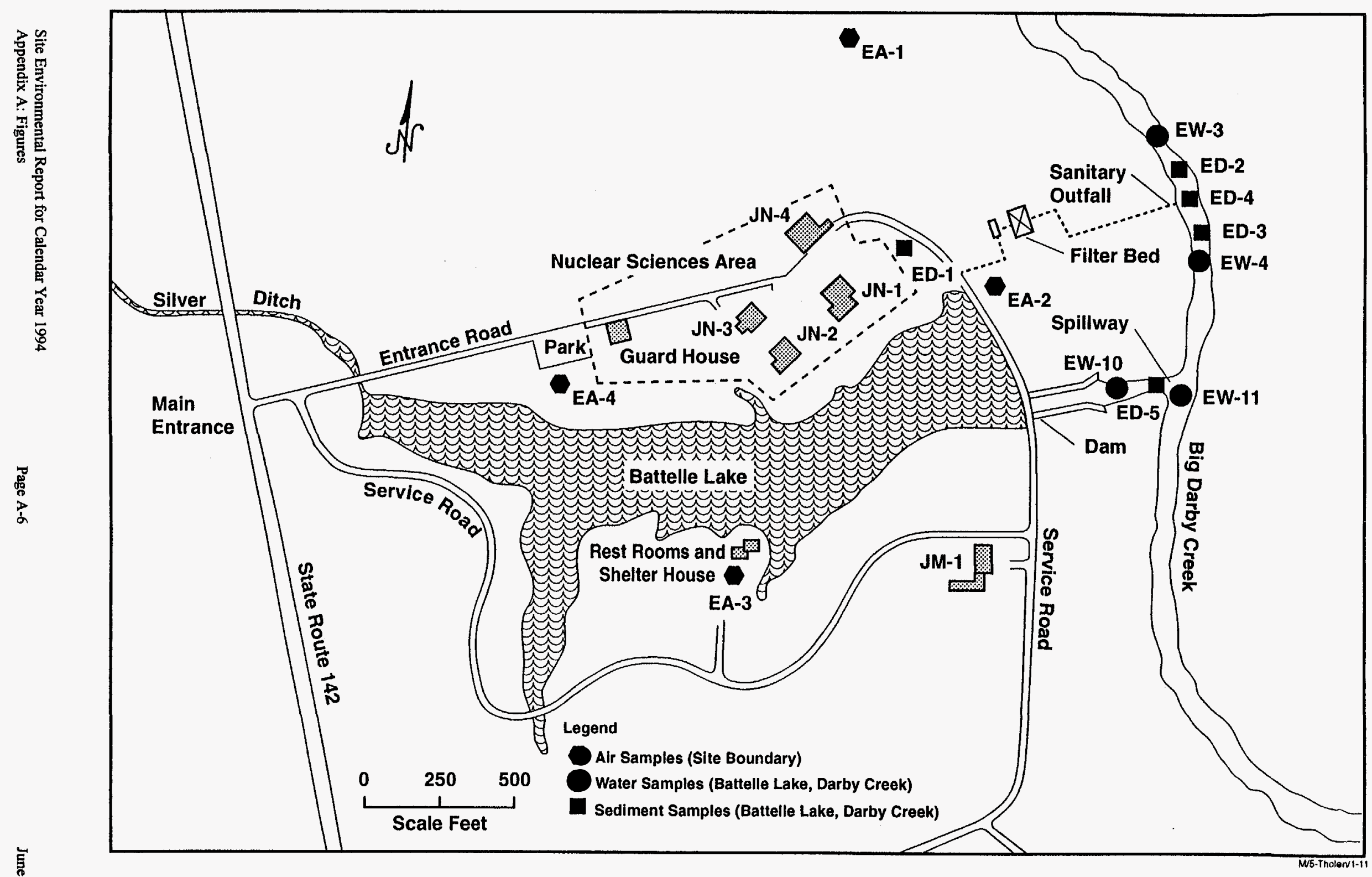

FIGURE 6. MAP OF SITE BOUNDARY AIR SAMPLING LOCATIONS, AND BATTELLE LAKE AND DARBY CREEK WATER AND SEDIMENT SAMPLING LOCATIONS 


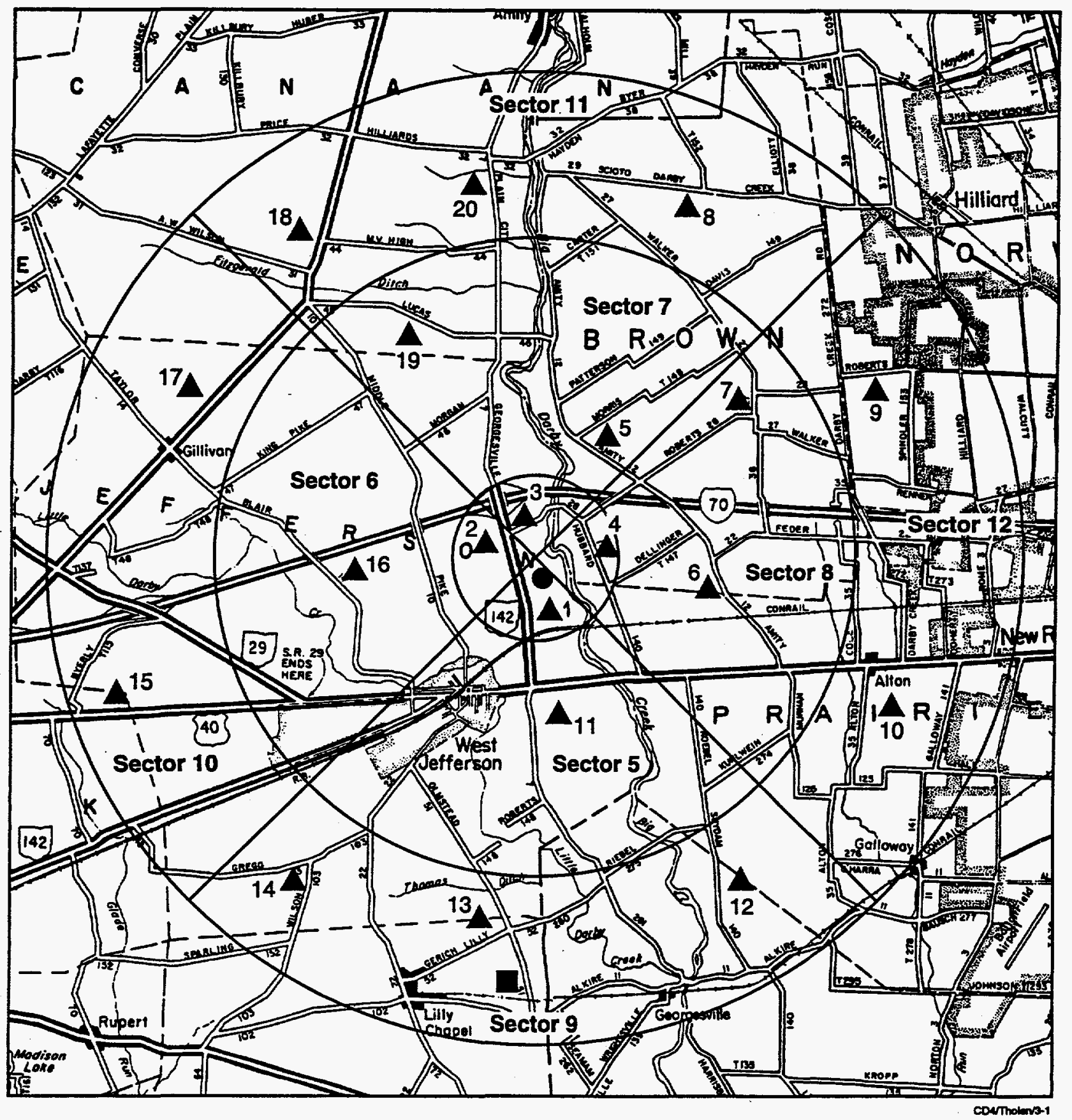

Legend: A Field Crop, Soil, and Vegetation

On-Site Garden Crops

Off-Site Garden Crops

FIGURE 7. MAP OF FIELD CROP, SOIL AND VEGETATION

SAMPLING LOCATIONS-WEST JEFFERSON SITE 


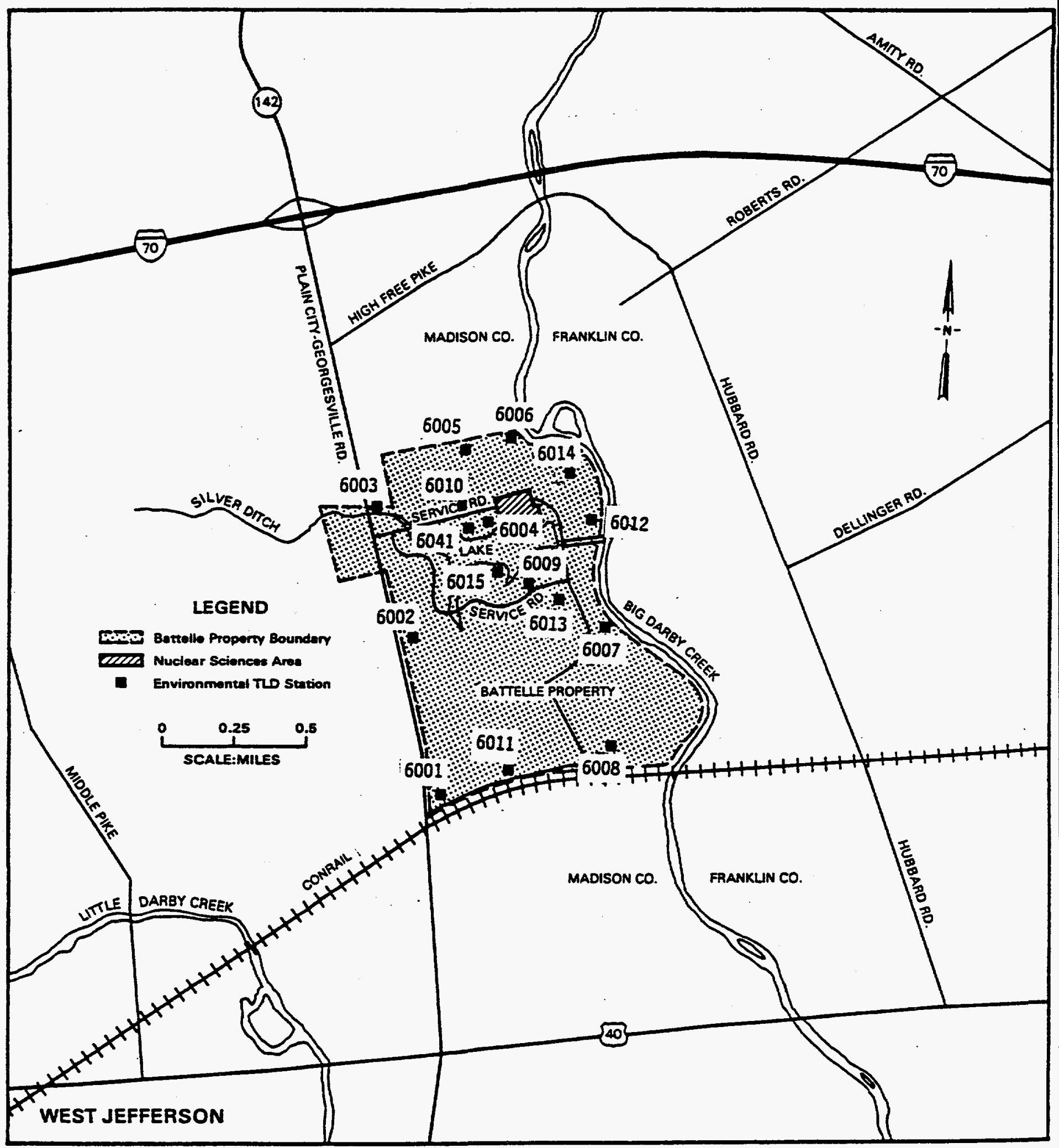

FIGURE 8. MAP OF TLD LOCATIONS WITHIN 3/4-MILE RADIUS OF THE NUCLEAR SCIENCES AREA 


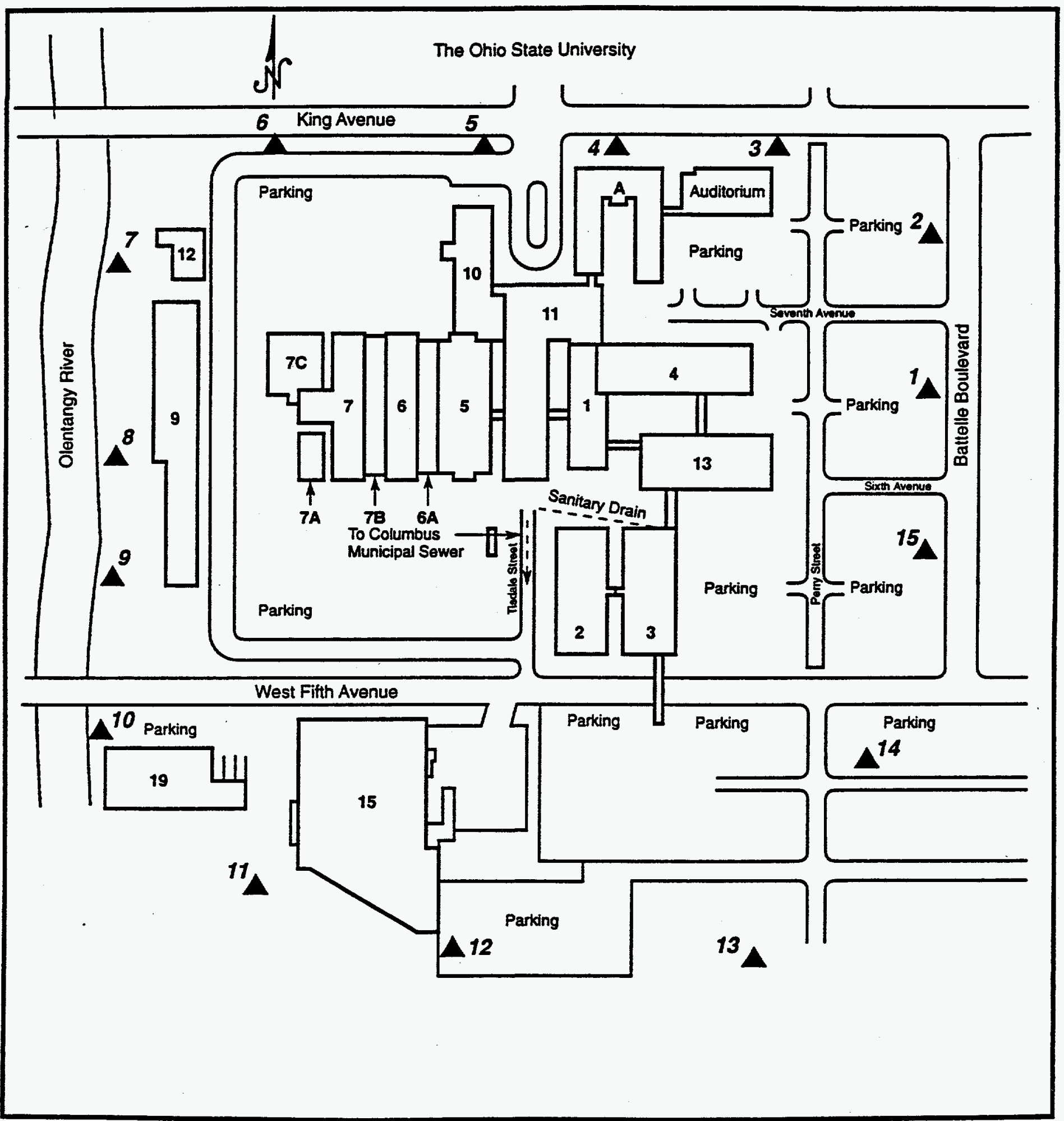

FIGURE 9. KING AVENUE SITE TLD LOCATIONS 


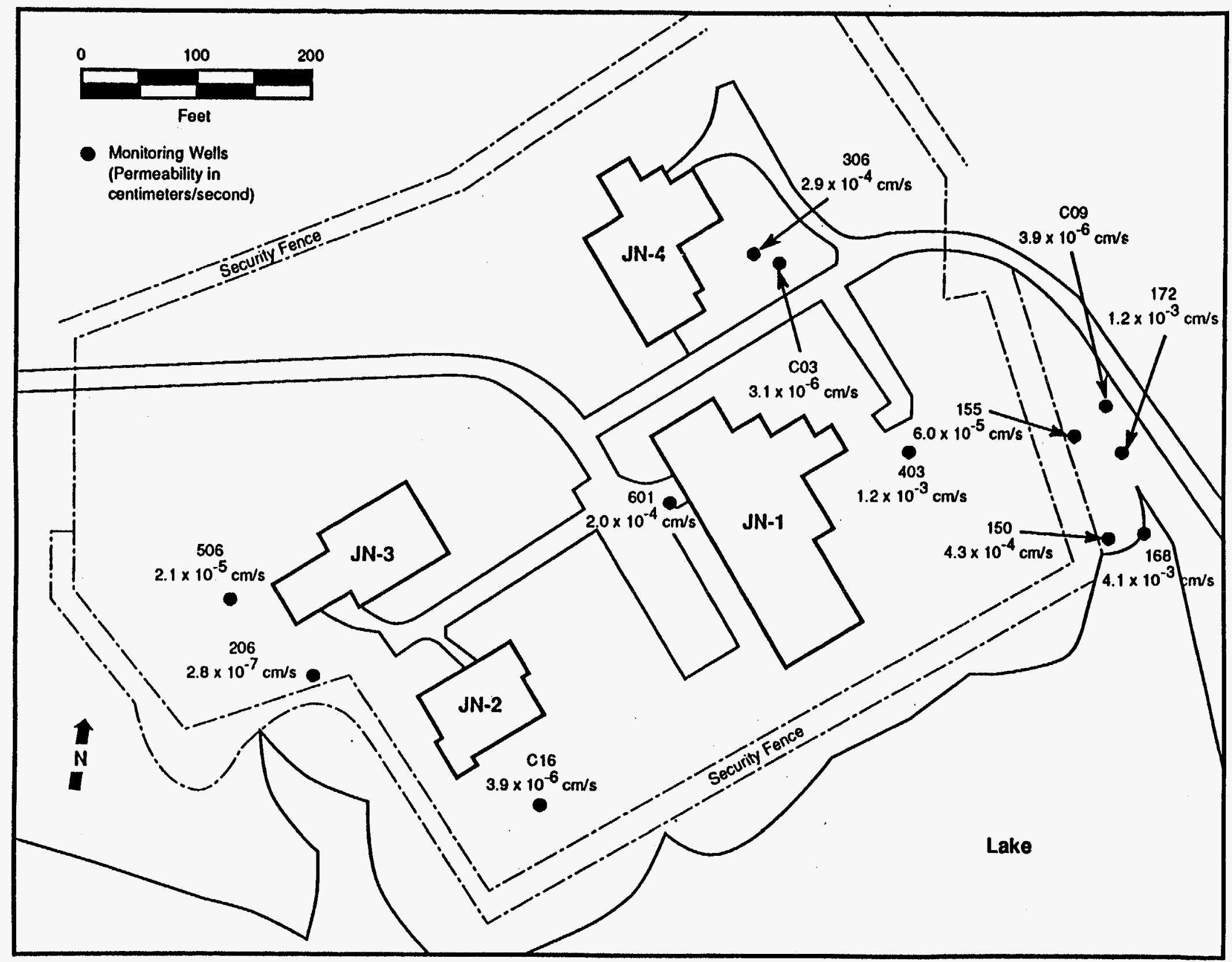

FIGURE 10. NORTH SITE GROUNDWATER MONITORING WELLS 


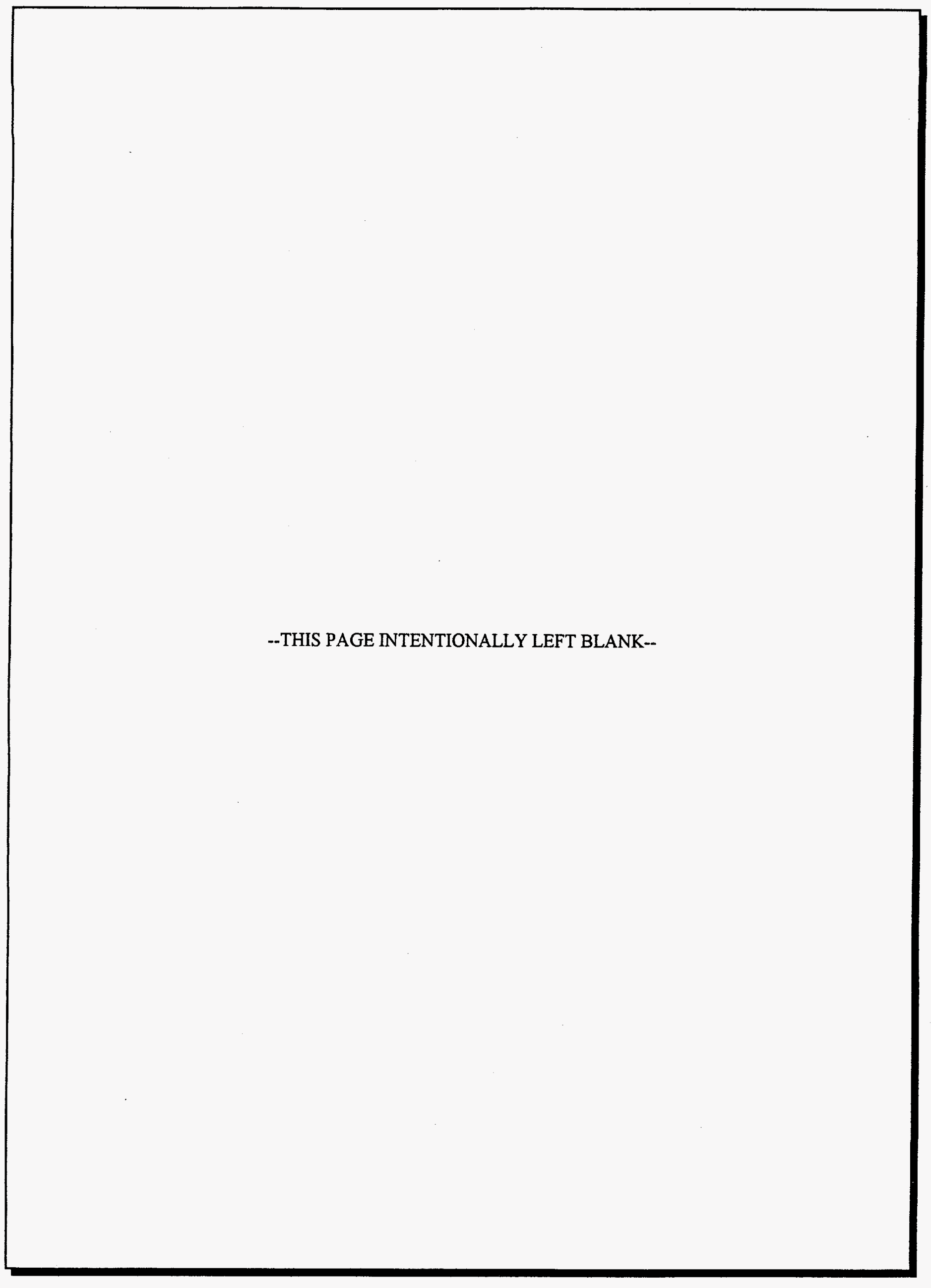




\section{Appendix B Tables}


-THIS PAGE INTENTIONALLY LEFT BLANK-- 


\section{Contents}

\section{Appendix B. List of Tables}

Table 1. Battelle King Avenue Site Population Within 50-Mile Radius

Table 2. Battelle West Jefferson Site Population Within 50 -Mile Radius $\ldots \ldots \ldots \ldots$

Table 3. Annual Radionuclide Release Inventory-West Jefferson Site-1994 .

Table 4. Summary of Atmospheric Radioactive Emissions-West

Jefferson Site-1994

Table 5. Summary of Site Boundary Air Sample Analyses-

West Jefferson Site-1994.

Table 6. Summary of Liquid Radionuclide Emissions-West Jefferson

Site-1994

Table 7. Summary of Alpha/Beta Radiological Analyses of Drinking Water

Samples-West Jefferson and King Avenue Sites-1994

Table 8. Summary of Radiological Analyses of Environmental Water Samples-

West Jefferson Site-1994

Table 9. Summary of Radiological Analyses of Grass-West Jefferson

Site-1994

Table 10. Summary of Radiological Analyses of Field Crops-West

Jefferson Site-1994

Table 11. Summary of Radiological Analyses of Garden Crops-

West Jefferson Site-1994.

Table 12. Summary of Radiological Analyses of Sediment Samples-

West Jefferson Site-1994 . .

Table 13. Summary of Soil Analyses - West Jefferson Site-1994 . . . . . . . . . .

Table 14. Summary of Fish Tissue Analyses-West Jefferson Site-1994

Table 15. Integrated External Background Radiation Measurements at Recreation

Area and Property Boundary Line - West Jefferson Site-1994

Table 16. Summary of Site Boundary Air Sample Analyses

King Avenue Site-1994

B-16

Table 17. Radiological Analyses of Liquid Discharges-King Avenue Site-1994

B-17 


\section{Contents (Continued)}

Table 18. Radiological Analyses of Soil Samples-King Avenue Site-1994 . . . . . . .

Table 19. Radiological Analyses of Vegetation Samples-King Avenue Site-1994 . . . .

Table 20. Radiological Analysis of Sediment Samples-King Avenue Site-1994 . . . . .

Table 21. Radiological Analysis of Olentangy River Water Sample-King Avenue Site-1994

Table 22. Summary of Fish Tissue Analyses-King Avenue Site-1994 . . . . . . .

Table 23. Integrated External Background Radiation Measurements at the Property Line-King Avenue Site-1994

Table 24. Nonradiological Water Effluent Analyses-West Jefferson Site-1994 . . . . .

Table 25. Nonradiological Analyses of Groundwater-West Jefferson Site—1994 . . . . .

Table 26. Summary of Alpha/Beta Radiological Analyses of GroundwaterWest Jefferson Site-1994

Table 27. Summary of Radiological Analyses of Groundwater-West

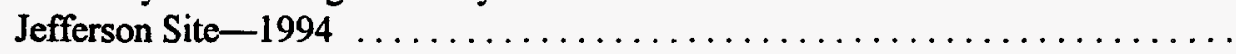

Table 28. Arithmetic Average Wind Speeds and Frequency (Wind Towards) $\ldots \ldots \ldots$

Table 29. Maximum X/Q Dispersion Values at the West Jefferson Site from $\mathrm{JN}-1$ and $\mathrm{JN}-2$ Stacks

Table 30. DOE-EML Quality Assessment Program Results for Battelle Radioanalytical Laboratory (2nd half-1994) . . 
TABLE 1. BATTELLE KING AVENUE SITE POPULATION WITHIN 50-MILE RADIUS ${ }^{(1)}$

\begin{tabular}{|c|c|c|c|c|c|c|c|c|c|c|c|}
\hline Direction. & 0 to 1 & 1 to 2 & 203. & 3 to 4 & 4.0 .5 & 5 to 10 & 10.020 & 20 to 30 . & 30 to 40 . & 40 to 50 & Total \\
\hline NNE. & 2,890 & 12,472 & 12,223 & 9,305 & 9,961 & 69,843 & 32,146 & 7,108 & 9,115 & 12,899 . & 177.962 \\
\hline $\mathrm{Ne}$ & 2,304 & 9,800 & 4,582 & 12,052 & 10,715 & 33,559 & 19,594 & 8,583 & 11,405 & 26,489 & 139,083 \\
\hline E. & 2,379 & 1,105 & 4,986 & 5,327 & 7,225 & 36,093 & 36,855 & 19,378 & 46,659 & 11,822 & 171,829 \\
\hline ESE & 1,134 & 364 & 7,640 & 10,947 & 8,032 & 68,632 & 34,961 & 13,446 & 10,027 & 13,757 & 168,940 \\
\hline SE & 457 & 428 & 5,398 & 15,858 & 8,735 & 14,322 & 12,705 & 41,722 & 13,018 & 15,378 & 128,021 \\
\hline SSE & $0^{(2)}$ & 1,565 & 2,348 & 8,386 & 4,042 & 21,398 & 8,243 & 10,362 & 7,901 & 4,567 & 68.812 \\
\hline $\mathrm{S}$ & $0^{(2)}$ & 3,513 & 3,573 & 1,168 & 758 & 2,783 & 5,905 & 15,197 & 6,738 & 43,264 & 82,899 \\
\hline wsw & 699 & 41 & 2,991 & 7,369 & 4,328 & 30,307 & 3,473 & 11,698 & 5,024 & 20,726 & 86,656 \\
\hline w & 1,534 & 2,600 & 1,316 & 2,225 & 2,327 & 5,477 & 10,245 & 7,340 & 25,726 & 99,540 & 158,330 \\
\hline wNw & 1,046 & 4,706 & 3,913 & 1,082 & 1,964 & 14,483 & 3,634 & 5,161 & 16,047 & 13,706 & 65,742 \\
\hline NW & 82 & 3,972 & 4,742 & 5,617 & 6,143 & 18,169 & 9,512 & 15,678 & 4,592 & 18,042 & 86.549 \\
\hline NNW & 21 & 669 & 702 & 5,487 & 4,489 & 47,202 & 31,149 & 6,090 & 8,483 & 6,158 & 110,450 \\
\hline Total & 14.870 & 56,646 & 75,337 & 114,737 . & 92,747 . & 465,600 & $252,052$. & $206,211$. & 225,092 & 364,420 . & $1,867,712$ \\
\hline
\end{tabular}

(1) 1990 Census of Population and Housing, U.S. Bureau of the Census. Prepared by: Ohio Department of Development (8/92).

(2) Occupied houses do exist within one mile south and southeast of the King Avenue site, however, this data was not included in the 1990 Census. 
TABLE 2. BATTELLE WEST JEFFERSON SITE POPULATION WITHIN 50-MILE RADIUS ${ }^{(1)}$

\begin{tabular}{|c|c|c|c|c|c|c|c|c|c|c|c|}
\hline \multirow[b]{2}{*}{ Direction } & \multicolumn{10}{|c|}{ Distance, miles } & \multirow[b]{2}{*}{ Total } \\
\hline & 0 to 1 & 102 & 2 to 3 & 3 to 4 & 4 to 5 & 5 to 10 & 10 to 20 & 20 to 30 & 30 to 40 & 40 to 50 & \\
\hline $\mathrm{N}$ & 14 & 20 & 87 & 77 & 121 & 3,010 & 4,403 & 49,11 & 9,357 & 48,786 & 70,786 \\
\hline NNE & 8 & 25 & 108 & 90 & 188 & 1,789 & 18,941 & 26,667 & 7,577 & 16,527 & 71.920 \\
\hline NE & 10 & 33 & 48 & 96 & 139 & 17,835 & 101,970 & 13,361 & 9,652 & 14,445 & 157,589 \\
\hline ENE & 10 & 39 & 75 & 192 & 1,239 & 17,796 & 247,639 & 48,962 & 12,038 & 16,592 & 344,582 \\
\hline $\mathrm{E}$ & 150 & 37 & 56 & 273 & 912 & 39,983 & 267,165 & 100,498 & 23,451 & 68,444 & 500,969 \\
\hline ESE & 689 & 166 & 193 & 121 & 376 & 38,556 & 62,298 & 24,406 & 50,876 & 17,140 & 194,821 \\
\hline $\mathrm{SE}$ & 262 & 1,172 & 46 & 71 & 274 & 4,158 & 12,216 & 14,489 & 12,904 & 7,876 & 53.468 \\
\hline SSE & 42 & 257 & 51 & 52 & 78 & 3,158 & 10,623 & 4,625 & 13,120 & 42,261 & 74,267 \\
\hline$S$ & 25 & 84 & 66 & 116 & 123 & 804 & 4,208 & 2,886 & 4,595 & 12,227 & 25,134 \\
\hline ssw & 5 & 497 & 361 & 133 & 80 & 516 & 1,228 & 3,976 & 20,525 & 6,530 & 33,851 \\
\hline sw & 3 & 323 & 2,867 & 596 & 51 & 748 & 978 & 3,650 & 8,110 & 18,019 & 35,345 \\
\hline wsw & 3 & 25 & 290 & 236 & 18 & 951 & 12,858 & 5,606 & 21,156 & 185,260 & 226,403 \\
\hline W & 6 & 24 & 104 & 153 & 110 & 629 & 5,146 & 68,712 & 50,990 & 80,285 & 206,159 \\
\hline WNW & 9 & 14 & 23 & 39 & 67 & 881 & 3,429 & 16,462 & 6,744 & 7,915 & 35,583 \\
\hline NW & 14 & 13 & 31 & 70 & 114 & 357 & 1,464 & 4,736 & 20,819 & 12,691 & 40,309 \\
\hline NNW & 14 & 12 & 45 & 484 & 94 & 665 & 12,097 & 5,189 & 3,851 & 6,905 & 29.356 \\
\hline Total & 1,264 & 2,741 & 4,451 & 2,799 & 3,984 & 131,836 & 766,663 & 349,136 & 275,765 & 561,903 & $2,100,542$ \\
\hline
\end{tabular}

(1) 1990 Census of Population and Housing, U.S. Bureau of the Census. Prepared by: Ohio Department of Development (8/92). 


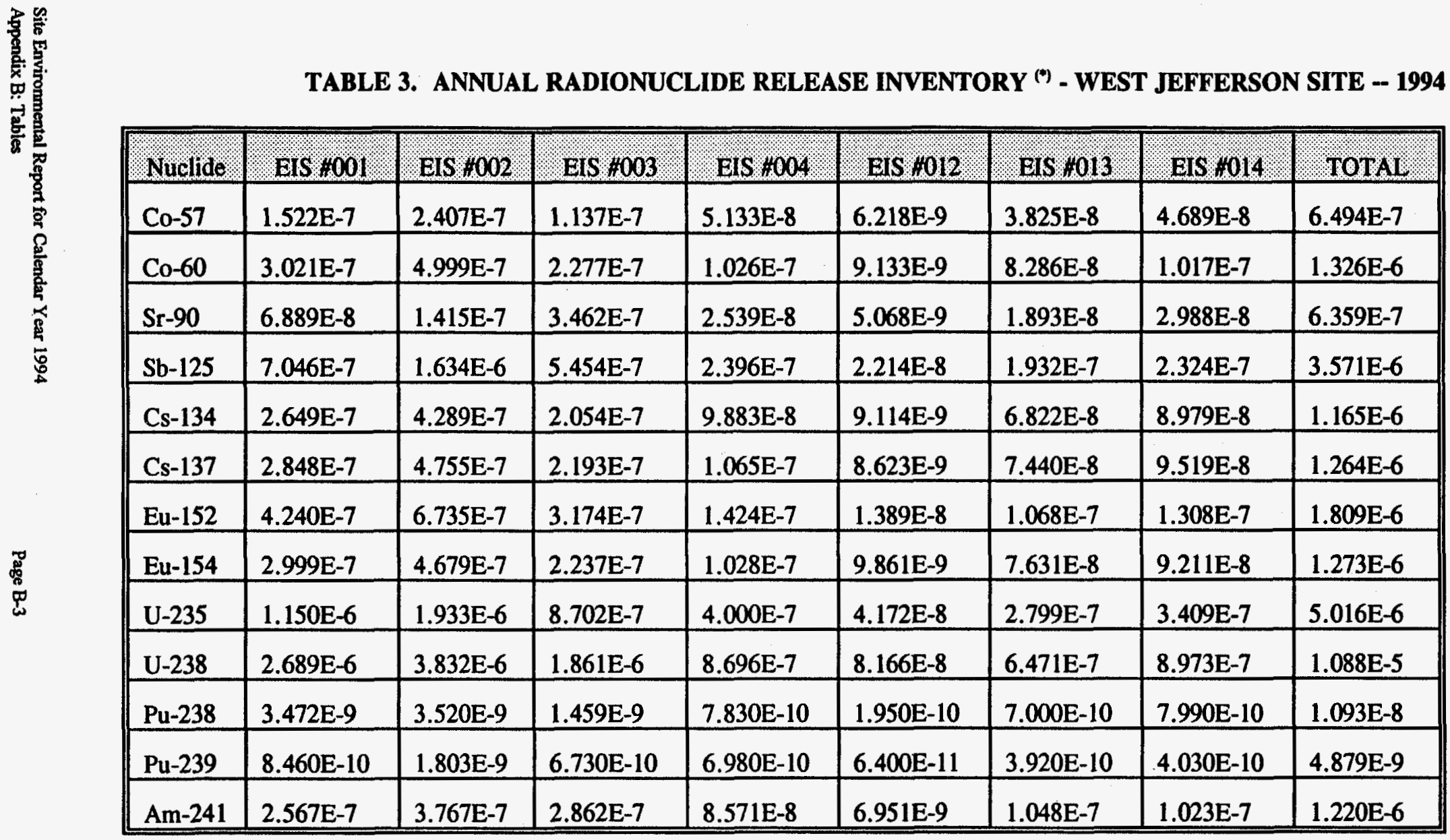

* Total annual radionuclide stack emissions for each EIS point source and total radionuclide air emissions for the West Jefferson North site (expressed in curies/year). 
TABLE 4. ANNUAL AVERAGE RADIONUCLIDE CONCENTRATIONS FROM STACK EMISSIONSWEST JEFFERSON SITE $1994^{(2)}$

\begin{tabular}{|c|c|c|c|c|c|c|c|c|c|c|}
\hline Núclide & EIS H0OL & EIS $\# 002$ & EIS 4003 & EIS 1004 & EIS $\# 012$ & EIS HOLI3 & EIS $\$ 014$ & $\begin{array}{l}\text { Site Boundary } \\
\text { Concentrations }\end{array}$ & $\mathrm{DCG}$ & $\% \mathrm{DCG}$ \\
\hline $\mathrm{Co}-57$ & $5.98 \mathrm{E}-15$ & $2.99 \mathrm{E}-15$ & $2.78 \mathrm{E}-15$ & $2.86 \mathrm{E}-15$ & $3.47 \mathrm{E}-15$ & $2.95 \mathrm{E}-15$ & $2.62 \mathrm{E}-15$ & $1.41 \mathrm{E}-19$ & 2E-9 & $7.05 \mathrm{E}-9$ \\
\hline $\mathrm{Co}-60$ & $1.19 \mathrm{E}-14$ & $6.02 \mathrm{E}-15$ & $5.57 \mathrm{E}-15$ & $5.73 \mathrm{E}-15$ & $5.10 \mathrm{E}-15$ & $6.38 \mathrm{E}-15$ & $5.68 \mathrm{E}-15$ & $2.82 \mathrm{E}-19$ & $8 \mathrm{E}-11$ & $3.53 \mathrm{E}-7$ \\
\hline Sr-90 & $2.71 \mathrm{E}-15$ & $1.76 \mathrm{E}-15$ & $8.47 \mathrm{E}-15$ & $1.42 \mathrm{E}-15$ & $2.83 \mathrm{E}-15$ & $1.46 \mathrm{E}-15$ & $1.67 \mathrm{E}-15$ & $1.51 \mathrm{E}-19$ & $9 \mathrm{E}-12$ & $1.68 \mathrm{E}-6$ \\
\hline $\mathrm{Sb}-125$ & $2.77 \mathrm{E}-14$ & $2.03 \mathrm{E}-14$ & 1.33E-14 & $1.34 \mathrm{E}-14$ & $1.24 \mathrm{E}-14$ & $1.49 \mathrm{E}-14$ & $1.30 \mathrm{E}-14$ & $6.84 \mathrm{E}-19$ & $1 \mathrm{E}-9$ & $6.84 \mathrm{E}-8$ \\
\hline Cs-134 & $1.04 \mathrm{E}-14$ & 5.32E-15 & $5.02 \mathrm{E}-15$ & $5.49 \mathrm{E}-15$ & $5.09 \mathrm{E}-15$ & $5.26 \mathrm{E}-15$ & $5.01 \mathrm{E}-14$ & 2.52E-19 & $2 \mathrm{E}-10$ & $1.26 \mathrm{E}-7$ \\
\hline Cs-137 & $1.12 \mathrm{E}-14$ & $5.90 \mathrm{E}-15$ & $5.36 \mathrm{E}-15$ & $5.94 \mathrm{E}-15$ & $4.82 \mathrm{E}-15$ & $5.73 \mathrm{E}-15$ & $5.31 \mathrm{E}-15$ & $2.72 \mathrm{E}-19$ & $4 \mathrm{E}-10$ & $6.80 \mathrm{E}-8$ \\
\hline $\mathrm{Eu}-152$ & $1.67 \mathrm{E}-14$ & 8.36E-15 & $7.76 \mathrm{E}-15$ & $7.95 \mathrm{E}-15$ & $7.76 \mathrm{E}-15$ & $8.23 \mathrm{E}-15$ & $7.30 \mathrm{E}-15$ & $3.83 \mathrm{E}-19$ & $5 \mathrm{E}-11$ & $7.66 \mathrm{E}-7$ \\
\hline Eu-154 & $1.18 \mathrm{E}-14$ & $5.81 \mathrm{E}-15$ & $5.47 \mathrm{E}-15$ & $5.74 \mathrm{E}-15$ & $5.51 \mathrm{E}-15$ & $5.88 \mathrm{E}-15$ & $5.14 \mathrm{E}-15$ & $2.52 \mathrm{E}-19$ & $5 \mathrm{E}-11$ & $5.04 \mathrm{E}-7$ \\
\hline $\mathrm{U}-235$ & 4.52E-14 & $2.40 \mathrm{E}-14$ & $2.13 \mathrm{E}-14$ & $2.23 \mathrm{E}-14$ & $2.33 \mathrm{E}-14$ & $2.16 \mathrm{E}-14$ & $1.90 \mathrm{E}-14$ & $1.01 \mathrm{E}-18$ & $1 \mathrm{E}-13$ & $1.01 \mathrm{E}-3$ \\
\hline $\mathrm{U}-238$ & $1.06 \mathrm{E}-13$ & $4.75 \mathrm{E}-14$ & $4.55 \mathrm{E}-14$ & $4.85 \mathrm{E}-14$ & $4.56 \mathrm{E}-14$ & $4.99 \mathrm{E}-14$ & 5.01E-14 & $2.42 \mathrm{E}-18$ & $3 \mathrm{E}-14$ & 8.07E-3 \\
\hline $\mathrm{Pu}-238$ & $1.36 \mathrm{E}-16$ & 4.37E-17 & 3.57E-17 & 4.37E-17 & $1.09 \mathrm{E}-16$ & $5.40 \mathrm{E}-17$ & $4.46 \mathrm{E}-17$ & $2.44 \mathrm{E}-21$ & $3 E-14$ & $8.13 \mathrm{E}-6$ \\
\hline Pu-239 & $3.32 \mathrm{E}-17$ & $2.24 \mathrm{E}-17$ & $1.65 \mathrm{E}-17$ & $3.89 \mathrm{E}-17$ & $3.60 \mathrm{E}-17$ & $3.02 \mathrm{E}-17$ & $2,25 \mathrm{E}-17$ & $1.01 \mathrm{E}-21$ & 2E-14 & $5.05 \mathrm{E}-6$ \\
\hline$A m-241$ & $1.01 \mathrm{E}-14$ & $4.67 \mathrm{E}-15$ & $7.00 \mathrm{E}-15$ & $4.78 \mathrm{E}-15$ & $3.88 \mathrm{E}-15$ & $8.08 \mathrm{E}-15$ & $5.71 \mathrm{E}-15$ & $1.91 \mathrm{E}-19$ & $2 \mathrm{E}-14$ & $9.55 \mathrm{E}-4$ \\
\hline $\begin{array}{l}\text { Release } \\
\text { Rate } \\
(\mathrm{m} / \mathrm{s})\end{array}$ & 24.89 & 35.05 & 17.78 & 17.53 & 20.83 & 17.53 & 12.70 & & & \\
\hline $\begin{array}{l}\text { Volume } \\
\text { (mL/yr) }\end{array}$ & $2.55 \mathrm{E}-13$ & $8.06 \mathrm{E}-13$ & $4.09 \mathrm{E}-13$ & $1.79 \mathrm{E}-13$ & $1.79 \mathrm{E}-12$ & $1.30 \mathrm{E}-13$ & $1.79 \mathrm{E}-13$ & & & \\
\hline
\end{tabular}

(a) Stack data representing annual average radionuclide concentrations (expressed in $\mu \mathrm{Ci} / \mathrm{mL}$ ) for EIS effluent point source.

(b) Site boundary radionuclide concentrations reflect CAP88PC air dispersion modeling calculations (expressed in $\mu \mathrm{Ci} / \mathrm{mL}$ ). 
TABLE 5. SUMMARY OF SITE BOUNDARY AIR SAMPLE ANALYSES WEST JEFFERSON SITE - 1994

\begin{tabular}{|c|c|c|c|c|}
\hline Nuclide & $\mathrm{EA}-1$ ( $(\mu \mathrm{C} / \mathrm{m}$ (m) & $\mathrm{EA}-2(\mu \mathrm{Cl} / \mathrm{mil})$ & $\mathrm{EA}-3(\mu \mathrm{Gi} / \mathrm{ml})$ & 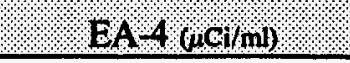 \\
\hline Gross Alpha & $1.40 \mathrm{E}-15 \pm 5.5 \mathrm{E}-16$ & $1.40 \mathrm{E}-15 \pm 5.52 \mathrm{E}-16$ & $1.41 \mathrm{E}-15 \pm 5.60 \mathrm{E}-16$ & $1.47 \mathrm{E}-15 \pm 5.80 \mathrm{E}-16$ \\
\hline Gross Beta & $1.23 \mathrm{E}-14 \pm 1.11 \mathrm{E}-15$ & $1.26 \mathrm{E}-14 \pm 1.14 \mathrm{E}-15$ & $1.31 \mathrm{E}-14 \pm 1.16 \mathrm{E}-15$ & $1.40 \mathrm{E}-14 \pm 1.21 \mathrm{E}-15$ \\
\hline $\mathrm{Co}-57$ & 3.07E-16 & $3.59 \mathrm{E}-16$ & 3.03E-16 & $3.13 E-16$ \\
\hline $\mathrm{C} 0-60$ & $5.41 \mathrm{E}-16$ & $1.78 \mathrm{E}-15$ & $6.03 E-16$ & $5.36 \mathrm{E}-16$ \\
\hline Sr-90 & $5.72 \mathrm{E}-16$ & $5.56 \mathrm{E}-16$ & $1.13 \mathrm{E}-15$ & $5.67 \mathrm{E}-16$ \\
\hline $\mathrm{Sb}-125$ & $1.29 \mathrm{E}-15$ & $1.44 \mathrm{E}-15$ & $1.36 \mathrm{E}-15$ & $1.38 \mathrm{E}-15$ \\
\hline Cs-134 & $5.18 \mathrm{E}-16$ & $5.02 \mathrm{E}-16$ & $4.95 \mathrm{E}-16$ & $5.50 \mathrm{E}-16$ \\
\hline Cs- 137 & $5.06 \mathrm{E}-16$ & $5.19 \mathrm{E}-16$ & $4.99 \mathrm{E}-16$ & $5.48 \mathrm{E}-16$ \\
\hline $\mathrm{Eu}-152$ & $7.46 \mathrm{E}-16$ & $8.52 \mathrm{E}-16$ & $7.32 \mathrm{E}-16$ & $7.46 \mathrm{E}-16$ \\
\hline Eu-154 & $5.20 \mathrm{E}-16$ & $6.10 \mathrm{E}-16$ & $5.17 \mathrm{E}-16$ & $5.31 \mathrm{E}-16$ \\
\hline U-235 & $2.29 \mathrm{E}-15$ & $2.59 \mathrm{E}-15$ & $2.27 \mathrm{E}-15$ & $2.27 \mathrm{E}-15$ \\
\hline $\mathrm{U}-235(\mathrm{pg} / \mathrm{ml})$ & 0.107 & 0.121 & 0.106 & $1.06 \mathrm{E}-3$ \\
\hline $\mathrm{U}-238$ & $4.39 \mathrm{E}-15$ & $4.91 \mathrm{E}-15$ & $4.92 \mathrm{E}-15$ & $4.86 \mathrm{E}-15$ \\
\hline $\mathrm{U}-238(\mathrm{pg} / \mathrm{ml})$ & 0.013 & 0.015 & 0.015 & 0.015 \\
\hline $\mathrm{Pu}-238$ & 4.32E-17 & $1.36 \mathrm{E}-17$ & $1.42 \mathrm{E}-17$ & $1.04 \mathrm{E}-17$ \\
\hline Pu-239 & $7.76 \mathrm{E}-18$ & $6.65 \mathrm{E}-18$ & $5.10-18$ & $9.51 \mathrm{E}-18$ \\
\hline Am-241 & $3.63 \mathrm{E}-16$ & 4.37E-16 & $7.26 \mathrm{E}-16$ & $7.26 \mathrm{E}-16$ \\
\hline Nat-U & $7.76 \mathrm{E}-17$ & $8.35 \mathrm{E}-17$ & $8.87 \mathrm{E}-17$ & $8.46 \mathrm{E}-17$ \\
\hline Nat-II $(\mathrm{pg} / \mathrm{ml}$ & $115 \mathrm{E}-4$ & $123 \mathrm{E}-46$ & $131 \mathrm{E}-4$ & $125 \mathrm{E}-4$ \\
\hline
\end{tabular}

(a) Locations are shown in Figure 6. North Quadrant Station (137.2 m north of JN-4 stacks); East Quadrant Station (21.9 $\mathrm{m}$ east of JN-1 stacks); South Quadrant Station (228.6 m south of JN-2 stacks); West Quadrant Station (121.9 m west of JN-2 stacks).

(b) All isotopic values represent average MDL values (a posteriori). U-235, U-238, and Am-241 associated $\gamma$ produce higher MDL values than gross $\alpha$ and $\beta$ results would indicate. Gross $\alpha \mathrm{MDL}$ is $3.0 \times 10^{-16} \mu \mathrm{Ci} / \mathrm{ml}$ and gross $\beta \mathrm{MDL}$ is $6.0 \times 10^{-16} \mu \mathrm{Ci} / \mathrm{ml}(\mathrm{a}$ priori).

(c) Detection limit is 4.66 multiplied by the standard deviation of the background, divided by the efficiency, assuming a 50 percent recovery of the spike, and a flow volume of $2.7 \mathrm{E}+9 \mathrm{ml}$. 
TABLE 6. SUMMARY OF LIQUID RADIONUCLIDE EMISSIONS

WEST JEFFERSON SITE ${ }^{(a)}-1994$

\begin{tabular}{|c|c|c|c|c|c|c|c|}
\hline Wuclide & $\begin{array}{l}\text { Number } \\
\text { Samples. } \\
\text { Sam }\end{array}$ & Activity, & $\begin{array}{l}\text { Average Concentration. } \\
\text { uCilmil }\end{array}$ & \multicolumn{3}{|c|}{ DCG, $\mu \mathrm{Ci} / \mathrm{ml}$} & $\begin{array}{l}\text { Percentage } \\
\text { of DCG, \% }\end{array}$ \\
\hline Gross $\alpha$ & 52 & - & $(6.56 \pm 3.36) \times 10^{-9}$ & \multicolumn{3}{|c|}{-} & $-^{(c)}$ \\
\hline Gross $\beta$ & 52 & - & $(11.37 \pm 1.28) \times 10^{-9}$ & \multicolumn{3}{|c|}{-} & - \\
\hline $\mathrm{Co}-57$ & 12 & 29.2 & $1.96 \times 10^{-9}$ & 1.0 & $\mathbf{x}$ & $10^{-4}$ & 0.00 \\
\hline $\mathrm{Co}-60$ & 12 & 35.6 & $2.39 \times 10^{-9}$ & 5.0 & $\mathbf{x}$ & $10^{-6}$ & 0.05 \\
\hline Sr-90 & 12 & 10.8 & $7.25 \times 10^{-10}$ & 1.0 & $\mathbf{x}$ & $10^{-6}$ & 0.07 \\
\hline $\mathrm{Sb}-125$ & 12 & 100.4 & $6.74 \times 10^{-9}$ & 5.0 & $\mathbf{x}$ & $10^{-5}$ & 0.01 \\
\hline Cs-134 & 12 & 34.9 & $2.34 \times 10^{-9}$ & 2.0 & $\mathbf{x}$ & $10^{-6}$ & 0.12 \\
\hline Cs- 137 & 12 & 38.9 & $2.61 \times 10^{-9}$ & 3.0 & $\mathbf{x}$ & $10^{-6}$ & 0.09 \\
\hline Eu-152 & 12 & 83.9 & $5.63 \times 10^{-9}$ & 2.0 & $\mathbf{x}$ & $10^{-5}$ & 0.03 \\
\hline Eu-154 & 12 & 59.1 & $3.97 \times 10^{-9}$ & 2.0 & $\mathbf{x}$ & $10^{-5}$ & 0.02 \\
\hline $\mathrm{Ra}-226$ & 12 & 27.3 & $1.31 \times 10^{-9}$ & 1.0 & $\mathbf{x}$ & $10^{-7}$ & 1.31 \\
\hline $\mathrm{Ra}-228$ & 12 & 30.8 & $1.48 \times 10^{-9}$ & 1.0 & $x$ & $10^{-7}$ & 1.48 \\
\hline I-129 & 12 & 162.3 & $7.77 \times 10^{-9}$ & 5.0 & $\mathbf{x}$ & $10^{-7}$ & 1.55 \\
\hline $\mathrm{U}-235$ & 12 & 180.5 & $1.21 \times 10^{-8}$ & 6.0 & $\mathbf{x}$ & $10^{-7}$ & 2.02 \\
\hline $\mathrm{U}-235^{\dagger}$ & 12 & $8.4 \times 10^{3} \mathrm{~g} / \mathrm{yr}$ & $5.65 \times 10^{-1}$ & \multicolumn{3}{|c|}{$28.0 \times 10^{1} \mathrm{~g} / \mathrm{yr}$} & \\
\hline $\mathrm{U}-238$ & 12 & 914.5 & $6.14 \times 10^{-8}$ & 6.0 & $x$ & $10^{-7}$ & $10.23^{(\mathrm{d})}$ \\
\hline$U-238^{\dagger}$ & 12 & $2.8 \times 10^{3} \mathrm{~g} / \mathrm{yr}$ & $1.84 \times 10^{-1}$ & \multicolumn{3}{|c|}{$1.8 \times 10^{1} \mathrm{~g} / \mathrm{yr}$} & \\
\hline $\mathrm{Pu}-238$ & 12 & 1.0 & $6.62 \times 10^{-11}$ & 4.0 & $\mathbf{x}$ & $10^{-8}$ & 0.17 \\
\hline Pu-239 & 12 & 0.4 & $2.88 \times 10^{-11}$ & 3.0 & $\mathbf{x}$ & $10^{-8}$ & 0.10 \\
\hline Am-241 & 12 & 113.9 & $7.64 \times 10^{-9}$ & 3.0 & $\mathbf{x}$ & $10^{-8}$ & $25.48^{(\mathrm{d})}$ \\
\hline Nat-U & 4 & 21.9 & $1.47 \times 10^{-9}$ & 6.0 & $\mathbf{x}$ & $10^{-7}$ & 0.24 \\
\hline Nat- $U^{+}$ & 4 & $3.4 \times 10^{1} \mathrm{~g} / \mathrm{yr}$ & $2.17 \times 10^{-3}$ & \multicolumn{3}{|c|}{$8.9 \times 10^{-1} \mathrm{~g} / \mathrm{yr}$} & \\
\hline
\end{tabular}

(a) Annual average flow in Big Darby Creek; $429 \mathrm{cu} \mathrm{ft} / \mathrm{sec}=3.82 \times 10^{11} \mathrm{~V} / \mathrm{yr}$. Total volume of liquid effluent discharge for $1994=1.49 \times 10^{7} 1$. See Figure 5 for sample location 010 .

(b) Isotopic data for effluents released at this location were obtained from gamma and radiochemical analysis of monthly composite samples where possible. In the absence of detectable activity, calculated MDL values (a posteriori) were used to establish inventory on suspected radionuclides. Gross $\alpha$ values were used for alpha emitters U-238 and Am-241 using a conservative $100 \%$ of $\alpha$ activity.

(c) No DCG listing for mixture of gross $\alpha$ and $\beta$. Value represents percent of total activity using 10 CFR Part 20, Appendix B limit $\left(3 \times 10^{-5}\right)$ for mixture, not containing Sr-90, I-129, Ra-226, and Ra-228.

(d) As discussed in the text, these values are calculated from MDL values.

$+\mu \mathrm{g} / \mathrm{ml}$ 
TABLE 7. SUMMARY OF ALPHA/BETA RADIOLOGICAL ANALYSES OF DRINKING WATER SAMPLES

WEST JEFFERSON AND KING AVENUE SITES - 1994

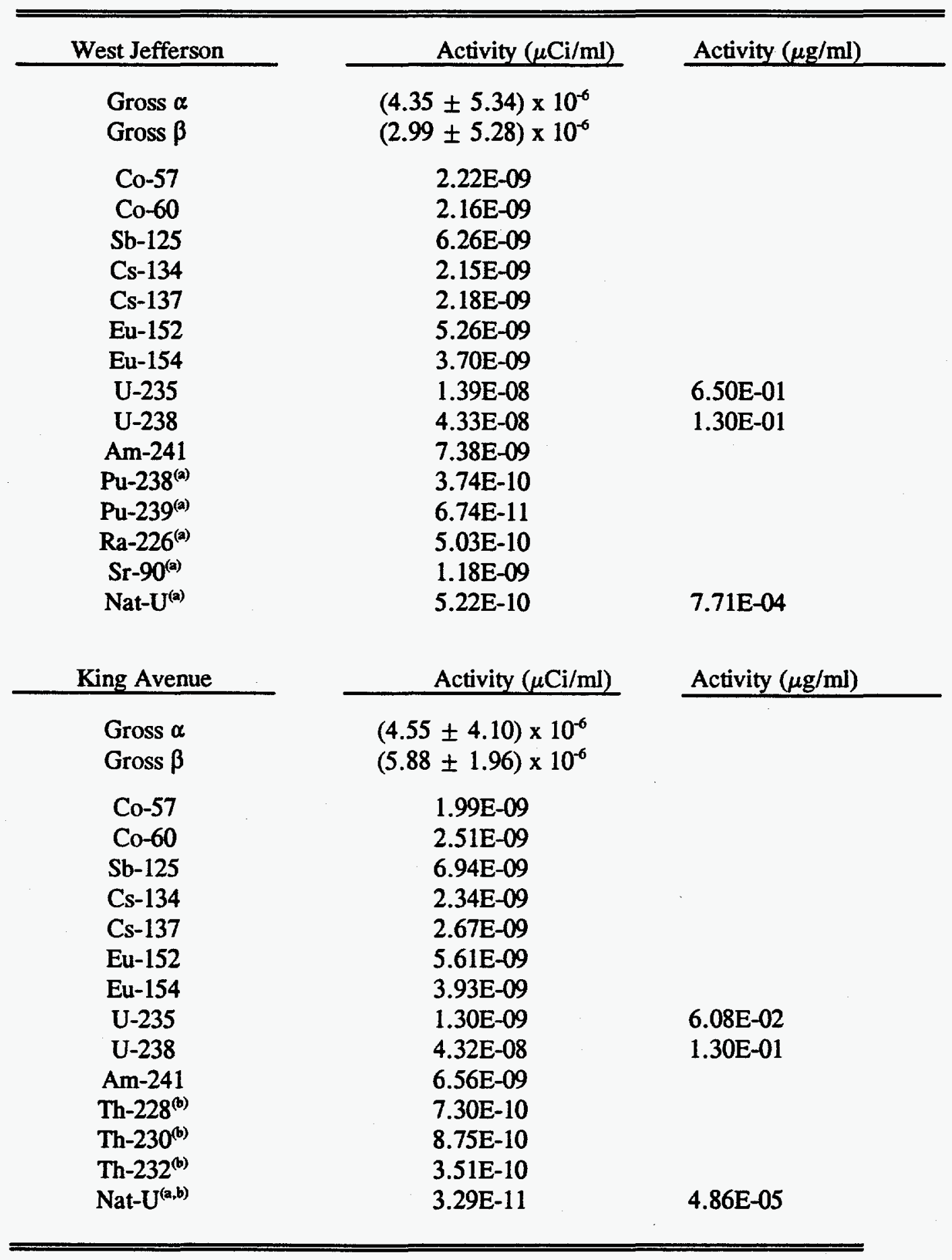

All values are actual MDAs

(a) Denotes analysis on annual composite only.

(b) Denotes analysis on quarterly composite only. 


\section{TABLE 8. SUMMARY OF RADIOLOGICAL ANALYSES OF ENVIRONMENTAL WATER SAMPLES WEST JEFFERSON SITE - 1994}

\begin{tabular}{|c|c|c|c|}
\hline 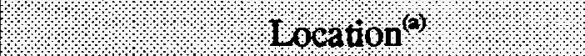 & & \multicolumn{2}{|c|}{$10^{-} \mu \mathrm{Cl} / \mathrm{ml}^{\circ}$} \\
\hline $\begin{array}{l}\text { (Direction and Distance } \\
\text { from Nuclear Sciences Area) }\end{array}$ & $\begin{array}{l}\text { Number of } \\
\text { Samples }\end{array}$ & Gross $\alpha$ & Gross B \\
\hline $\begin{array}{l}\text { Big Darby Creek Upstream } \\
\text { (18.3 } \mathrm{m} \text { above sanitary outfall) }\end{array}$ & 12 & $5.55 \pm 5.42$ & $6.86 \pm 2.10$ \\
\hline $\begin{array}{l}\text { Big Darby Creek Downstream } \\
\text { (18.3 m below sanitary outfall) }\end{array}$ & 12 & $4.43 \pm 5.26$ & $6.39 \pm 2.10$ \\
\hline $\begin{array}{l}\text { Big Darby Creek Downstream } \\
\text { (186.3 m below sanitary outfall) }\end{array}$ & 12 & $6.91 \pm 5.70$ & $5.52 \pm 1.96$ \\
\hline $\begin{array}{l}\text { Battelle Lake Spillway } \\
\text { (18.3 } \mathrm{m} \text { below dam) }\end{array}$ & 12 & $4.14 \pm 4.12$ & $5.22 \pm 1.90$ \\
\hline
\end{tabular}

(a) Locations are shown in Figure 6.

(b) Big Darby Creek and Battelle Lake Spillway samples are monthly composite samples of weekly collections.

(c) A priori minimum detection limit is $6.5 \times 10^{-9} \mu \mathrm{Ci} / \mathrm{ml}$ for gross $\alpha$ and $4.8 \times 10^{-9} \mu \mathrm{Ci} / \mathrm{ml}$ for gross $\beta$ 
TABLE 9. SUMMARY OF RADIOLOGICAL ANALYSES OF GRASS - WEST JEFFERSON SITE - 1994

$\mathrm{pCi} / \mathrm{g}$ dry weight

All values are less than MDA values except where indicated (*)

\begin{tabular}{|c|c|c|c|c|c|c|c|c|c|c|c|c|}
\hline \multirow[b]{2}{*}{ Nuclide } & \multicolumn{12}{|c|}{ Identification No } \\
\hline & $v^{\text {Sector }}$ & $\mathrm{Sector}_{2}$ & $\mathrm{sector}^{3}$ & $\mathrm{Sector}^{4}$ & $\begin{array}{c}\text { Sector } \\
5\end{array}$ & $8^{8 e c t o r}$ & Sector & Sectorl. & $\mathrm{Sector}^{9}$ & Sector & Sector & Sector \\
\hline Co-57 & 0.148 & 0.261 & 0.208 & 0.282 & 0.211 & 0.190 & 0.200 & 0.259 & 0.136 & 0.327 & 0.134 & 0.153 \\
\hline Co- 60 & 0.302 & 0.402 & 0.439 & 0.575 & 0.375 & 0.503 & 0.419 & 0.396 & 0.329 & 0.651 & 0.237 & 0.497 \\
\hline Sr-90 & 1.350 & 1.260 & 0.960 & 0.728 & 0.815 & 0.751 & 1.030 & 1.250 & 0.825 & 1.160 & 1.310 & 1.160 \\
\hline Sb-125 & 0.759 & 1.090 & 1.100 & 1.420 & 0.976 & 1.190 & 1.060 & 1.100 & 0.686 & 1.660 & 0.593 & 0.860 \\
\hline Cs-134 & 0.263 & 0.387 & 0.456 & 0.517 & 0.372 & 0.324 & 0.338 & 0.373 & 0.281 & 0.569 & 0.226 & 0.351 \\
\hline Cs-137 & 0.298 & 0.421 & 0.451 & 0.557 & 0.371 & 0.511 & 0.387 & 0.398 & 0.306 & 0.583 & 0.218 & 0.507 \\
\hline Eu-152 & 0.421 & 0.757 & 0.612 & 0.826 & 0.620 & 0.547 & 0.576 & 0.747 & 0.391 & 0.937 & 0.392 & 0.447 \\
\hline Eu-154 & 0.310 & 0.526 & 0.408 & 0.596 & 0.440 & 0.415 & 0.393 & 0.527 & 0.253 & 0.654 & 0.268 & 0.343 \\
\hline U-235 & 1.39 & 2.31 & 1.78 & 2.45 & 2.06 & 1.67 & 1.48 & 2.16 & 1.29 & 2.72 & 1.14 & 1.39 \\
\hline $\mathrm{U}-235^{\dagger}$ & 64.95 & 107.94 & 83.18 & 114.49 & 96.26 & 78.04 & 69.16 & 100.94 & 60.28 & 127.10 & 53.27 & 64.95 \\
\hline U-238 & 3.78 & 6.19 & 6.49 & 6.65 & 5.81 & 4.41 & 4.84 & 4.13 & 4.13 & 8.43 & 3.52 & 3.39 \\
\hline $\mathrm{U}-238^{\dagger}$ & 11.35 & 18.59 & 19.49 & 19.97 & 17.45 & 13.24 & 14.54 & 12.40 & 12.40 & 25.32 & 10.57 & 10.18 \\
\hline $\mathrm{Pu}-238$ & $0.99 *$ & 0.54 & 0.040 & 0.036 & 0.030 & $0.023^{*}$ & 0.059 & $0.043 *$ & 0.038 & $0.045^{*}$ & 0.053 & 0.051 \\
\hline Pu-239 & 0.033 & 0.012 & 0.028 & 0.019 & 0.018 & 0.018 & 0.001 & 0.024 & 0.007 & 0.008 & 0.024 & 0.008 \\
\hline Am-241 & 0.358 & 0.668 & 0.626 & 2.610 & 0.579 & 1.110 & 1.900 & 0.585 & 0.351 & 3.150 & 0.365 & 0.846 \\
\hline Nat-U & $0.269^{*}$ & $0.474^{*}$ & $0.054^{*}$ & $0.193^{*}$ & $0.052^{*}$ & $0.36^{*}$ & $0.627^{*}$ & $0.073^{*}$ & $0.187^{*}$ & $0.060^{*}$ & $0.391^{*}$ & $0.506^{*}$ \\
\hline Nat- $U^{\dagger}$ & 0.40 & 0.70 & 0.04 & 0.29 & 0.08 & 0.53 & 0.93 & 0.11 & 0.28 & 0.09 & 0.58 & 0.75 \\
\hline
\end{tabular}

(a) Locations are shown in Figure 7.

$+\mu \mathrm{g} / \mathrm{g}$ 
TABLE 10. SUMMARY OF RADIOLOGICAL ANALYSES OF FIELD CROPS WEST JEFFERSON SITE - 1994

$\mathrm{pCi} / \mathrm{g}$ dry weight ${ }^{(2)}$

All values are less than MDA values except where indicated (*)

\begin{tabular}{|c|c|c|c|c|c|c|c|c|c|c|c|c|}
\hline \multirow[b]{2}{*}{ Nuclide } & \multicolumn{12}{|c|}{ Identification No. ${ }^{6}$} \\
\hline & Sector 18 & Sector 2 & Sector 3 & Sector 4 & Sector 5 & Sector 6 & Sector 7 & Sector 8 & Sector 9 & Sector 10 & Sector 11 & Sector 12 \\
\hline $\mathrm{Co}-57$ & 0.070 & 0.086 & 0.060 & 0.097 & 0.059 & 0.071 & 0.069 & 0.093 & 0.058 & 0.098 & 0.060 & 0.073 \\
\hline Co-60 & 0.155 & 0.130 & 0.163 & 0.191 & 0.092 & 0.180 & 0.144 & 0.140 & 0.138 & 0.211 & 0.096 & 0.205 \\
\hline Sr-90 & 0.958 & 1.210 & 1.150 & 0.654 & 0.984 & 1.350 & 1.010 & 1.050 & $3.260 *$ & 1.060 & 0.764 & 0.891 \\
\hline $\mathrm{Sb}-125$ & 0.358 & 0.335 & 0.345 & 0.461 & 0.261 & 0.402 & 0.390 & 0.387 & 0.316 & 0.515 & 0.219 & 0.445 \\
\hline Cs- 134 & 0.134 & 0.127 & 0.120 & 0.158 & 0.104 & 0.165 & 0.112 & 0.123 & 0.125 & 0.165 & 0.091 & 0.146 \\
\hline Cs- 137 & 0.158 & 0.130 & 0.147 & 0.192 & 0.105 & 0.213 & 0.142 & 0.135 & 0.134 & 0.225 & 0.098 & 0.170 \\
\hline Eu-152 & 0.207 & 0.248 & 0.175 & 0.288 & 0.170 & 0.210 & 0.198 & 0.267 & 0.173 & 0.282 & 0.172 & 0.210 \\
\hline Eu-154 & 0.150 & 0.179 & 0.120 & 0.189 & 0.120 & 0.138 & 0.149 & 0.188 & 0.114 & 0.190 & 0.123 & 0.146 \\
\hline U-235 & 0.626 & 0.747 & 0.558 & 0.823 & 0.499 & 0.551 & 0.582 & 0.766 & 0.524 & 0.753 & 0.493 & 0.635 \\
\hline $\mathrm{U}-235^{\dagger}$ & 29.252 & 34.906 & 26.074 & 38.457 & 23.317 & 25.748 & 27.196 & 35.794 & 24.485 & 35.186 & 23.037 & 29.673 \\
\hline U-238 & 1.740 & 1.930 & 1.810 & 2.230 & 1.560 & 1.500 & 1.750 & 1.960 & 1.850 & 2.520 & 1.480 & 1.390 \\
\hline$U-238^{\dagger}$ & 5.225 & 5.796 & 5.435 & 6.697 & 4.685 & 4.505 & 5.255 & 5.886 & 5.556 & 7.568 & 4.444 & 4.174 \\
\hline Pu-238 & 0.049 & 0.043 & 0.053 & 0.031 & 0.037 & 0.048 & 0.038 & 0.047 & 0.023 & 0.052 & 0.036 & $0.039^{*}$ \\
\hline Pu-239 & 0.029 & 0.008 & 0.025 & 0.022 & 0.017 & 0.008 & 0.025 & 0.009 & 0.007 & 0.029 & 0.006 & 0.024 \\
\hline Am-241 & 0.167 & 0.210 & 0.171 & 0.958 & 0.157 & 0.385 & 0.162 & 0.211 & 0.148 & 0.943 & 0.153 & 0.405 \\
\hline Nat-U & 0.041 & 0.041 & 0.408 & 0.026 & $0.019^{*}$ & 0.004 & 0.003 & 0.004 & $0.006^{*}$ & 0.004 & 0.003 & 0.003 \\
\hline Nat- $\mathbf{U}^{\dagger}$ & 0.0606 & 0.0606 & 0.6027 & 0.0384 & $0.0281^{*}$ & 0.0059 & 0.0044 & 0.0059 & $0.0089 *$ & 0.0059 & 0.0044 & 0.0044 \\
\hline
\end{tabular}

(a) MDAs based on average sample volume of $48.13 \mathrm{~g}$.

(b) Locations are shown in Figure 7.

$\dagger \mu \mathrm{g} / \mathrm{g}$ 
TABLE 11. SUMMARY OF RADIOLOGICAL ANALYSES OF GARDEN CROPS ${ }^{\left({ }^{()}\right.}$ WEST JEFFERSON SITE - 1994

\begin{tabular}{|c|c|c|}
\hline \multirow[b]{2}{*}{ Nuclide } & \multicolumn{2}{|c|}{ pcilg dry weight } \\
\hline & On-Site & Off-Site ${ }^{(b)}$ \\
\hline Co-57 & $<0.071$ & $<0.112$ \\
\hline Co-60 & $<0.124$ & $<0.150$ \\
\hline Sr-90 & 0.110 & 0.110 \\
\hline Sb-125 & $<0.297$ & $<0.399$ \\
\hline Cs-134 & $<0.114$ & $<0.153$ \\
\hline Cs-137 & $<0.121$ & $<0.169$ \\
\hline Eu-152 & $<0.209$ & $<0.326$ \\
\hline Eu-154 & $<0.144$ & $<0.235$ \\
\hline U-235 & $<0.571$ & $<0.909$ \\
\hline $\mathrm{U}-235^{\dagger}$ & $<26.682$ & $<42.477$ \\
\hline U-238 & $<1.120$ & $<2.400$ \\
\hline $\mathrm{U} 238^{\dagger}$ & $<3.363$ & $<7.207$ \\
\hline Pu-238 & 0.026 & 0.039 \\
\hline Pu-239 & 0.210 & 0.009 \\
\hline Am-241 & $<0.183$ & $<0.272$ \\
\hline Nat-U & 0.175 & 0.078 \\
\hline Nat- $\mathrm{U}^{+}$ & 0.259 & 0.115 \\
\hline
\end{tabular}

(a) Garden crops collected at the end of the growing season.

(b) Locations are shown in Figure 7.

$+\mu \mathrm{g} / \mathrm{g}$ 


\section{TABLE 12. SUMMARY OF RADIOLOGICAL ANALYSES OF SEDIMENT SAMPLES ${ }^{(a)}$ \\ WEST JEFFERSON SITE - 1994}

\begin{tabular}{|c|c|c|c|c|c|}
\hline \multirow[b]{2}{*}{ Nuclide } & \multicolumn{5}{|c|}{ pCi/g dry wt. ${ }^{(6)}$ Avg. } \\
\hline & ED - 1 & ED-2 & ED-3 & $E D-4$ & ED - 5 \\
\hline Co-57 & $<0.078$ & $<0.058$ & $<0.060$ & $<0.072$ & $<0.058$ \\
\hline Co-60 & $<6.980$ & $<0.152$ & $<0.103$ & $<0.143$ & $<0.092$ \\
\hline Sr-90 & 8.550 & 0.590 & 0.621 & 0.600 & 0.595 \\
\hline $\mathrm{Sb}-125$ & $<0.436$ & $<0.327$ & $<0.253$ & $<0.319$ & $<0.208$ \\
\hline Cs-134 & $<0.156$ & $<0.119$ & $<0.092$ & $<0.111$ & $<0.082$ \\
\hline Cs-137 & 6.370 & 0.338 & 0.237 & 0.470 & $<0.098$ \\
\hline $\mathrm{Eu}-152$ & $<0.292$ & $<0.231$ & $<0.175$ & $<0.251$ & $<0.172$ \\
\hline $\mathrm{Eu}-154$ & $<0.208$ & $<0.163$ & $<0.126$ & $<0.184$ & $<0.121$ \\
\hline U-235 & $<0.513$ & $<0.365$ & $<0.321$ & $<0.475$ & $<0.300$ \\
\hline $\mathrm{U}-235^{\dagger}$ & $<23.972$ & $<17.056$ & $<15.000$ & $<22.196$ & $<14.019$ \\
\hline U-238 & $<2.860$ & $<1.550$ & 1.800 & $<1.580$ & $<1.450$ \\
\hline $\mathrm{U}-238^{\dagger}$ & $<8.589$ & $<4.655$ & 5.405 & $<4.745$ & $<4.354$ \\
\hline $\mathrm{Pu}-238^{(\mathrm{c})}$ & 0.359 & 0.223 & 0.153 & $<0.194$ & 0.207 \\
\hline $\mathrm{Pu}-239^{(\mathrm{c})}$ & $<0.015$ & $<0.012$ & 0.020 & $<0.025$ & 0.040 \\
\hline Am-241 & $<9.630$ & $<0.216$ & $<0.146$ & $<0.247$ & $<0.136$ \\
\hline Nat-U $U^{(\mathbf{c})}$ & 2.290 & 1.600 & 1.38 & 1.240 & 1.320 \\
\hline Nat- $U^{\dagger}$ & 3.383 & 2.363 & 2.038 & 1.832 & 1.950 \\
\hline
\end{tabular}

(a) Locations are shown in Figure 6.

(b) No standards for radionuclides in sediment have been established.

(c) Annual sample only.

$\dagger \mu g / g$ 
TABLE 13. SUMMARY OF SOIL ANALYSES-WEST JEFFERSON SITE-1994

pCi/g dry weight

All values are less than MDA values except where indicated (*)

\begin{tabular}{|c|c|c|c|c|c|c|c|c|c|c|c|c|}
\hline \multirow[b]{2}{*}{ Nuclide } & \multicolumn{12}{|c|}{ Identification No 6} \\
\hline & Sector & Sector & Sector & Sector & Sector & soctor & Sector? & Sector & sector & Sector & sector 11 . & Sector 12 \\
\hline Co-57 & 0.102 & 0.106 & 0.091 & 0.137 & 0.087 & 0.122 & 0.102 & 0.100 & 0.092 & 0.158 & 0.099 & 0.115 \\
\hline Co-60 & 0.232 & 0.143 & 0.207 & 0.256 & 0.148 & 0.271 & 0.226 & 0.137 & 0.277 & 0.243 & 0.153 & 0.291 \\
\hline Sr-90 & 0.899 & $1.640^{*}$ & 1.14 & 0.940 & 1.030 & $2.040^{*}$ & 1.060 & 0.963 & $3.350^{*}$ & 0.956 & 0.914 & 1.090 \\
\hline $\mathrm{Sb}-125$ & 0.500 & 0.406 & 0.393 & 0.596 & 0.343 & 0.660 & 0.426 & 0.430 & 0.421 & 0.686 & 0.381 & 0.777 \\
\hline Cs-134 & 0.170 & 0.143 & 0.174 & 0.265 & 0.128 & 0.215 & 0.213 & 0.138 & 0.175 & 0.233 & 0.125 & 0.238 \\
\hline Cs-137 & $0.981^{*}$ & 0.199 & 0.405 & 0.312 & 1.070 & 0.601 & 0.833 & 0.452 & $0.821^{*}$ & $0.867^{*}$ & $0.466^{*}$ & $0.761^{*}$ \\
\hline Eu-152 & 0.302 & 0.308 & 0.252 & 0.395 & 0.252 & 0.350 & 0.299 & 0.287 & 0.277 & 0.456 & 0.285 & 0.338 \\
\hline Eu-154 & 0.201 & 0.215 & 0.189 & 0.282 & 0.188 & 0.246 & 0.204 & 0.216 & 0.184 & 0.336 & 0.194 & 0.201 \\
\hline U-235 & 0.866 & 0.927 & 0.794 & 1.020 & 0.751 & 0.980 & $0.849^{*}$ & 0.859 & 0.819 & 1.160 & 0.829 & 0.865 \\
\hline$U-235^{\dagger}$ & 40.467 & 43.318 & 37.103 & 47.664 & 35.093 & 45.794 & $39.673^{*}$ & 40.140 & 38.271 & 54.206 & 34.542 & 40.421 \\
\hline U-238 & 1.850 & 0.253 & 2.540 & 3.460 & 2.100 & 2.550 & 1.860 & 2.320 & 2.520 & 3.870 & 2.360 & 2.840 \\
\hline $\mathrm{U}-238^{\dagger}$ & 5.556 & 0.760 & 7.628 & 10.390 & 6.306 & 7.658 & 5.586 & 6.967 & 7.568 & 11.622 & 7.087 & 8.529 \\
\hline Pu-238 & $0.128 *$ & $0.407^{*}$ & $0.205^{*}$ & $0.207^{*}$ & $0.109 *$ & $0.318^{*}$ & $0.202^{*}$ & $0.171^{*}$ & 0.054 & $0.148^{*}$ & $0.169^{*}$ & $0.216^{*}$ \\
\hline Pu-239 & $0.018^{*}$ & 0.026 & 0.011 & 0.017 & 0.050 & 0.040 & 0.011 & 0.051 & 0.021 & 0.035 & 0.043 & 0.038 \\
\hline Am-241 & 0.247 & 0.268 & 0.260 & 1.160 & 0.226 & 0.648 & 0.280 & 0.281 & 0.258 & 1.290 & 0.262 & 0.791 \\
\hline Nat-U & $2.240^{*}$ & $2.040^{*}$ & $1.840 *$ & $2.020 *$ & $1.830^{*}$ & $2.150^{*}$ & $2.230^{*}$ & $2.200^{*}$ & $2.400^{*}$ & $2.070^{*}$ & $2.300^{*}$ & $2.810^{*}$ \\
\hline Nat-U $U^{+}$ & $4.298^{*}$ & $3.013^{*}$ & $2.718^{*}$ & $5.761^{*}$ & $2.703^{*}$ & $3.176^{*}$ & $3.294^{*}$ & $3.250^{*}$ & $3.545^{*}$ & $3.058^{*}$ & $3.397^{*}$ & $4.151^{*}$ \\
\hline
\end{tabular}

(a) Locations are shown in Figure 7.

$+\mu \mathrm{g} / \mathrm{g}$ 


\section{TABLE 14. SUMMARY OF FISH TISSUE ANALYSES WEST JEFFERSON SITE - 1994}

\begin{tabular}{|c|c|c|c|c|c|c|}
\hline \multirow[b]{2}{*}{ Nuclide } & \multicolumn{3}{|c|}{$\begin{array}{l}\text { Battelle Lake Samples } \\
\text { (pCl/g raw weight) }\end{array}$} & \multicolumn{3}{|c|}{$\begin{array}{l}\text { Darby Creek Samples } \\
(\text { pCi/g raw weight) }\end{array}$} \\
\hline & 1st Half & 2nd Half & Average & 1st Half & 2nd Half & Average \\
\hline $\mathrm{Co}-57$ & $<0.090$ & $<0.083$ & $<0.087$ & $\mathrm{NC}$ & $<0.102$ & $<0.102$ \\
\hline 80.60 & $<0.099$ & $<0.194$ & $<0.147$ & $\mathrm{NC}$ & $<0.207$ & $<0.207$ \\
\hline Sr 90 & $<1.180$ & $<1.470$ & $<1.330$ & $\mathrm{NC}$ & $<0.984$ & $<0.984$ \\
\hline $56-125$ & $<0.273$ & $<0.436$ & $<0.354$ & $\mathrm{NC}$ & $<0.374$ & $<0.374$ \\
\hline $\operatorname{ses} 134$ & $<0.099$ & $<0.166$ & $<0.132$ & $\mathrm{NC}$ & $<0.146$ & $<0.146$ \\
\hline Cs. 137 & $<0.096$ & $<0.162$ & $<0.129$ & $\mathrm{NC}$ & $<0.163$ & $<0.163$ \\
\hline 10152 & $<0.160$ & $<0.214$ & $<0.187$ & $\mathrm{NC}$ & $<0.235$ & $<0.235$ \\
\hline Eut 154 & $<0.119$ & $<0.156$ & $<0.137$ & $\mathrm{NC}$ & $<0.156$ & $<0.156$ \\
\hline 4235 & $<0.479$ & $<0.604$ & $<0.542$ & $\mathrm{NC}$ & $<0.597$ & $<0.597$ \\
\hline 10235 & $<22.383$ & $<29.224$ & $<25.327$ & $\mathrm{NC}$ & $<27.90$ & $<27.90$ \\
\hline 10238 & $<1.440$ & $<1.400$ & $<1.420$ & $\mathrm{NC}$ & $<1.940$ & $<1.940$ \\
\hline 14238 & $<4.324$ & $<4.204$ & $<4.264$ & $\mathrm{NC}$ & $<5.826$ & $<5.826$ \\
\hline $\mathrm{Pu} 238$ & $<0.017$ & $<0.013$ & $<0.015$ & $\mathrm{NC}$ & $<0.012$ & $<0.012$ \\
\hline$P \cup-239$ & $<0.013$ & $<0.011$ & $<0.012$ & $\mathrm{NC}$ & $<0.004$ & $<0.004$ \\
\hline $4 m-24$ & $<0.146$ & $<0.418$ & $<0.282$ & $\mathrm{NC}$ & $<0.679$ & $<0.679$ \\
\hline Wat-18 & $<0.041$ & $<0.004$ & $<0.022$ & $\mathrm{NC}$ & $<0.408$ & $<0.408$ \\
\hline Nat- It & $<0.061$ & $<0.006$ & $<0.033$ & $\mathrm{NC}$ & $<0.603$ & $<0.603$ \\
\hline
\end{tabular}

(a) Fish samples were collected from various locations within Battelle Lake.

NC Denotes fish not collected due to poor collection conditions.

$\dagger \mu \mathrm{g} / \mathrm{g}$ 


\section{TABLE 15. INTEGRATED EXTERNAL BACKGROUND RADIATION MEASUREMENTS AT RECREATION AREA AND PROPERTY BOUNDARY LINE WEST JEFFERSON SITE - 1994}

\begin{tabular}{|c|c|c|c|c|c|}
\hline \multirow{2}{*}{$\begin{array}{l}\text { Pocation and } \\
\text { Distance }\end{array}$} & \multicolumn{4}{|c|}{ Integrated TLD Measurements in rem } & \multirow{2}{*}{$\begin{array}{l}\text { Total for } \\
\text { rear }\end{array}$} \\
\hline & ist Otr. & $2 \mathrm{nd}$ Qtr. & 3 rd Otr: & 4th Or. & \\
\hline $\begin{array}{l}\text { Southwest } \\
121.9 \mathrm{~m}(400 \mathrm{ft}) \\
420.6 \mathrm{~m}(600 \mathrm{ft}) \\
731.5 \mathrm{~m}(2400 \mathrm{ft}) \\
1234.5 \mathrm{~m}(4050 \mathrm{ft})\end{array}$ & $\begin{array}{l}<0.030 \\
<0.030 \\
<0.030 \\
<0.030\end{array}$ & $\begin{array}{l}<0.030 \\
<0.030 \\
<0.030 \\
<0.030\end{array}$ & $\begin{array}{l}<0.030 \\
<0.030 \\
<0.030 \\
<0.030\end{array}$ & $\begin{array}{l}<0.030 \\
<0.030 \\
<0.030 \\
<0.030\end{array}$ & $\begin{array}{l}<0.120 \\
<0.120 \\
<0.120 \\
<0.120\end{array}$ \\
\hline $\begin{array}{l}\text { West } \\
152.4 \mathrm{~m}(500 \mathrm{ft}) \\
630.9 \mathrm{~m}(2070 \mathrm{ft})\end{array}$ & $\begin{array}{l}<0.030 \\
<0.030\end{array}$ & $\begin{array}{l}<0.030 \\
<0.030\end{array}$ & $\begin{array}{l}<0.030 \\
<0.030\end{array}$ & $\begin{array}{l}<0.030 \\
<0.030\end{array}$ & $\begin{array}{l}<0.120 \\
<0.120\end{array}$ \\
\hline $\begin{array}{l}\text { Southeast } \\
365.8 \mathrm{~m}(1200 \mathrm{ft}) \\
1005.9 \mathrm{~m}(3300 \mathrm{ft})\end{array}$ & $\begin{array}{l}<0.030 \\
<0.030 \\
\end{array}$ & $\begin{array}{l}<0.030 \\
<0.030\end{array}$ & $\begin{array}{l}<0.030 \\
<0.030\end{array}$ & $\begin{array}{l}<0.030 \\
<0.030\end{array}$ & $\begin{array}{l}<0.120 \\
<0.120\end{array}$ \\
\hline $\begin{array}{l}\text { South } \\
395.9 \mathrm{~m}(1200 \mathrm{ft}) \\
411.5 \mathrm{~m}(1350 \mathrm{ft}) \\
548.6 \mathrm{~m}(1800 \mathrm{ft}) \\
1097.3 \mathrm{~m}(3600 \mathrm{ft})\end{array}$ & $\begin{array}{l}<0.030 \\
<0.030 \\
<0.030 \\
<0.030\end{array}$ & $\begin{array}{l}<0.030 \\
<0.030 \\
<0.030 \\
<0.030\end{array}$ & $\begin{array}{l}<0.030 \\
<0.030 \\
<0.030 \\
<0.030\end{array}$ & $\begin{array}{l}<0.030 \\
<0.030 \\
<0.030 \\
<0.030\end{array}$ & $\begin{array}{l}<0.120 \\
<0.120 \\
<0.120 \\
<0.120\end{array}$ \\
\hline $\begin{array}{l}\text { East } \\
420.6 \mathrm{~m}(1380 \mathrm{ft})\end{array}$ & $\leq 0.030$ & $<0.030$ & $<0.030$ & $\leq 0.030$ & $<0.120$ \\
\hline $\begin{array}{l}\text { Northeast } \\
395.9 \mathrm{~m}(1200 \mathrm{ft})\end{array}$ & $\leq 0.030$ & $<0.030$ & $<0.030$ & $<0.030$ & $<0.120$ \\
\hline $\begin{array}{l}\text { Northwest } \\
402.3 \mathrm{~m}(1320 \mathrm{ft})\end{array}$ & $<0.030$ & $<0.030$ & $<0.030$ & $\leq 0.030$ & $<0.120$ \\
\hline $\begin{array}{l}\text { North } \\
457.2 \mathrm{~m}(1500 \mathrm{ft})\end{array}$ & $<0.030$ & $<0.030$ & $<0.030$ & $<0.030$ & $<0.120$ \\
\hline
\end{tabular}

(a) Refer to Figure 8. Average off-site background for year $<0.120 \mathrm{rem}$. 
TABLE 16. SUMMARY OF SITE BOUNDARY AIR SAMPLE ANALYSES KING AVENUE SITE - 1994

\begin{tabular}{|c|c|c|c|c|}
\hline Ninclide: & 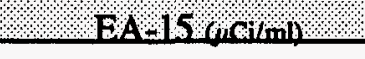 & 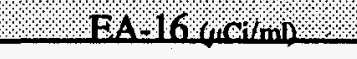 & 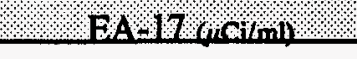 & 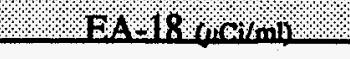 \\
\hline Gross Alpha & $1.67 \mathrm{E}-15+6.18 \mathrm{E}-16$ & $1.62 \mathrm{E}-15 \pm 5.96 \mathrm{E}-16$ & $1.71 \mathrm{E}-15 \pm 6.14 \mathrm{E}-16$ & $1.79 \mathrm{E}-15 \pm 6.28 \mathrm{E}-16$ \\
\hline Gross Beta & $1.47 \mathrm{E}-14 \pm 1.25 \mathrm{E}-15$ & $1.47 \mathrm{E}-14 \pm 1.23 \mathrm{E}-15$ & $1.48 \mathrm{E}-14 \pm 1.25 \mathrm{E}-15$ & $1.54 \mathrm{E}-14 \pm 1.27 \mathrm{E}-15$ \\
\hline $\mathrm{C} 0-57$ & $3.43 \mathrm{E}-16$ & $4.26 \mathrm{E}-16$ & 3.77E-16 & 4.47E-16 \\
\hline $\mathrm{Co}-60$ & $6.49 \mathrm{E}-16$ & $8.54 \mathrm{E}-16$ & $7.19 \mathrm{E}-16$ & $7.96 \mathrm{E}-16$ \\
\hline $\mathrm{Sb}-125$ & $1.49 \mathrm{E}-15$ & $1.67 \mathrm{E}-15$ & $1.45 \mathrm{E}-15$ & $1.94 \mathrm{E}-15$ \\
\hline Cs-134 & $5.58 \mathrm{E}-16$ & $5.83 \mathrm{E}-16$ & $5.84 \mathrm{E}-16$ & $6.15 \mathrm{E}-16$ \\
\hline Cs-137 & $6.39 \mathrm{E}-16$ & $7.11 \mathrm{E}-16$ & $5.93 \mathrm{E}-16$ & $5.93 \mathrm{E}-16$ \\
\hline $\mathrm{Eu}-152$ & 8.28E-16 & $1.01 \mathrm{E}-15$ & $9.13 \mathrm{E}-16$ & $1.04 \mathrm{E}-15$ \\
\hline Eu-154 & $5.84 \mathrm{E}-16$ & $7.10 \mathrm{E}-16$ & $6.30 \mathrm{E}-16$ & $7.42 \mathrm{E}-16$ \\
\hline $\mathrm{U}-235$ & $2.45 \mathrm{E}-15$ & 3.07E-15 & $2.63 \mathrm{E}-15$ & $3.18 \mathrm{E}-15$ \\
\hline $\mathrm{U}-235(\mathrm{pg} / \mathrm{ml})$ & 0.114 & 0.143 & 0.123 & 0.149 \\
\hline $\mathrm{U}-238$ & $5.37 \mathrm{E}-15$ & $5.28 \mathrm{E}-15$ & $5.53 \mathrm{E}-15$ & $6.50 \mathrm{E}-15$ \\
\hline $\mathrm{U}-238(\mathrm{pg} / \mathrm{ml})$ & 0.016 & 0.016 & 0.017 & 0.020 \\
\hline Th-228 & $4.61 \mathrm{E}-14$ & $6.09 \mathrm{E}-14$ & $5.68 \mathrm{E}-14$ & $5.81 \mathrm{E}-14$ \\
\hline Th-230 & $1.70 \mathrm{E}-13$ & $2.36 \mathrm{E}-13$ & $1.35 \mathrm{E}-13$ & $1.83 \mathrm{E}-13$ \\
\hline Th-232 & 3.97E-14 & $5.27 \mathrm{E}-14$ & 4.17E-14 & $6.60 \mathrm{E}-14$ \\
\hline Am-241 & $3.79 \mathrm{E}-16$ & $1.33 \mathrm{E}-15$ & $8.50 \mathrm{E}-16$ & $8.17 \mathrm{E}-16$ \\
\hline Nat-U & $5.06 \mathrm{E}-14$ & $1.33 \mathrm{E}-15$ & $8.50 \mathrm{E}-16$ & $8.17 \mathrm{E}-16$ \\
\hline Nat-U (pg/ml) & 0.075 & 0.081 & 0.077 & 0.086 \\
\hline
\end{tabular}

(a) Locations are shown in Figure 4.

(b) All isotopic values represent average MDL values (a posteriori). U-235, U-238, and Am-241 associated $\gamma$ produce higher MDL values than gross $\alpha$ and $\beta$ results would indicate. Gross $\alpha \mathrm{MDL}$ is $3.0 \times 10^{-16} \mu \mathrm{Ci} / \mathrm{ml}$ and gross $\beta \mathrm{MDL}$ is $6.0 \times 10^{-16} \mu \mathrm{Ci} / \mathrm{ml}$ (a priori).

(c) Detection limit is 4.66 multiplied by the standard deviation of the background, divided by the efficiency, assuming a 50 percent recovery of the spike, and a flow volume of $2.7 \mathrm{E}+9 \mathrm{ml}$. 
TABLE 17. RADIOLOGICAL ANALYSES OF LIQUID DISCHARGES-KING AVENUE SITE -1994

$\mu \mathrm{Ci} / \mathrm{ml}$

All values reported are less than MDA values unless otherwise indicated *

\begin{tabular}{|c|c|c|c|c|c|c|c|c|c|}
\hline \multirow[b]{2}{*}{ Nuclide } & \multicolumn{9}{|c|}{ Identification No 9} \\
\hline & EW 6 . & $\mathrm{Ew} 7$ & EW -8. & EW.9. & EW 13 & EW 14 & Average & $\mathrm{DCG} / \mu \mathrm{Cj} / \mathrm{ml}$ & $\%$ DCG \\
\hline $\begin{array}{l}\text { Gross } \alpha \\
\left(\mu \mathrm{Ci} / \mathrm{ml} \times 10^{-5}\right)\end{array}$ & $5.81 \pm 2.80$ & $15.95 \pm 5.59$ & $5.14 \pm 2.36$ & $9.35 \pm 3.20$ & $17.71 \pm 10.20$ & $10.23 \pm 3.59$ & & & \\
\hline $\begin{array}{l}\text { Gross } \beta \\
\left(\mu \mathrm{Ci} / \mathrm{ml} \times 10^{-6}\right)\end{array}$ & $14.90 \pm 1.41$ & $26.22 \pm 1.86$ & $17.09 \pm 1.45$ & $18.05 \pm 1.51$ & $37.26 \pm 4.11$ & $35.33 \pm 2.01$ & & & \\
\hline $\mathrm{Co}-57$ & $<2.05 \mathrm{E}-09$ & $<2.23 \mathrm{E}-09$ & $<1.99 \mathrm{E}-09$ & $<2.44 \mathrm{E}-09$ & $<2.04 \mathrm{E}-09$ & $<2.07 \mathrm{E}-09$ & $2.14 \mathrm{E}-09$ & $1.0 \mathrm{E}-04$ & 0.00 \\
\hline Co-60 & $<2.28 \mathrm{E}-09$ & $<2.02 \mathrm{E}-09$ & $<2.25 \mathrm{E}-09$ & $<3.38 \mathrm{E}-09$ & $<2.28 \mathrm{E}-09$ & $<3.12 \mathrm{E}-09$ & $2.56 \mathrm{E}-09$ & $5.0 \mathrm{E}-06$ & 0.05 \\
\hline $\mathrm{Sb}-125$ & $<6.38 \mathrm{E}-09$ & $<6.03 \mathrm{E}-09$ & $<6.34 \mathrm{E}-09$ & $<8.74 \mathrm{E}-09$ & $<6.35 \mathrm{E}-09$ & $<7.72 \mathrm{E}-09$ & $6.93 \mathrm{E}-09$ & $5.0 \mathrm{E}-05$ & 0.01 \\
\hline Cs-134 & $<2.22 \mathrm{E}-09$ & $<2.09 \mathrm{E}-09$ & $<2.28 \mathrm{E}-09$ & $<3.10 \mathrm{E}-09$ & $<2.22 \mathrm{E}-09$ & $<2.74 \mathrm{E}-09$ & $2.44 \mathrm{E}-09$ & $2.0 \mathrm{E}-06$ & 0.12 \\
\hline Cs-137 & $<2.46 \mathrm{E}-09$ & $<5.54 \mathrm{E}-09$ & $<2.43 \mathrm{E}-09$ & $<3.31 \mathrm{E}-09$ & $<2.87 \mathrm{E}-09$ & $<3.00 \mathrm{E}-09$ & $2.71 \mathrm{E}-09$ & $3.0 \mathrm{E}-06$ & 0.09 \\
\hline Eu-152 & $<5.42 \mathrm{E}-09$ & $<5.21 \mathrm{E}-09$ & $<5.61 \mathrm{E}-09$ & $<6.64 \mathrm{E}-09$ & $<5.34 \mathrm{E}-09$ & $<5.87 \mathrm{E}-09$ & $5.74 \mathrm{E}-09$ & $2.0 \mathrm{E}-05$ & 0.03 \\
\hline Eu-154 & $<3.81 \mathrm{E}-09$ & $<3.90 \mathrm{E}-09$ & $<3.91 \mathrm{E}-09$ & $<4.66 \mathrm{E}-09$ & $<3.73 \mathrm{E}-09$ & $<4.12 \mathrm{E}-09$ & $4.02 \mathrm{E}-09$ & $2.0 \mathrm{E}-05$ & 0.02 \\
\hline Am-241 & $<6.27 \mathrm{E}-09$ & $<7.45 \mathrm{E}-09$ & $<6.47 \mathrm{E}-09$ & $<1.28 \mathrm{E}-08$ & $<7.15 \mathrm{E}-09$ & $<9.58 \mathrm{E}-09$ & $8.29 \mathrm{E}-09$ & $3.0 \mathrm{E}-08$ & 27.62 \\
\hline U-235 & $<1.21 \mathrm{E}-08$ & $<9.55 \mathrm{E}-09$ & $<1.32 \mathrm{E}-08$ & $<1.49 \mathrm{E}-09$ & $<1.11 \mathrm{E}-08$ & $<1.45 \mathrm{E}-08$ & $1.26 \mathrm{E}-08$ & $6.0 \mathrm{E}-07$ & 2.09 \\
\hline U-235 & $<5.65 \mathrm{E}-01$ & $<4.46 \mathrm{E}-01$ & $<6.17 \mathrm{E}-01$ & $<6.96 \mathrm{E}-01$ & $<5.19 \mathrm{E}-01$ & $<6.78 \mathrm{E}-01$ & $5.89 \mathrm{E}-01$ & $2.8 \mathrm{E}+01$ & \\
\hline U-238 & $<8.36 \mathrm{E}-08$ & $<7.15 \mathrm{E}-08$ & $<3.96 \mathrm{E}-08$ & $<7.13 E-08$ & $<4.24 \mathrm{E}-08$ & $<5.80 \mathrm{E}-08$ & $6.11 \mathrm{E}-08$ & $6.0 \mathrm{E}-07$ & 10.18 \\
\hline $\mathrm{U}-238^{\dagger}$ & $<2.51 \mathrm{E}-01$ & $<2.15 \mathrm{E}-01$ & $<1.19 \mathrm{E}-01$ & $<2.14 \mathrm{E}-01$ & $<1.27 \mathrm{E}-01$ & $<1.74 \mathrm{E}-01$ & $1.84 \mathrm{E}-01$ & $1.8 \mathrm{E}+00$ & \\
\hline U-Nat & $1.16 \mathrm{E}-10^{*}$ & $5.65 \mathrm{E}-09 *$ & $<2.72 \mathrm{E}-12$ & $<2.72 \mathrm{E}-12$ & $3.22 \mathrm{E}-09 *$ & $<2.72 \mathrm{E}-12$ & $1.50 \mathrm{E}-09$ & $6.0 \mathrm{E}-07$ & 0.25 \\
\hline U-Nat ${ }^{\dagger}$ & $1.71 \mathrm{E}-04^{*}$ & $8.35 \mathrm{E}-03^{*}$ & $<4.02 \mathrm{E}-06$ & $<4.02 \mathrm{E}-06$ & $<4.76 \mathrm{E}-03^{*}$ & $<4.02 \mathrm{E}-06$ & $2.22 \mathrm{E}-03$ & $8.9 E+01$ & \\
\hline Th-228 & $<5.86 \mathrm{E}-10$ & $<5.67 \mathrm{E}-10$ & $<5.82 \mathrm{E}-10$ & $<5.28 \mathrm{E}-10$ & $<5.54 \mathrm{E}-10$ & $<7.06 \mathrm{E}-10$ & $5.96 \mathrm{E}-10$ & $4.0 \mathrm{E}-07$ & 0.15 \\
\hline Th-230 & $<6.20 \mathrm{E}-10$ & $<5.41 \mathrm{E}-10$ & $7.25 \mathrm{E}-10^{*}$ & $<4.92 \mathrm{E}-10$ & $5.29 \mathrm{E}-10^{*}$ & $7.23 \mathrm{E}-10^{*}$ & $6.05 \mathrm{E}-10$ & 3.0E-07 & 0.20 \\
\hline Th-232 & $<4.66 \mathrm{E}-10$ & $<5.11 \mathrm{E}-10$ & $<5.54 \mathrm{E}-10$ & $<4.32 \mathrm{E}-10$ & $<3.62 \mathrm{E}-10$ & $<5.36 \mathrm{E}-10$ & 4.77E-10 & $5.0 \mathrm{E}-08$ & 0.95 \\
\hline
\end{tabular}

(a) Locations identified in Figure 4.

$+\mu \mathrm{g} / \mathrm{ml}$ 
TABLE 18. RADIOLOGICAL ANALYSES OF SOIL SAMPLES - KING AVENUE SITE - 1994

$\mathrm{pCi} / \mathrm{g}$ dry weight

All values are less than MDA values except where indicated $(*)$

\begin{tabular}{|c|c|c|c|c|c|c|c|c|c|}
\hline \multirow[b]{2}{*}{ Nuclids } & \multicolumn{9}{|c|}{ Identification No. } \\
\hline & KAES-01 & $\mathrm{KAES}-02$ & KAES 03 & KAES - 04 & KAES 05 & KAES 06 & KAES 07 & KAES .08 & KAES 09 \\
\hline Co-57 & 0.074 & 0.057 & 0.063 & 0.065 & 0.053 & 0.063 & 0.053 & 0.063 & 0.048 \\
\hline Co-60 & 0.097 & 0.109 & 0.120 & 0.103 & 0.093 & 0.105 & 0.113 & 0.084 & 0.088 \\
\hline $\mathrm{Sb}-125$ & 0.290 & 0.280 & 0.257 & 0.212 & 0.236 & 0.257 & 0.273 & 0.212 & 0.198 \\
\hline Cs-134 & 0.096 & 0.081 & 0.076 & 0.066 & 0.081 & 0.090 & 0.085 & 0.083 & 0.074 \\
\hline Cs-137 & $0.974 *$ & $0.892^{*}$ & $0.552^{*}$ & $0.220^{*}$ & $0.185^{*}$ & $0.647^{*}$ & $0.694^{*}$ & $0.678 *$ & $0.228 *$ \\
\hline Eu-152 & 0.214 & 0.165 & 0.184 & 0.188 & 0.155 & 0.182 & 0.153 & 0.185 & 0.140 \\
\hline Eu-154 & 0.144 & 0.115 & 0.132 & 0.128 & 0.105 & 0.130 & 0.116 & 0.123 & 0.101 \\
\hline $\mathrm{U}-235$ & $0.616^{*}$ & 0.498 & $0.502 *$ & 0.501 & 0.408 & 0.558 & $0.457^{*}$ & 0.546 & 0.435 \\
\hline $\mathrm{U}-235^{\dagger}$ & $28.785 *$ & 23.271 & $23.458 *$ & 23.411 & 19.065 & 26.074 & $21.355^{*}$ & 25.514 & 20.327 \\
\hline U-238 & 1.750 & 1.290 & 1.560 & 1.360 & 0.894 & 1.29 & 1.22 & 1.58 & $3.62 *$ \\
\hline $\mathrm{U}-238^{\dagger}$ & 5.255 & 3.874 & 4.685 & 4.084 & 2.685 & 3.874 & 3.664 & 4.745 & $10.876^{*}$ \\
\hline Th-228 & $0.892^{*}$ & $1.130^{*}$ & $0.990^{*}$ & $1.050^{*}$ & $1.040^{*}$ & $1.030^{*}$ & $1.150 *$ & $0.943^{*}$ & $1.100^{*}$ \\
\hline Th-230 & $2.360^{*}$ & $3.220 *$ & $2.410^{*}$ & $2.630^{*}$ & $2.690^{*}$ & $2.390 *$ & $2.760^{*}$ & $2.510^{*}$ & $2.480^{*}$ \\
\hline Th-232 & $1.010 *$ & $1.110^{*}$ & $1.050^{*}$ & $1.070^{*}$ & $1.060^{*}$ & 1.120 & $1.170^{*}$ & $0.996 *$ & $1.030^{*}$ \\
\hline Am-241 & 0.630 & 0.373 & 0.591 & 0.611 & 0.321 & 0.619 & 0.370 & 0.580 & 0.293 \\
\hline Nat-U & 2.770 & $4.900 *$ & $2.370^{*}$ & $3.070^{*}$ & $2.720^{*}$ & $2.280^{*}$ & $3.140^{*}$ & $2.680^{*}$ & $2.540^{*}$ \\
\hline Nat-U $\mathbf{U}^{\dagger}$ & 4.092 & $7.238^{*}$ & $3.501^{*}$ & $4.535 *$ & $4.018^{*}$ & $3.368^{*}$ & $4.638^{*}$ & $3.959 *$ & $3.752 *$ \\
\hline
\end{tabular}

(a) Locations are identified in Figure 4, except KAES-09, which is an off-site sample taken from The Ohio State University Agriculture campus. 
TABLE 19. RADIOLOGICAL ANALYSES OF VEGETATION SAMPLES-KING AVENUE SITE-1994

pCi/g dry weight

All values are less than MDA values except where indicated (*)

\begin{tabular}{|c|c|c|c|c|c|c|c|c|c|}
\hline \multirow[b]{2}{*}{ Nuclide } & \multicolumn{9}{|c|}{ Lentification No. } \\
\hline & KAEV 01 & KAEV - 02 & KAEV 03 & KAEV 04 & KAEV 05 & KAEV 06 : & KAEV 07 ? & KAEV 08 & KAEV 09 \\
\hline $\mathrm{Co}-57$ & 0.143 & 0.129 & 0.296 & 0.182 & 0.133 & 0.263 & 0.263 & 0.130 & 0.167 \\
\hline $\mathrm{Co}-60$ & 0.223 & 0.253 & 0.602 & 0.344 & 0.315 & 0.404 & 0.529 & 0.387 & 0.402 \\
\hline $\mathrm{Sb}-125$ & 0.563 & 0.602 & 1.440 & 0.861 & 0.590 & 1.090 & 1.110 & 0.759 & 0.855 \\
\hline Cs-134 & 0.240 & 0.207 & 0.586 & 0.303 & 0.264 & 0.373 & 0.454 & 0.302 & 0.407 \\
\hline Cs-137 & 0.252 & $0.757^{*}$ & 0.617 & 0.374 & 0.264 & 0.415 & 0.452 & 0.352 & 0.419 \\
\hline Eu-152 & 0.418 & 0.380 & 0.865 & 0.535 & 0.390 & 0.770 & 0.770 & 0.367 & 0.497 \\
\hline Eu-154 & 0.302 & 0.269 & 0.596 & 0.380 & 0.270 & 0.551 & 0.568 & 0.276 & 0.352 \\
\hline U-235 & 1.230 & 1.070 & 2.730 & 1.540 & 1.110 & 2.130 & 1.940 & 1.020 & 1.560 \\
\hline $\mathrm{U}-235^{\dagger}$ & 57.477 & 50.000 & 127.570 & 71.963 & 51.869 & 99.533 & 90.654 & 47.664 & .72 .897 \\
\hline U-238 & 3.600 & 3.250 & 7.710 & 4.650 & 3.820 & 5.920 & 5.700 & 2.760 & 5.300 \\
\hline U-238 & 10.811 & 9.760 & 23.153 & 13.964 & 11.41 & 17.778 & 17.117 & 8.288 & 15.916 \\
\hline Th-228 & $0.097^{*}$ & $0.479 *$ & $0.166^{*}$ & $0.045^{*}$ & $0.070 *$ & $0.097 *$ & $0.098 *$ & $0.242^{*}$ & 0.041 \\
\hline Th-230 & $0.258 *$ & $1.470^{*}$ & $0.133^{*}$ & $0.108^{*}$ & $0.176^{*}$ & $0.201^{*}$ & $0.229^{*}$ & $0.670^{*}$ & $0.092^{*}$ \\
\hline Th-232 & $0.091^{*}$ & $0.450^{*}$ & $0.035 *$ & $0.046 *$ & 0.020 & $0.047^{*}$ & $0.107^{*}$ & $0.276^{*}$ & 0.023 \\
\hline Am-241 & 0.362 & 1.100 & 0.611 & 0.418 & 0.339 & 0.612 & 2.580 & 0.697 & 0.435 \\
\hline Nat-U & $0.264^{*}$ & $1.610^{*}$ & $0.082^{*}$ & $0.052^{*}$ & $0.211^{*}$ & $0.091^{*}$ & $0.190^{*}$ & $0.606^{*}$ & $0.041^{*}$ \\
\hline Nat-U $U^{\dagger}$ & 0.390 & 2.378 & 0.121 & 0.077 & 0.312 & 0.134 & 0.281 & 0.895 & 0.061 \\
\hline
\end{tabular}

(a) Locations are identified in Figure 4, except KAEV-09, which is an off-site sample taken from The Ohio State University Agriculture campus. 
TABLE 20. RADIOLOGICAL ANALYSES OF SEDIMENT

SAMPLES KING AVENUE SITE - 1994

\begin{tabular}{|c|c|c|}
\hline \multirow[b]{2}{*}{ Nuclide } & \multicolumn{2}{|c|}{ pCirg dry wt. (a) Avg. } \\
\hline & $\mathrm{KAED}-\mathrm{I}^{\mathrm{b}}$ & $\mathrm{KAED}-2^{(\mathrm{c})}$ \\
\hline Co-57 & $<0.060$ & $<0.060$ \\
\hline Co-60 & $<0.095$ & $<0.084$ \\
\hline $\mathrm{Sb}-125$ & $<0.243$ & $<0.231$ \\
\hline Cs-134 & $<0.069$ & $<0.078$ \\
\hline Cs-137 & 0.133 & $<0.355$ \\
\hline Eu-152 & $<0.177$ & $<0.177$ \\
\hline Eu-154 & $<0.118$ & $<0.125$ \\
\hline $\mathrm{Am}-241$ & $<0.652$ & $<0.585$ \\
\hline U-235 & $<0.524$ & $<0.531$ \\
\hline $\mathrm{U}-235^{\dagger}$ & $<24.486$ & $<24.813$ \\
\hline U-238 & $<1.500$ & $<1.340$ \\
\hline $\mathrm{U}-238^{\dagger}$ & $<4.505$ & $<4.024$ \\
\hline Nat-U & 2.910 & 3.930 \\
\hline Nat- $U^{\dagger}$ & 4.298 & 5.805 \\
\hline Th-228 & 0.590 & 0.900 \\
\hline Th-230 & 1.650 & 4.100 \\
\hline Th-232 & 0.570 & 1.150 \\
\hline
\end{tabular}

(a) No standards for radionuclides in sediment have been established.

(b) Located along the Olentangy River near the storm sewer outfall at the low-head dam.

(c) Located along the Olentangy River north of King Avenue and south of the Ohio State University campus.

$\dagger \mu \mathrm{g} / \mathrm{g}$ 
TABLE 21. RADIOLOGICAL ANALYSIS OF

OLENTANGY RIVER WATER SAMPLE

KING AVENUE SITE ${ }^{(a)}-1994$

\begin{tabular}{|c|c|}
\hline Nuclide & $\mathrm{KARW}-1 \quad\left(10^{-} \mu \mathrm{Cl} / \mathrm{ml}\right)^{\mathrm{b}}$ \\
\hline Gross $\alpha$ & $7.98 \pm 6.78$ \\
\hline Gross $\beta$ & $7.85 \pm 2.20$ \\
\hline Co-57 & $<1.73$ \\
\hline Co- 60 & $<1.61$ \\
\hline $\mathrm{Sb}-125$ & $<5.14$ \\
\hline Cs-134 & $<1.65$ \\
\hline Cs-137 & $<1.81$ \\
\hline $\mathrm{Eu}-152$ & $<5.13$ \\
\hline Eu-154 & $<3.63$ \\
\hline U-235 & 13.9 \\
\hline $\mathrm{U}-235^{\dagger}$ & $<0.650$ \\
\hline U-238 & $<40.7$ \\
\hline $\mathrm{U}-238^{\dagger}$ & $<0.122$ \\
\hline Am-241 & $<5.19$ \\
\hline Nat-U & 1.84 \\
\hline Nat- $U^{\dagger}$ & 0.0031 \\
\hline Th-228 & $<0.60$ \\
\hline Th-230 & $<0.34$ \\
\hline Th-232 & 0.27 \\
\hline
\end{tabular}

(a) Located north of the West Fifth Avenue bridge (Figure 4).

(b) A priori minimum detection limit is $6.5 \times 10^{-9} \mu \mathrm{Ci} / \mathrm{ml}$ for gross $\alpha$ and $4.8 \times 10^{-9} \mu \mathrm{Ci} / \mathrm{ml}$ for gross $\beta$

$+\mu \mathrm{g} / \mathrm{ml}$ 
TABLE 22. SUMMARY OF FISH TISSUE ANALYSES KING AVENUE SITE - 1994

\begin{tabular}{|c|c|c|c|}
\hline \multirow[b]{2}{*}{ Nuclide } & \multicolumn{3}{|c|}{$\begin{array}{l}\text { Olentangy River Samples' } \\
\text { (pCi/g raw weight) }\end{array}$} \\
\hline & Bottom Feeder & $\begin{array}{l}\text { Non-Bottom } \\
\text { Feeder }\end{array}$ & Average \\
\hline Co 57 & $<0.085$ & $<0.106$ & $<0.096$ \\
\hline Co. 60 & $<0.177$ & $<0.195$ & $<0.186$ \\
\hline $\mathrm{Sb}-125$ & $<0.019$ & $<0.443$ & $<0.445$ \\
\hline Cs-134 & $<0.446$ & $<0.168$ & $<0.177$ \\
\hline Cs-137. & $<0.187$ & $<0.148$ & $<0.148$ \\
\hline Eu- 152 & $<0.148$ & $<0.247$ & $<0.227$ \\
\hline Eu-154 & $<0.208$ & $<0.185$ & $<0.165$ \\
\hline U -235 & $<0.144$ & $<0.673$ & $<0.638$ \\
\hline U $-235^{t}$ & $<6.729$ & $<31.449$ & $<29.813$ \\
\hline U-238 & $<2.757$ & $<1.960$ & $<1.650$ \\
\hline U-238 & $<8.279$ & $<5.886$ & $<4.955$ \\
\hline Am-241 & $<0.375$ & $<0.778$ & $<0.577$ \\
\hline Nat-U & $<0.041$ & $<0.041$ & $<0.041$ \\
\hline Nat-U'? & $<0.028$ & $<0.061$ & $<0.061$ \\
\hline Th-228 & $<0.058$ & $<0.059$ & $<0.058$ \\
\hline $\operatorname{Th}-230$ & $<0.082$ & $<0.096$ & $<0.089$ \\
\hline $\operatorname{Th}-232$ & $<0.058$ & $<0.042$ & $<0.050$ \\
\hline
\end{tabular}

(a) Fish samples were collected north of the West Fifth Avenue bridge (Figure 4). $+\mu \mathrm{g} / \mathrm{g}$ 


\section{TABLE 23. INTEGRATED EXTERNAL BACKGROUND RADIATION MEASUREMENTS AT THE PROPERTY LINE \\ KING AVENUE SITE - 1994}

\begin{tabular}{|c|c|c|}
\hline TLD \# & Sector $\left.^{\circ}\right)$ & $\begin{array}{l}\text { Integrated TLD } \\
\text { Measurements in } \\
\text { rem }\end{array}$ \\
\hline 1 & East & $<0.030$ \\
\hline 2 & Northeast & $<0.030$ \\
\hline 3 & Northwest & $<0.030$ \\
\hline 4 & North & $<0.030$ \\
\hline 5 & North & $<0.030$ \\
\hline 6 & Northwest & $<0.030$ \\
\hline 7 & Northwest & $<0.030$ \\
\hline 8 & West & $<0.030$ \\
\hline 9 & West & $<0.030$ \\
\hline 10 & Southwest & $<0.030$ \\
\hline 11 & Southwest & $<0.030$ \\
\hline 12 & South & $<0.030$ \\
\hline 13 & South & $<0.030$ \\
\hline 14 & Southeast & $<0.030$ \\
\hline 15 & East & $<0.030$ \\
\hline
\end{tabular}

(a) Refer to Figure 9. 

TABLE 24. NON-RADIOLOGICAL WATER EFFLUENT ANALYSES
WEST JEFFERSON SITE-1994

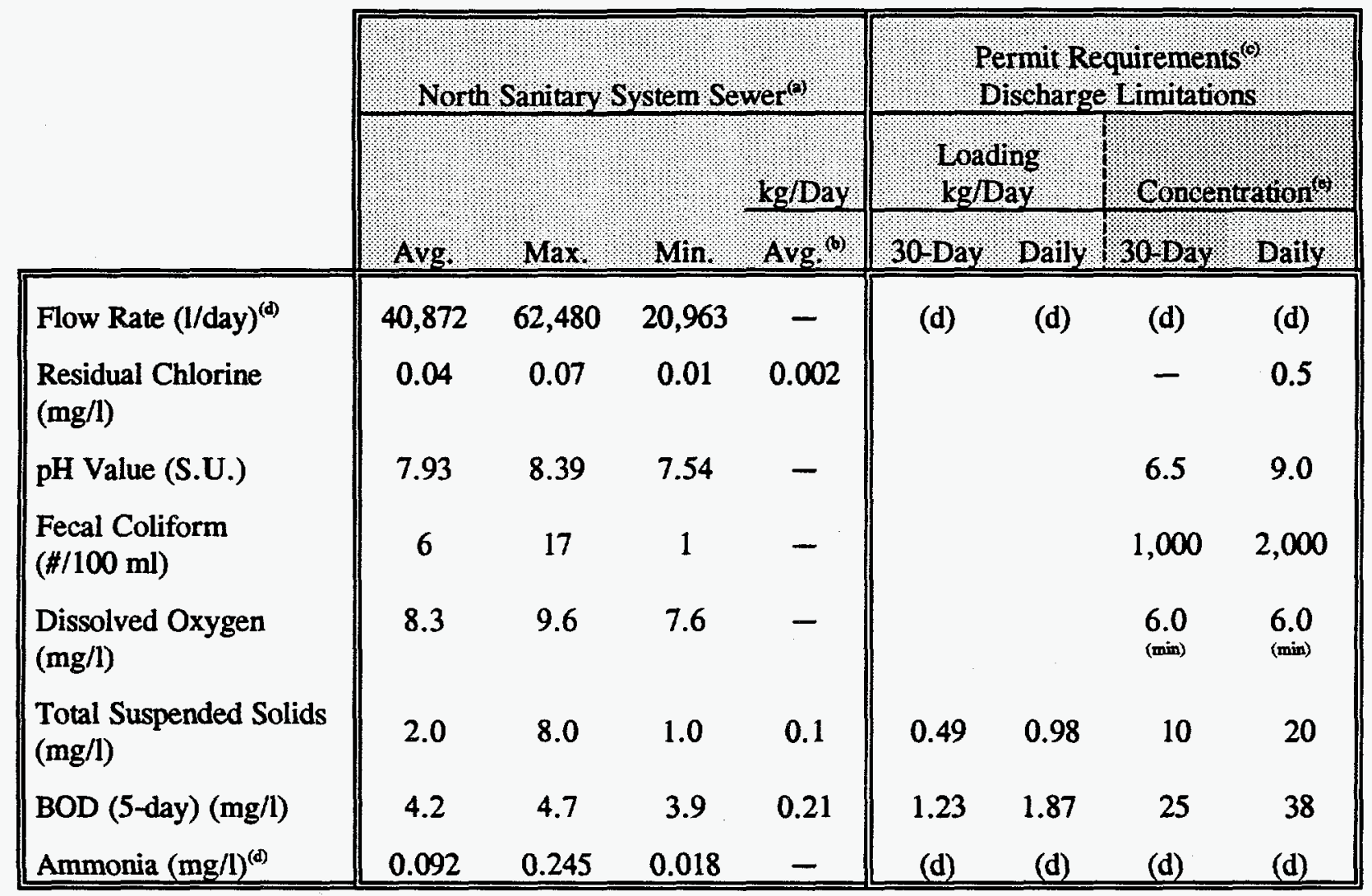

(a) Sampling site location is labeled 010 on Figure 5 (referred to as 001 in monthly NPDES reports). Includes discharge from Middle Area Sanitary System.

(b) Based on a flow rate of 0.013 MGD.

(c) Permit requirement discharge limitations based on NPDES Permit 4IN00004*DD.

(d) No restrictions for flow or ammonia under the NPDES Permit.

(e) Units specified in left column. 


\section{TABLE 25. NON-RADIOLOGICAL ANALYSES OF GROUNDWATER WEST JEFFERSON SITE - 1994}

\begin{tabular}{|c|c|c|c|}
\hline $\begin{array}{l}\text { Chemical } \\
\text { Parameter }\end{array}$ & Well $\mathrm{CO}^{\left({ }^{\circ}\right)}$ & Well $\operatorname{cog}^{(3)}$ & Well $\mathrm{Cl}^{\circ}{ }^{\circ}$ \\
\hline \multicolumn{4}{|c|}{ Total Metals (mg/l) } \\
\hline As & $<0.5$ & $<0.5$ & $<0.5$ \\
\hline $\mathrm{Ba}$ & 0.11 & 0.24 & 0.25 \\
\hline $\mathrm{Cd}$ & $<0.05$ & $<0.05$ & $<0.05$ \\
\hline $\mathrm{Cr}$ & $<0.01$ & $<0.1$ & $<0.1$ \\
\hline $\mathrm{Pb}$ & $<0.5$ & $<0.5$ & $<0.5$ \\
\hline $\mathrm{Hg}$ & $<0.05$ & $<0.005$ & $<0.005$ \\
\hline $\mathrm{Se}$ & $<0.5$ & $<0.5$ & $<0.5$ \\
\hline Ag & $<0.05$ & $<0.05$ & $\leq 0.05$ \\
\hline \multicolumn{4}{|c|}{ Pesticides and PCBs (mg/l) } \\
\hline 26 compounds & below detection limit & below detection limit & below detection limit \\
\hline \multicolumn{4}{|c|}{ Volatile Organics $(\mu \mathrm{g} / \mathrm{l})$} \\
\hline $\begin{array}{l}\text { Semivolatile Co } \\
65 \text { compounds }\end{array}$ & $\begin{array}{l}\text { apounds }(\mu \mathrm{g} / \mathrm{l}) \\
\text { below_detection limit }\end{array}$ & below detection limit & below detection limit \\
\hline $\begin{array}{l}\text { Oil \& Grease } \\
\text { (mg/l) }\end{array}$ & $\leq 1$ & $\leq 2$ & $\leq 1$ \\
\hline $\mathbf{p H}$ & 7.0 & 6.7 & 7.6 \\
\hline
\end{tabular}

(a) Locations are shown in Figure 10. 


\section{TABLE 26. SUMMARY OF ALPHA/BETA RADIOLOGICAL ANALYSES OF GROUNDWATER ${ }^{(\mathbf{a})}$ WEST JEFFERSON SITE - 1994}

\begin{tabular}{|c|c|c|c|c|c|c|c|}
\hline \multirow{3}{*}{$\frac{\text { Identification }}{\mathrm{JN}}$} & \multirow{3}{*}{$\begin{array}{c}\text { Number } \\
\text { Samples }\end{array}$} & \multicolumn{6}{|c|}{$\mathrm{pCi}^{\left({ }^{(b)}\right.}$} \\
\hline & & \multicolumn{3}{|c|}{ Gross $\alpha \pm 2$ sigma } & \multicolumn{3}{|c|}{ Gross $\beta \pm 2$ sigma } \\
\hline & & 3.02 & \pm & 6.22 & 4.71 & \pm & 2.95 \\
\hline $\mathrm{JM}$ & 2 & 0.44 & \pm & 4.95 & 4.65 & \pm & 2.94 \\
\hline JS & 2 & 1.64 & \pm & 5.38 & 6.70 & \pm & 3.07 \\
\hline $\mathrm{CO3}$ & 2 & 25.20 & \pm & 11.00 & 14.20 & \pm & 4.49 \\
\hline $\mathrm{C} 09$ & 2 & 25.20 & \pm & 13.80 & 46.90 & \pm & 7.06 \\
\hline $\mathrm{C} 16$ & 2 & 6.98 & \pm & 10.70 & 34.80 & \pm & 6.09 \\
\hline 101 & 2 & 36.80 & \pm & 21.90 & 40.30 & \pm & 6.93 \\
\hline 103 & 2 & 19.50 & \pm & 13.20 & 20.20 & \pm & 4.92 \\
\hline $110^{(c)}$ & 0 & UA & \pm & UA & UA & \pm & UA \\
\hline 118 & 2 & 8.32 & \pm & 10.20 & 18.50 & \pm & 4.74 \\
\hline 150 & 2 & 21.70 & \pm & 14.60 & 23.80 & \pm & 5.24 \\
\hline 155 & 2 & 3.65 & \pm & 8.75 & 11.60 & \pm & 4.24 \\
\hline 168 & 2 & 8.86 & \pm & 10.40 & 24.20 & \pm & 5.32 \\
\hline 172 & 2 & 13.20 & \pm & 11.20 & 32.80 & \pm & 5.88 \\
\hline 206 & 2 & 7.46 & \pm & 9.46 & 9.13 & \pm & 3.87 \\
\hline 306 & 2 & 13.40 & \pm & 12.50 & 10.50 & \pm & 4.14 \\
\hline 403 & 2 & 19.50 & \pm & 13.10 & 18.70 & \pm & 4.76 \\
\hline 506 & 2 & 14.20 & \pm & 13.20 & 18.30 & \pm & 4.94 \\
\hline 601 & 2 & 11.40 & \pm & 17.50 & 14.10 & \pm & 5.00 \\
\hline
\end{tabular}

(a) Locations are shown in Figures 10 and 11.

(b) Minimum detection limit (MDL): gross $\alpha: 1.0 \mathrm{pCi} / 1 /$ gross $\beta: 2.9 \mathrm{pCi} / 1$

(c) UA denotes no sample available, low water level 
TABLE 27. SUMMARY OF RADIOLOGICAL ANALYSES OF GROUNDWATER WEST JEFFERSON SITE-1994

volume $=1900 \mathrm{ml} 1 \times 10^{-9} \mu \mathrm{Ci} / \mathrm{ml}$

All values are less than MDA values except where indicated $(*)$

\begin{tabular}{|c|c|c|c|c|c|c|c|c|c|c|c|c|c|c|c|c|c|c|c|}
\hline \multirow[b]{2}{*}{ Nuclide } & \multicolumn{19}{|c|}{ Well Identification No. } \\
\hline & 101 & 103. & 110. & 118. & 150. & 15.5 & 168. & 172 & 206 . & 306 & 403 & 506 & 601 & $\mathrm{c}-03$ & $\mathrm{cc09}$ & 0.16 & IM:W & IN-W & JS:W \\
\hline Co-57 & 1.64 & 1.74 & UA & 1.38 & 2.27 & 1.45 & 2.14 & 1.72 & 1.79 & 1.44 & 1.50 & 2.25 & 1.82 & 1.50 & 2.42 & 1.48 & 1.49 & 1.46 & 2.33 \\
\hline $\mathrm{Co}-60$ & 2.19 & 1.56 & UA & 1.80 & 3.16 & 1.37 & 4.18 & 2.27 & 1.54 & 1.96 & 1.27 & 4.08 & 1.59 & 1.72 & 3.54 & 1.38 & 1.35 & 1.85 & 3.95 \\
\hline Sr-90 & $1.51^{*}$ & $1.52^{*}$ & UA & $0.62^{*}$ & 0.69 & $0.53^{*}$ & $7.26^{*}$ & $7.93^{*}$ & $0.35^{*}$ & $0.85^{*}$ & $1.64^{*}$ & $1.69 *$ & $0.32^{*}$ & $1.88 *$ & $11.50^{*}$ & $0.78^{*}$ & $0.10^{*}$ & $0.20^{*}$ & 0.00 \\
\hline$S b-125$ & 5.87 & 4.88 & UA & 4.967 & 7.76 & 4.22 & 9.06 & 6.27 & 5.09 & 5.12 & 4.42 & 9.09 & 4.99 & 4.91 & 8.12 & 4.38 & 4.53 & 4.99 & 9.25 \\
\hline Cs-134 & 2.02 & 1.59 & UA & 1.75 & 2.80 & 1.50 & 3.19 & 2.07 & 1.70 & 1.80 & 1.56 & 3.19 & 1.67 & 1.79 & 2.92 & 1.49 & 1.49 & 1.79 & 3.44 \\
\hline Cs-137 & 2.36 & 1.74 & UA & 1.89 & 2.99 & 1.49 & 3.54 & 2.27 & 1.74 & 1.95 & 1.52 & 3.58 & 1.72 & 1.96 & 3.52 & 1.55 & 1.60 & 1.97 & 3.48 \\
\hline Eu-152 & 4.72 & 4.98 & UA & 3.94 & 6.49 & 4.14 & 6.17 & 4.94 & 5.13 & 4.13 & 4.39 & 6.48 & 5.22 & 4.20 & 6.89 & 4.17 & 4.23 & 4.06 & 6.55 \\
\hline Eu-154 & 3.34 & 3.50 & UA & 2.81 & 4.49 & 2.90 & 4.33 & 3.46 & 3.59 & 2.96 & 3.03 & 4.52 & 3.67 & 3.00 & 4.83 & 2.88 & 2.93 & 2.91 & 4.60 \\
\hline U-235 & 13.20 & 13.70 & UA & 11.80 & 16.50 & 11.20 & 17.20 & 13.80 & 14.0 & 12.10 & 11.60 & 17.30 & 14.10 & 12.30 & 16.60 & 11.40 & 11.50 & 12.10 & 17.30 \\
\hline U-235 ${ }^{+}$ & 0.62 & 0.64 & UA & 0.51 & 0.55 & 0.52 & 0.80 & 0.64 & 0.65 & 0.57 & 0.54 & 0.81 & 0.66 & 0.52 & 0.78 & 0.53 & 0.54 & 0.52 & 0.81 \\
\hline U-238 & 41.70 & $140.0^{*}$ & UA & 41.30 & 48.40 & 38.70 & 41.80 & 43.30 & $257.0^{*}$ & 43.20 & 39.80 & 42.60 & 29.20 & 42.30 & 49.40 & 25.40 & 40.20 & 42.00 & 42.10 \\
\hline U-238 ${ }^{+}$ & 0.13 & 0.42 & $\mathrm{UA}_{\mathrm{A}}$ & 0.12 & 0.15 & 0.12 & 0.13 & 0.13 & 0.77 & 0.13 & 0.12 & 0.13 & 0.09 & 0.13 & 0.15 & 0.08 & 0.12 & 0.13 & 0.13 \\
\hline Pu-238 & $0.03 *$ & $0.07 *$ & UA & $0.03^{*}$ & $0.04 *$ & $0.19 *$ & $0.33^{*}$ & $0.40^{*}$ & $0.13^{*}$ & $0.03 *$ & $0.03^{*}$ & $0.03^{*}$ & $0.07^{*}$ & $0.36 *$ & $0.01^{*}$ & $0.12^{*}$ & NR & NR & NR \\
\hline Pu-239 & $0.16^{*}$ & $0.07 *$ & $\mathrm{UA}_{\mathrm{A}}$ & $0.10^{*}$ & $0.04^{*}$ & $0.19 *$ & $0.24^{*}$ & $0.28^{*}$ & $0.09^{*}$ & $0.03 *$ & $0.10^{*}$ & $0.14^{*}$ & $0.09 *$ & $0.17^{*}$ & $0.92^{*}$ & $0.09 *$ & NR & NR & NR \\
\hline Am-241 & 4.66 & 4.87 & UA & 4.32 & 14.20 & 4.81 & 12.00 & 4.79 & 5.06 & 4.42 & 4.95 & 11.60 & 5.16 & 4.34 & 15.20 & 4.82 & 4.97 & 4.54 & 11.80 \\
\hline Nat-U & $1.39 *$ & $1.55^{*}$ & $\mathrm{UA}_{\mathrm{A}}$ & $3.71^{*}$ & $1.42^{*}$ & $4.37 *$ & $2.58 *$ & $3.24^{*}$ & $2.44^{*}$ & $4.89 *$ & $3.25^{*}$ & $3.69 *$ & $3.07 *$ & $4.27^{*}$ & $3.41^{*}$ & $1.63^{*}$ & NR & NR & NR \\
\hline Nat- $\mathbf{U}^{\dagger}$ & 0.002 & 0.002 & UA & 0.005 & 0.002 & 0.006 & 0.004 & 0.005 & 0.004 & 0.007 & 0.005 & 0.005 & 0.005 & 0.006 & 0.005 & 0.002 & NR & NR & NR \\
\hline
\end{tabular}

(a) Locations are shown in Figures 9 and 10.

$\dagger \mu \mathrm{g} / \mathrm{ml}$

UA denotes no sample available, low water level

NR denotes data not returned from laboratory 
TABLE 28. ARITHMETIC AVERAGE WIND SPEEDS (m/sec) AND FREQUENCY (WIND TOWARDS)

\begin{tabular}{|c|c|c|c|c|c|c|c|c|}
\hline \multirow[b]{2}{*}{ Dir } & \multicolumn{6}{|c|}{ Pasquill Stability Class } & \multirow[b]{2}{*}{ G } & \multirow[b]{2}{*}{ Frequency } \\
\hline & A. & B & C & D & E. & F & & \\
\hline$N$ & 1.467 & 2.317 & 3.320 & 4.564 & 2.197 & 0.000 & 0.000 & 0.111 \\
\hline NNW & 1.525 & 2.463 & 3.228 & 4.162 & 2.083 & 0.000 & 0.000 & 0.064 \\
\hline NW & 1.588 & 2.115 & 3.452 & 4.166 & 2.058 & 0.000 & 0.000 & 0.060 \\
\hline WNW & 0.997 & 2.414 & 3.505 & 4.015 & 1.924 & 0.000 & 0.000 & 0.059 \\
\hline W & 1.540 & 2.230 & 3.421 & 3.950 & 1.875 & 0.000 & 0.000 & 0.050 \\
\hline WSW & 1.467 & 2.634 & 3.611 & 4.227 & 1.924 & 0.000 & 0.000 & 0.045 \\
\hline SW & 1.456 & 2.449 & 3.697 & 4.026 & 1.870 & 0.000 & 0.000 & 0.042 \\
\hline SSW & 1.372 & 2.488 & 3.700 & 4.212 & 1.918 & 0.000 & 0.000 & 0.047 \\
\hline $\mathbf{S}$ & 1.533 & 2.292 & 3.456 & 4.334 & 1.861 & 0.000 & 0.000 & 0.078 \\
\hline SSE & 1.243 & 2.363 & 3.615 & 4.945 & 2.137 & 0.000 & 0.000 & 0.066 \\
\hline SE & 1.413 & 2.490 & 3.766 & 5.271 & 2.416 & 0.000 & 0.000 & 0.055 \\
\hline ESE & 1.560 & 2.376 & 4.272 & 5.803 & 2.647 & 0.000 & 0.000 & 0.063 \\
\hline $\mathrm{E}$ & 1.513 & 2.226 & 4.532 & 5.975 & 2.812 & 0.000 & 0.000 & 0.064 \\
\hline ENE & 1.543 & 2.319 & 4.400 & 6.400 & 3.106 & 0.000 & 0.000 & 0.049 \\
\hline $\mathrm{NE}$ & 1.420 & 2.474 & 4.431 & 6.138 & 2.870 & 0.000 & 0.000 & 0.062 \\
\hline NNE & 1.447 & 2.692 & 4.059 & 5.394 & 2.517 & 0.000 & 0.000 & 0.086 \\
\hline
\end{tabular}


TABLE 29. MINIMUM X/Q DISPERSION VALUES AT THE WEST JEFFERSON SITE FROM JN-1 AND

JN-2 STACKS

\begin{tabular}{|c|c|}
\hline Nueliade & $\mathrm{x} / 0$ \\
\hline $\mathrm{Co}-57$ & $6.10 \times 10^{-6}$ \\
\hline Co-60 & $6.56 \times 10^{-6}$ \\
\hline Sr-90 & $6.27 \times 10^{-6}$ \\
\hline $\mathrm{Sb}-125$ & $5.90 \times 10^{-6}$ \\
\hline $\mathrm{Cs}-134$ & $6.22 \times 10^{-6}$ \\
\hline $\mathrm{Cs}-137$ & $6.27 \times 10^{-6}$ \\
\hline Eu-152 & $6.20 \times 10^{-6}$ \\
\hline Eu-154 & $6.30 \times 10^{-6}$ \\
\hline U-235 & $6.17 \times 10^{-6}$ \\
\hline U-238 & $5.91 \times 10^{-6}$ \\
\hline $\mathrm{Pu}-238$ & $6.13 \times 10^{-6}$ \\
\hline $\mathrm{Pu}-239$ & $6.99 \times 10^{-6}$ \\
\hline Am-241 & $6.11 \times 10^{-6}$ \\
\hline
\end{tabular}

These minimums occur at the boundary of the Battelle property on the north side of the site. 


\section{TABLE 30. DOE-EML QUALITY ASSESSMENT PROGRAM RESULTS FOR BATTELLE RADIOANALYTICAL LABORATORY (2ND HALF-1994)}

\begin{tabular}{|c|c|c|c|c|c|c|c|c|}
\hline $\begin{array}{l}\text { Tost } \\
\text { No. }\end{array}$ & $\begin{array}{l}\text { Radio- } \\
\text { Nuelido }\end{array}$ & $\begin{array}{c}\text { Reportod } \\
\text { Valuo }\end{array}$ & Error & $\underset{\text { Valua }}{\text { EML }}$ & $\underset{\text { Error }}{\text { EML }}$ & $\frac{\text { Beported }}{\text { EML }}$ & $\begin{array}{l}\text { Ratio } \\
\text { Error }\end{array}$ & Evaluation \\
\hline \multicolumn{9}{|l|}{ Matrix: } \\
\hline $\begin{array}{l}1 \\
1 \\
1 \\
1 \\
1 \\
1 \\
1 \\
1 \\
1 \\
1 \\
1 \\
1 \\
1 \\
1\end{array}$ & $\begin{array}{c}\text { AM241 } \\
\text { CE144 } \\
\text { CO } 57 \\
\text { CO 60 } \\
\text { CS134 } \\
\text { CS137 } \\
\text { MN 54 } \\
\text { PU238 } \\
\text { PU239 } \\
\text { RU106 } \\
\text { SB125 } \\
\text { SR 90 } \\
\text { U } 234 \\
\text { U } 238\end{array}$ & $\begin{array}{r}0.160 \\
81.100 \\
13.000 \\
10.000 \\
24.600 \\
11.700 \\
7.280 \\
0.088 \\
0.740 \\
5.100 \\
28.000 \\
1.230 \\
0.110 \\
0.095\end{array}$ & $\begin{array}{l}0.110 \\
5.700 \\
0.900 \\
0.700 \\
1.700 \\
0.800 \\
0.410 \\
0.014 \\
0.090 \\
1.200 \\
2.000 \\
0.190 \\
0.030 \\
0.023\end{array}$ & $\begin{array}{r}0.212 \\
81.400 \\
12.900 \\
10.200 \\
21.100 \\
10.400 \\
6.690 \\
0.072 \\
0.648 \\
5.750 \\
25.300 \\
1.330 \\
0.112 \\
0.112\end{array}$ & $\begin{array}{l}0.007 \\
1.350 \\
0.308 \\
0.281 \\
0.319 \\
0.298 \\
0.238 \\
0.004 \\
0.027 \\
0.951 \\
0.702 \\
0.049 \\
0.004 \\
0.003\end{array}$ & $\begin{array}{l}0.76 \\
1.00 \\
1.01 \\
0.98 \\
1.17 \\
1.13 \\
1.09 \\
1.22 \\
1.14 \\
0.89 \\
1.11 \\
0.93 \\
0.98 \\
0.85\end{array}$ & $\begin{array}{l}0.52 \\
0.07 \\
0.07 \\
0.07 \\
0.08 \\
0.08 \\
0.07 \\
0.21 \\
0.15 \\
0.26 \\
0.08 \\
0.15 \\
0.27 \\
0.21\end{array}$ & $\begin{array}{l}W \\
A \\
A \\
A \\
W \\
A \\
A \\
A \\
W \\
A \\
A \\
A \\
A \\
A \\
W\end{array}$ \\
\hline \multicolumn{9}{|l|}{ Matrix: } \\
\hline $\begin{array}{l}1 \\
1 \\
1 \\
1 \\
1 \\
1\end{array}$ & $\begin{array}{r}\text { CS137 } \\
K 40 \\
\text { PU238 } \\
\text { PU239 } \\
U 234 \\
U 238\end{array}$ & $\begin{array}{r}238.000 \\
313.000 \\
0.310 \\
7.400 \\
26.600 \\
26.600\end{array}$ & $\begin{array}{r}17.000 \\
25.000 \\
0.310 \\
1.500 \\
5.200 \\
5.200\end{array}$ & $\begin{array}{r}280.000 \\
428.000 \\
0.310 \\
7.780 \\
32.600 \\
33.000\end{array}$ & $\begin{array}{r}4.870 \\
34.500 \\
0.183 \\
0.350 \\
0.779 \\
2.410\end{array}$ & $\begin{array}{l}0.85 \\
0.73 \\
1.00 \\
0.95 \\
0.82 \\
0.81\end{array}$ & $\begin{array}{l}0.06 \\
0.08 \\
1.16 \\
0.20 \\
0.16 \\
0.17\end{array}$ & $\begin{array}{l}A \\
W \\
A \\
A \\
A \\
A\end{array}$ \\
\hline \multicolumn{9}{|l|}{ Matrix: } \\
\hline $\begin{array}{l}1 \\
1 \\
1 \\
1 \\
1 \\
1 \\
1\end{array}$ & $\begin{array}{r}\text { AM241 } \\
\text { CO 60 } \\
\text { CS137 } \\
\text { K 40 } \\
\text { PU238 } \\
\text { PU239 } \\
\text { SR 90 }\end{array}$ & $\begin{array}{r}0.630 \\
8.800 \\
127.000 \\
665.000 \\
0.140 \\
1.440 \\
420.000\end{array}$ & $\begin{array}{r}0.380 \\
0.600 \\
10.000 \\
30.000 \\
0.040 \\
0.150 \\
35.000\end{array}$ & $\begin{array}{r}0.816 \\
10.700 \\
148.000 \\
808.000 \\
0.092 \\
1.250 \\
535.000\end{array}$ & $\begin{array}{r}0.074 \\
0.287 \\
2.600 \\
12.800 \\
0.026 \\
0.150 \\
121.000\end{array}$ & $\begin{array}{l}0.77 \\
0.82 \\
0.86 \\
0.82 \\
1.53 \\
1.15 \\
0.79\end{array}$ & $\begin{array}{l}0.47 \\
0.06 \\
0.07 \\
0.04 \\
0.61 \\
0.18 \\
0.19\end{array}$ & $\begin{array}{l}A \\
W \\
A \\
A \\
W \\
A \\
A\end{array}$ \\
\hline \multicolumn{9}{|l|}{ Matrix: } \\
\hline $\begin{array}{l}1 \\
1 \\
1 \\
1 \\
1 \\
1 \\
1 \\
1 \\
1 \\
1 \\
1\end{array}$ & $\begin{array}{c}\text { AM241 } \\
\text { CE144 } \\
\text { CO 60 } \\
\text { CS134 } \\
\text { CS137 } \\
\text { MN } 54 \\
\text { PU238 } \\
\text { PU239 } \\
\text { SA 90 } \\
\text { U } 234 \\
\text { U } 238\end{array}$ & $\begin{array}{r}0.930 \\
436.000 \\
333.000 \\
54.000 \\
50.400 \\
100.000 \\
1.080 \\
0.600 \\
27.800 \\
1.120 \\
1.060\end{array}$ & $\begin{array}{r}0.190 \\
31.000 \\
23.000 \\
3.700 \\
3.500 \\
7.000 \\
0.150 \\
0.060 \\
8.300 \\
0.120 \\
0.110\end{array}$ & $\begin{array}{r}1.010 \\
491.000 \\
317.000 \\
53.000 \\
46.600 \\
108.000 \\
1.060 \\
0.602 \\
68.600 \\
1.110 \\
1.110\end{array}$ & $\begin{array}{l}0.056 \\
4.440 \\
6.120 \\
1.230 \\
1.070 \\
2.000 \\
0.095 \\
0.063 \\
3.250 \\
0.013 \\
0.047\end{array}$ & $\begin{array}{l}0.92 \\
0.89 \\
1.05 \\
1.02 \\
1.08 \\
0.93 \\
1.02 \\
1.00 \\
0.41 \\
1.01 \\
0.96\end{array}$ & $\begin{array}{l}0.20 \\
0.06 \\
0.08 \\
0.07 \\
0.08 \\
0.07 \\
0.17 \\
0.15 \\
0.12 \\
0.11 \\
0.11\end{array}$ & $\begin{array}{l}A \\
A \\
A \\
A \\
A \\
A \\
A \\
A \\
N \\
A \\
A\end{array}$ \\
\hline
\end{tabular}

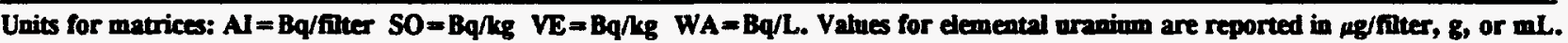
Evaluation: $A=$ Acceptable, $W=$ Acceptable with Warning, $N=$ Not Acceptable . 


\section{Appendix C}

\section{Environmental Report}

External Distribution List 


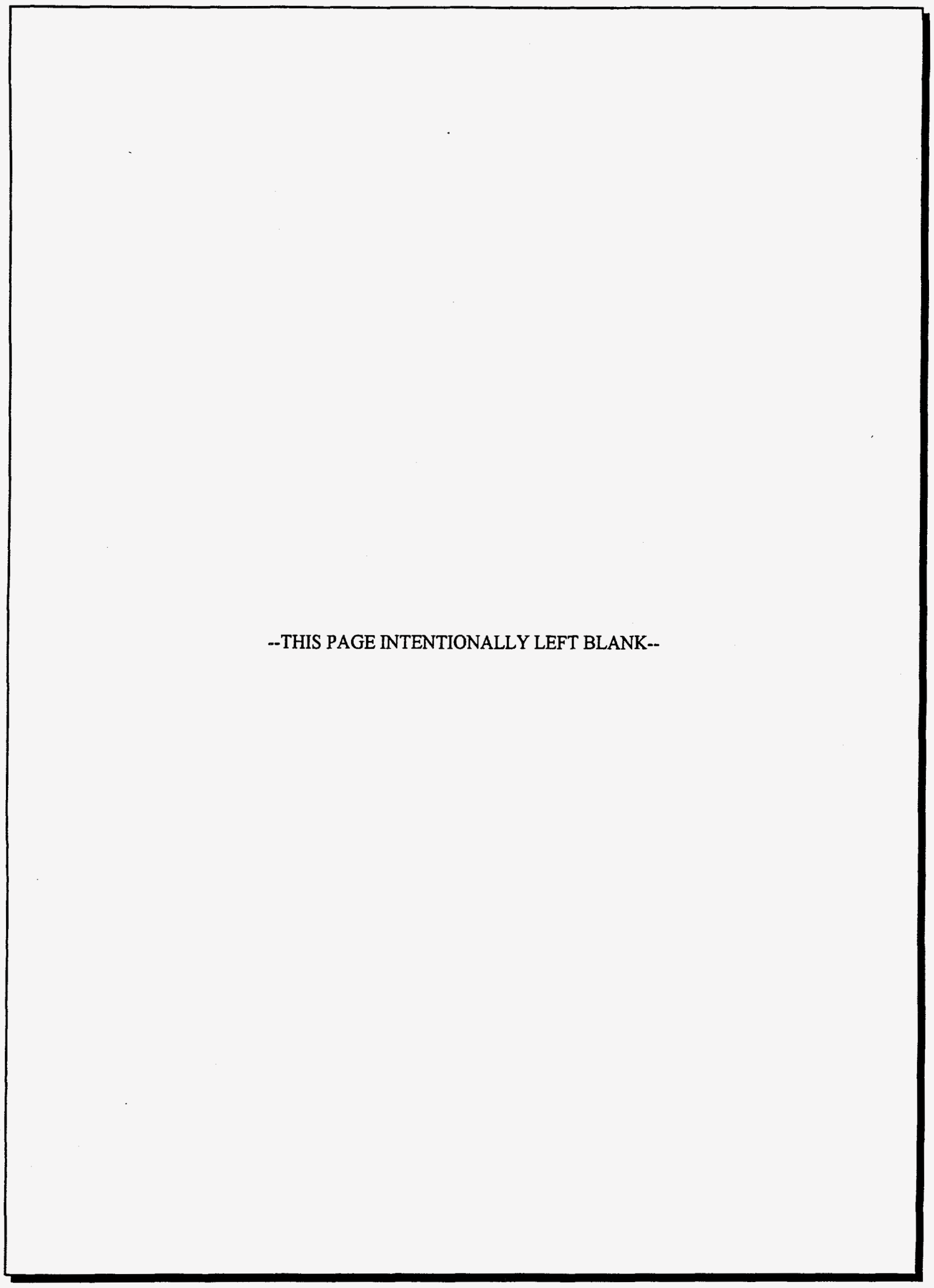




\section{Appendix C \\ Environmental Report External Distribution List}

Battelle Pacific Northwest Laboratories Battelle Boulevard

Richland, Washington 99352

Lois A. Holmes, Manager

Communications

K1-29

Columbus Health Department,

City of Columbus

181 Washington Blvd

Columbus, OH 43215

Michael Pompili

Assistant Health Commissioner

Environmental Health

Fermi National Acceleration Laboratory P.O. Box 500

Batavia, Illinois 60410

Dr. J. Donald Cossairt

Senior Environmental Protection Officer

Madison County Health Department

13 North Oak Street

London, OH 43140

B. Scott Wilson, Director

Environmental Health

Dr. James Herman

Health Commissioner

Ohio Department of Health

P.O. Box 118

Columbus, OH 43266-0118

Robert Owen, Chief

Bureau of Radiological Health
Ohio Environmental Protection Agency 1800 Watermark Drive

Columbus, OH 43216-0149

Donald R. Schregardus

Director

Linda Welch, Chief

Division of Hazardous Waste Mgmt

Jenny Tiell, Deputy Director

Waste Programs

John Sadzewicz, Chief

Division of Drinking \& Ground Waters

Robert Rothwell, Chief

Division of Water Pollution Control

Public Utilities Commission

180 East Broad Street

Columbus, Ohio 43216-0573

Ron Yerian

Ohio Power Siting Board

U.S. Department of Energy

1000 Independence Avenue

Washington, D.C. 20585

Mr. Raymond Pelletier, Director

Office of Environmental Guidance

EH-23

Mr. Michael A. Kirkpatrick, Director

Office of Environmental Audits

EH-24

Mr. Carl Bauer, Director

Idaho \& Chicago Programs Division

EM-441 
U.S. Department of Energy

Chicago Operations and Regional Office

9800 South Cass Avenue

Argonne, Illinois 60439

Mr. Fred Sienko, Branch Chief

Contracts Division

\section{U.S. Department of Energy}

505 King Avenue, A-495

Columbus, Ohio 43201

Mr. James W. Thomas

Project Manager

\section{U.S. Environmental Protection Agency}

77 West Jackson Blvd.

Chicago, IL 60604

Mr. David Kee, Director

Air and Radiation Division

(SAR26) Mail Stop A-18J
U.S. Environmental Protection Agency 401 M Street SW

Washington, D.C. 20460

Mr. Terrance A. McLaughin, Director

Waste Standards \& Risk Assessments Branch

Office of Air and Radiation

Mail Stop ANR-460

U.S. Nuclear Regulatory Commission

Region III Office

801 Warrenville Road

Lyle, Illinois 60532

Mr. John B. Martin, Administrator

U.S. Nuclear Regulatory Commission

Washington, D.C. 20555

Robert Pierson, Chief (3)

Advanced Fuel and Spent Fuel Licensing Branch

Mail Stop 6H3

Division of Fuel Cycle \& Material Safety 